\title{
Measures of job quality in Morocco: Creating a composite index [Arabic]
}

Touhami Abdelkhalek

Aziz Ajbilou

Mohamed Benkassmi

Follow this and additional works at: https://knowledgecommons.popcouncil.org/departments_sbsr-pgy

Part of the Demography, Population, and Ecology Commons, Family, Life Course, and Society Commons, International Public Health Commons, Medicine and Health Commons, and the Work, Economy and Organizations Commons

How does access to this work benefit you? Let us know!

\section{Recommended Citation}

Abdelkhalek, Touhami, Aziz Ajbilou, and Mohamed Benkassmi. 2009. "Measures of job quality in Morocco: Creating a composite index [Arabic]," Gender and Work in the MENA Region Working Paper no. 5. Cairo: Population Council. 


$$
\text { أغسدار رقم } 11
$$

النوع والعمل في منطقة الثرق الأوسط وشمال افريقيا

$$
\text { سلسلة أوراق بحثية }
$$

الققر ونوعية العمل وديناميكيات سوق العل

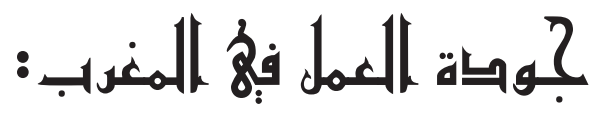

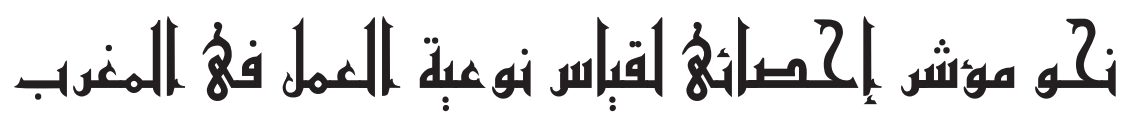

التهامي عبد الخالق، عزيز أجبيلو، محد بنقاسي 

مقاييس جودة العمل في المغرب: نحو تاسيس مؤشر شامل مركب

$$
\begin{aligned}
& \text { التهامي عبد الخالق' } \\
& \text { عزيز أجبيلون } \\
& \text { محمد بن كاسي" اليني" } \\
& \text { يوليو 9... }
\end{aligned}
$$

$$
\text { المقدميات }
$$

r- أبعاد ومؤشرات جود مة العمل: تقديم لمختلف الدراسات

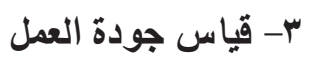$$
\text { r-1 - ب اعتبار ات منهجية }
$$

r-Y هدف مقاربة الوسيط في مقاربة جودة العمل צ-r-r مساهمة التصنيف التسلسلي التصاعدي مداري

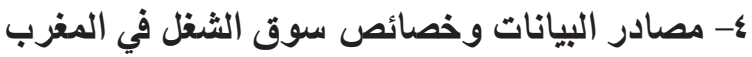
ع-1 إحصائيات الثغل في المغرب النيان

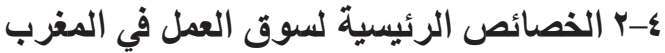

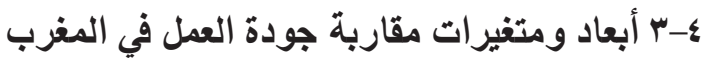
هـ جودة العمل في المغرب: جوانب مختلفة ه- هوض الخصائص الوصفية لقاعدة البيانات المستخدمة ه-Y الـMCA و إنشاء مؤشر جودة العمل

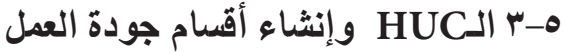

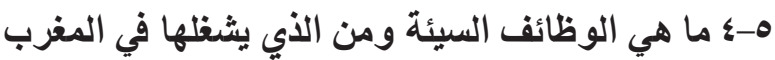

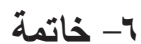

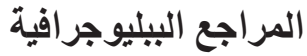

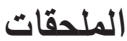

'باحث مدرس في INSAE، BP TIV ، برونج الرباط، الرباط، المغرب. بريد إليكتروني: Abdelkhalek_touchami@yahoo.fr

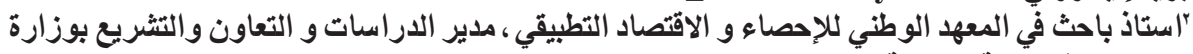

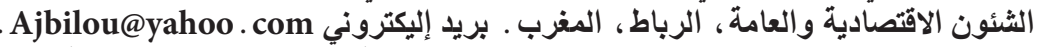

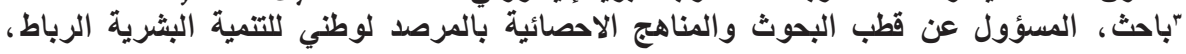
المغرب. بريد إليكتروني: Benkassmi@gmail.com 


\section{المقدمة:}

خلال السنو ات الأخيرة ، اهتمت العديد من الدول و المنظمات الدولية بما فيها منظمة العمل

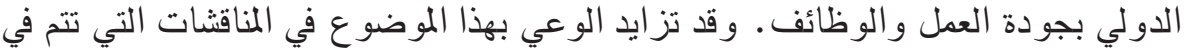

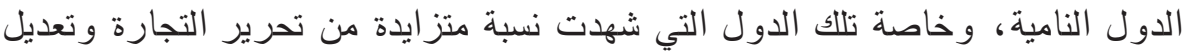

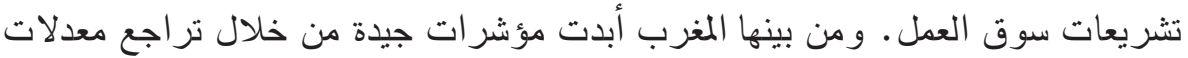

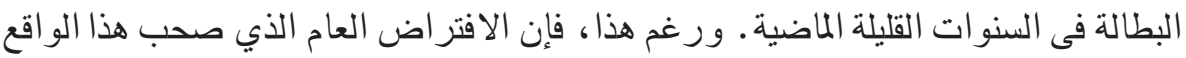

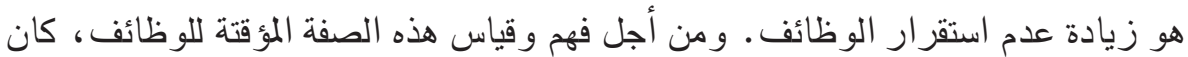

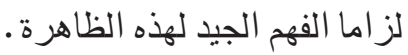

وفي هذا الثأن ، حددت منظمة العمل الدولية ما المقصود بـه العمل اللائق «ـ ـ اعتماد

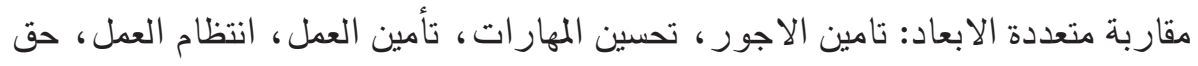

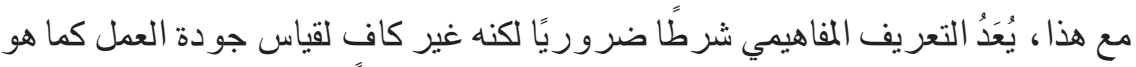

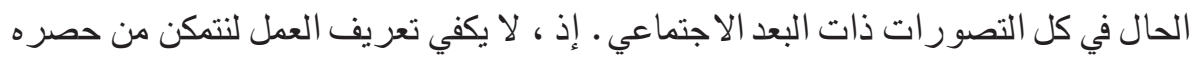

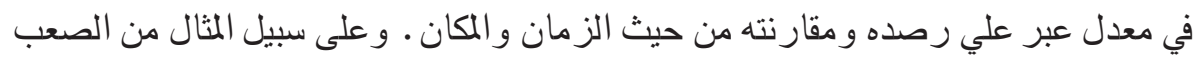

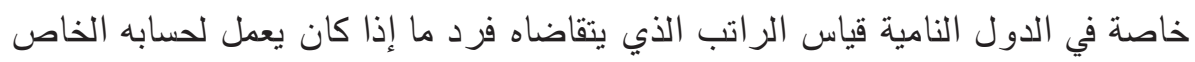

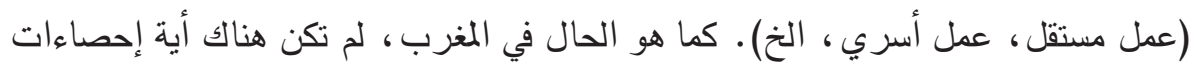

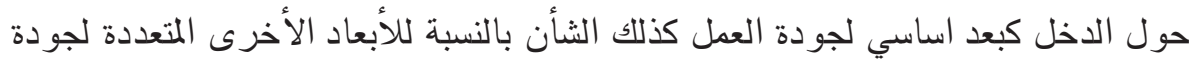
العمل.

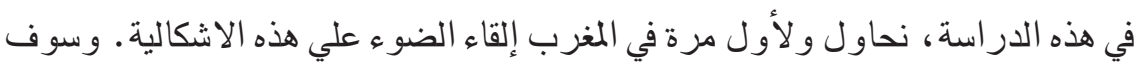

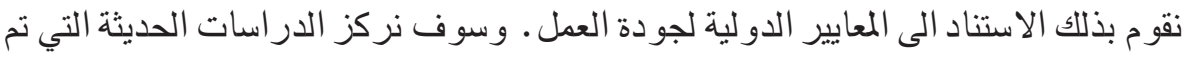

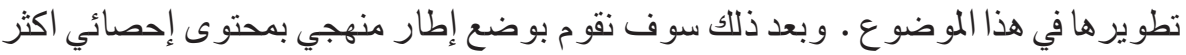

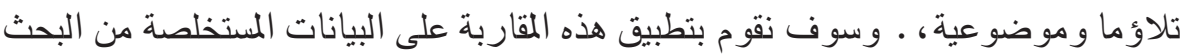

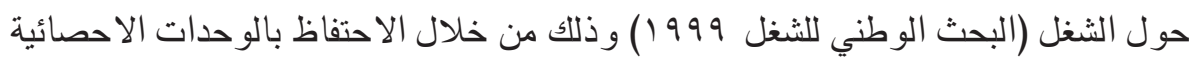

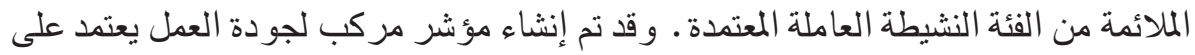

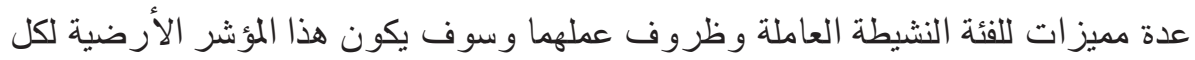
الاستنتاجات في هذا المجال .

والقسم الثاني من هذا النص ينطرق بصفة مختصرة للاراسة حول جودة العمل. 
وخصصنا القسم الثالث للأساس النظري للمقاربة المتعدد الأبعاد لمقترحة لقياس جودة العمل

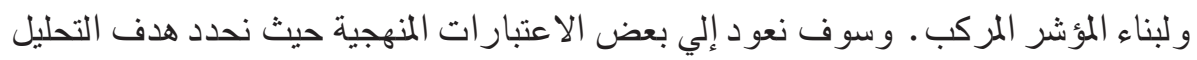

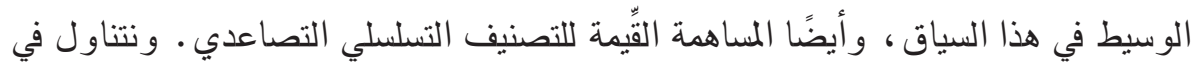

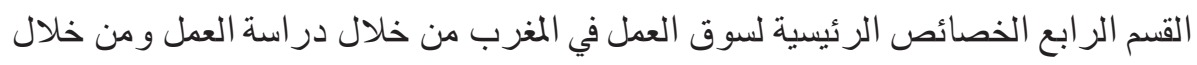

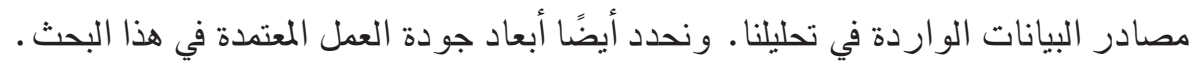

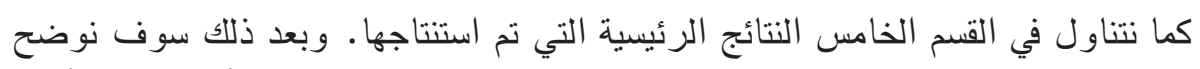
بعض عناصر جودة العمل في المغرب، من خلال خصائص متعددة. ـ ويأتي القسم الأخير

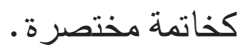

\section{r- أبعاد ومؤشرات جودة العمل: مراجعة الدراسات}

في هذا القسم، سوف نعرض باختصار الأبعاد التي تم اختيارها في الدراسات المماثلة

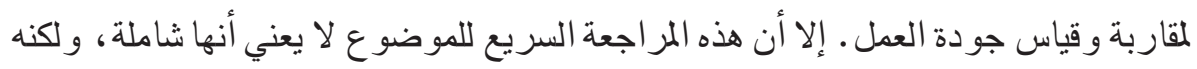

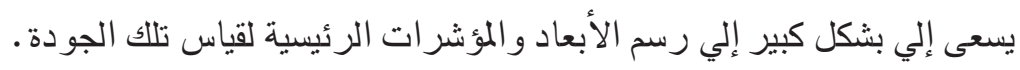

من الواضح أن جودة العمل كموضوع متعددة الأبعاد يحيلُ إلي ترابط العديد من

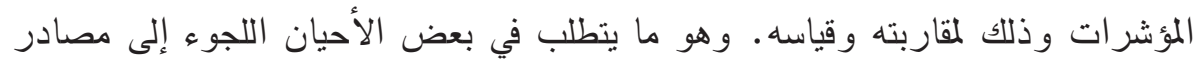

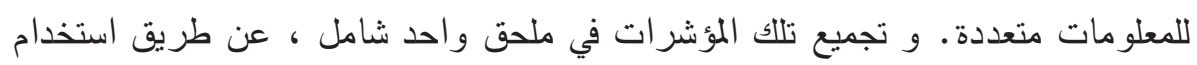

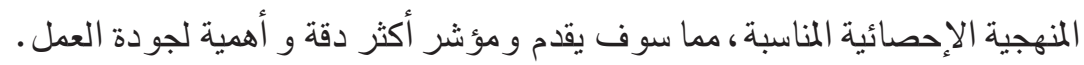

ويشير عدد من الدراسات التي أجريت على جودة العمل إلى ما أنجزته منظمة العمل

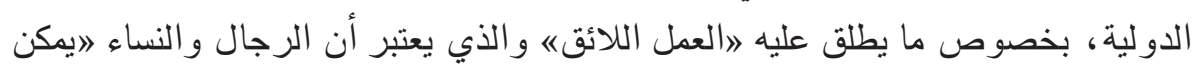

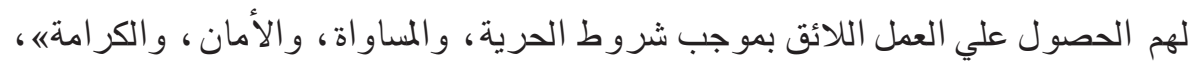

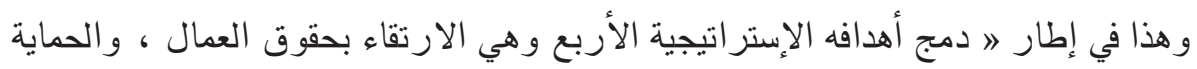

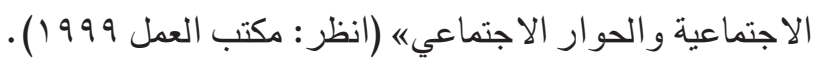

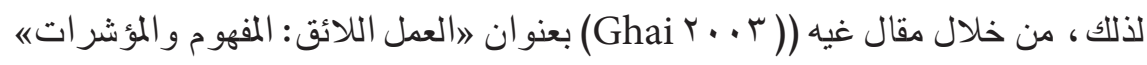

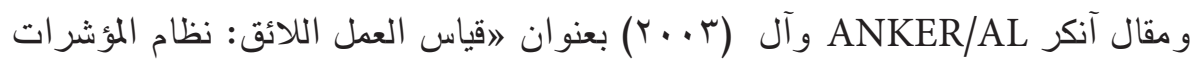

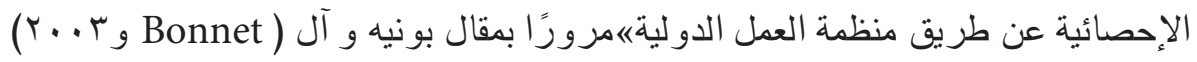

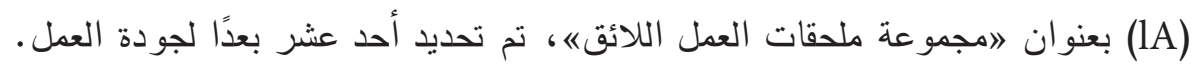

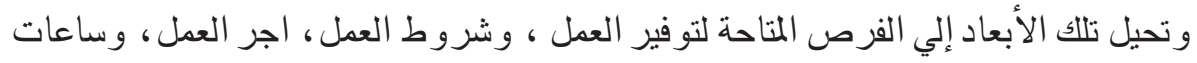

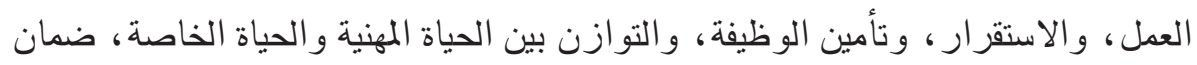




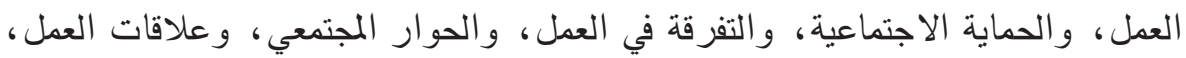

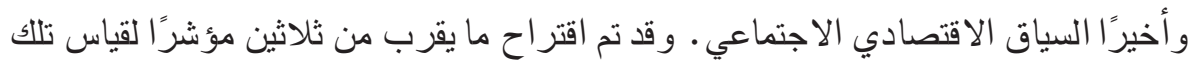

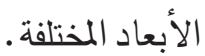

أجر يت كذلك بعض الأبحاث (لفائدة منظمة العمل الدولية بالتحديد)في نفس الإطار و من

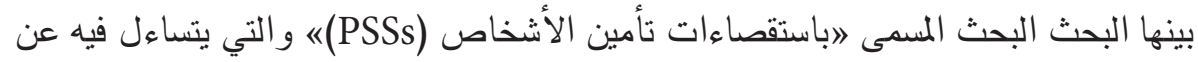

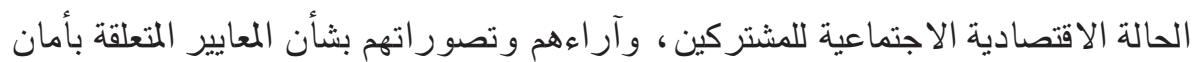

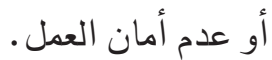

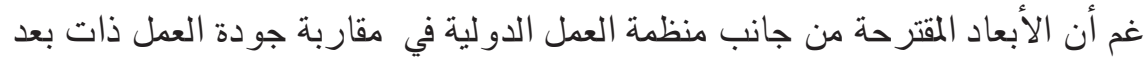

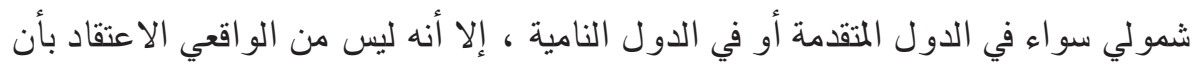

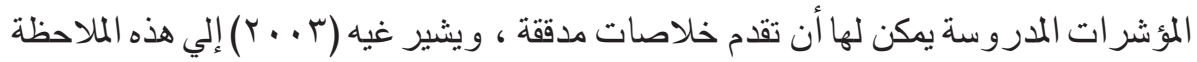

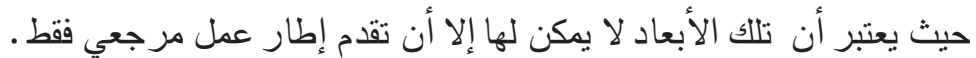

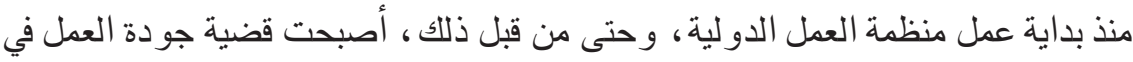
كل أنحاء العالم، موضوعًا في العديد من السياسات في الدول المتقدمة أكثر منها النامية.

ففي اوربا مثلا، ركز عدد من المؤتمرات علي هذا التساؤل مثل ( مؤتمرلثبونة

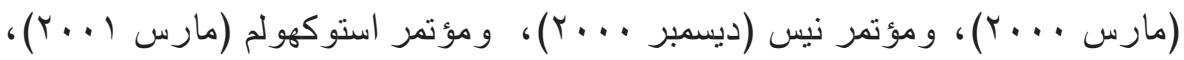

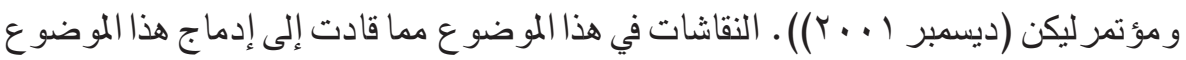

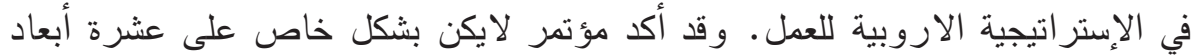

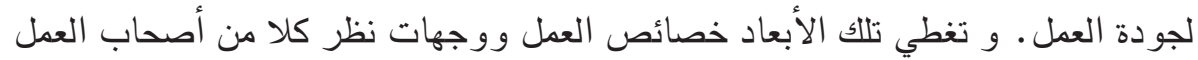

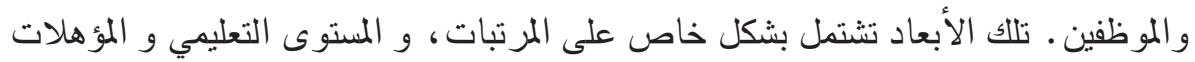

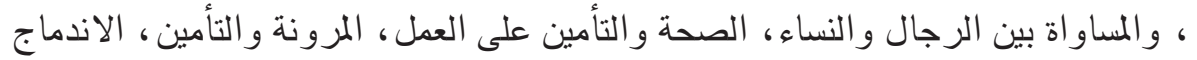

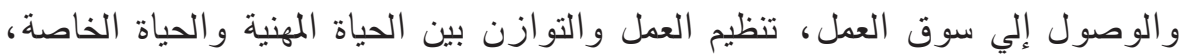

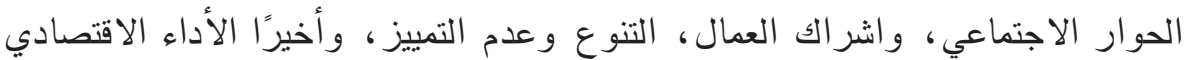

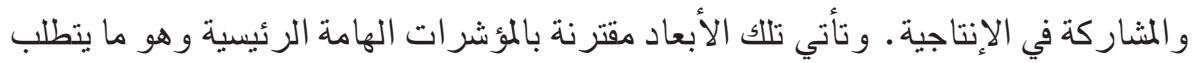
توفير مصادر إحصائية.

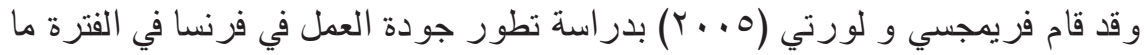

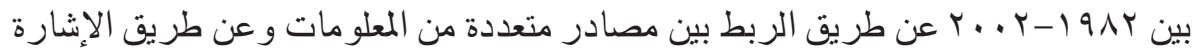

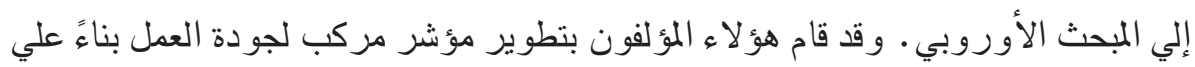




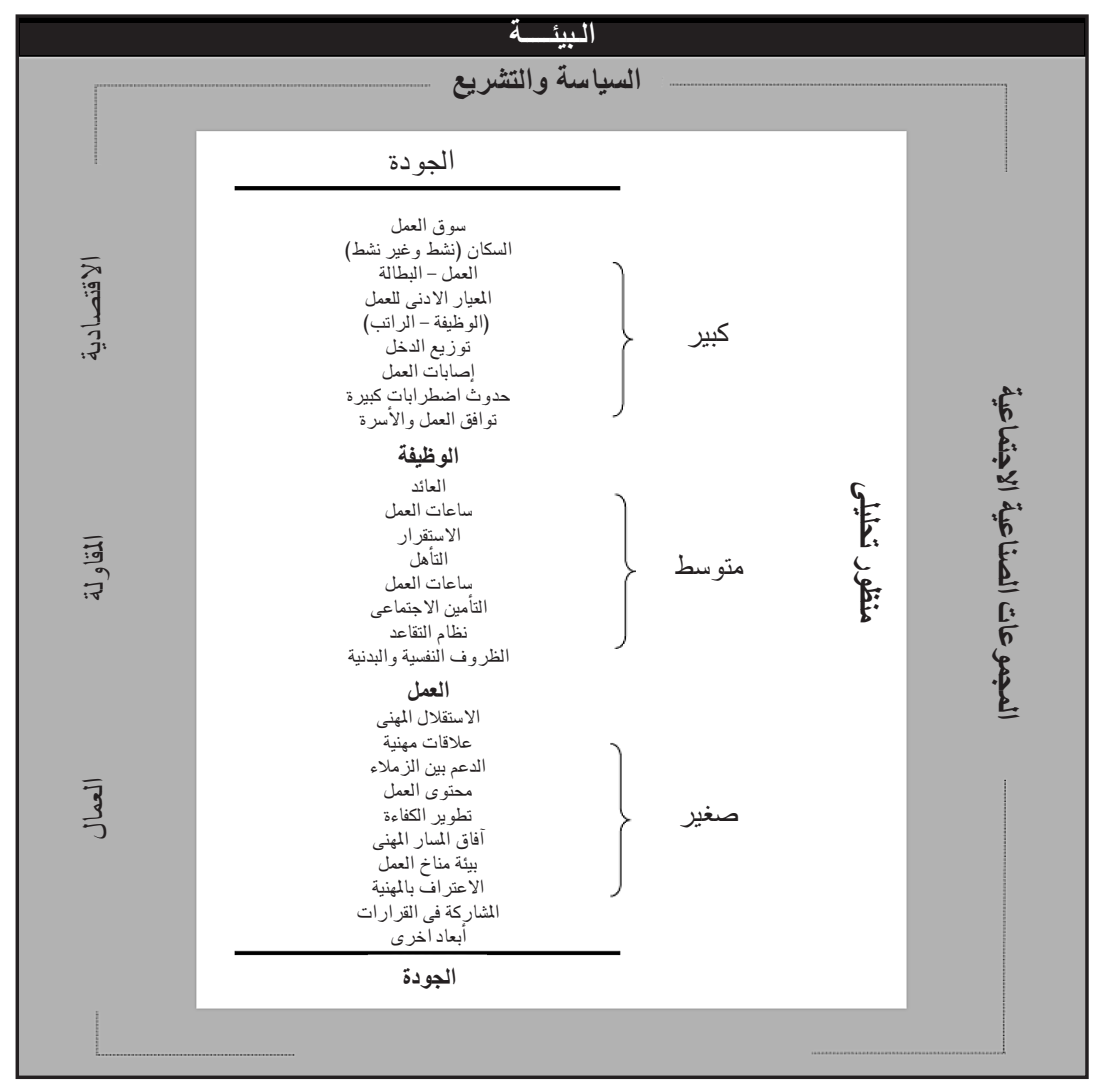

المصدر: معهد الاحصاء بالكيبك (1... ( ).

متوسط (توزانات متعادلة) المؤشرات العشرة المختارة من أحد الجوانب، وبناءً علي التحليل الديناميكي المتوسط للمؤشرات نفسها . ويشير المؤلفون إلي السمة التقريبية للمقاييس المختلفة المقترحة للدخول إلى مبحث جودة العمل . وقد استتجوا نقص البيانات ، وتر اجع المؤشرات الرئيسية، وفي بعض الحالات الأبعاد التي توصي بها المقاربة الأوروبي في مجال جودة العمل.

و من أجل رؤية أشمل لجودة العمل في منطقة الكيبيك (Québec)، قام معهد الإحصاء

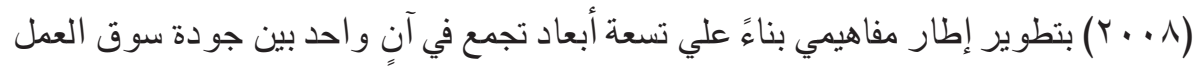
(المستوى الكلي) وجودة العمل (المستوى المتوسط)، وجودة العمل (المستوى الجزئي) • يشير المستوى الأول إلي سياق سوق العمل (أدني حد من السن للعمل، المعايير ، لإنصاف في العمل

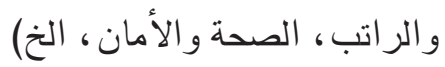




\begin{tabular}{|c|c|c|c|c|c|c|c|c|c|c|c|c|c|c|}
\hline \multicolumn{14}{|c|}{ الأبعاد } & \multirow[t]{2}{*}{ الطلاب } \\
\hline \multicolumn{3}{|c|}{ الإجمائي } & \multicolumn{2}{|c|}{ 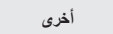 } & \multicolumn{9}{|c|}{ جودة الوظيفة } & \\
\hline الأبعاد & | وادة العقل | & العودة & 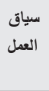 & 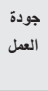 & العطل & التقاعد & الثامل & ساعات & |النظبية & المؤهل & | الاستقرار & ساعات & | المقابل & \\
\hline 20 & 16 & 9 & 4 & 7 & $\Delta$ & 口4 & 口A & 口A & a & a $\Delta$ & 口 4 & 口A & $\mathbf{a \Delta}$ & Lowee 2007 \\
\hline 7 & 3 & 3 & 4 & 0 & & & & & & & - & - & - & СЕTECH ، 2006a \\
\hline 7 & 3 & 3 & 4 & $\mathbf{0}$ & & & & & & & - & - & - & СЕTECH ، 2006b \\
\hline 3 & 3 & 3 & $\mathbf{0}$ & $\mathbf{0}$ & & & & & & & - & - & - & Tabi ، Langlois ، 2003 \\
\hline 24 & 19 & 6 & 5 & 13 & $\boldsymbol{\Delta \Delta}$ & $\square \Delta$ & $\mathbf{\Delta \Delta}$ & 口 A & & & 口 1 & & $\mathbf{a \Delta}$ & $\begin{array}{l}\text { Hughes، Lowe، } \\
\text { Schellenberg، } 2003\end{array}$ \\
\hline 6 & 6 & 6 & $\mathbf{0}$ & $\mathbf{0}$ & घ & - & - & - & & & & - & - & Drolet ، Morissette، 1998 \\
\hline 9 & 9 & 8 & $\mathbf{0}$ & 1 & $\square$ & - & - & & $\Delta$ & $\boldsymbol{\Delta \Delta}$ & 口 & - & 口 A & Karahn ، 1992 \\
\hline 5 & 5 & 4 & $\mathbf{0}$ & 1 & & & & & घ & 口u & $\boldsymbol{\square \Delta}$ & & - & Green ، 2008 \\
\hline 9 & 9 & 4 & 0 & 5 & & & & & $\Delta$ & & $\Delta$ & $\Delta$ & $\Delta$ & Handel 2005 \\
\hline 14 & 14 & 5 & $\mathbf{0}$ & 9 & & $\Delta$ & $\Delta$ & & & & $\Delta$ & $\Delta$ & $\Delta$ & Rose ، 2005 \\
\hline 6 & 6 & 5 & $\mathbf{0}$ & 1 & & - & - & & & & - & - & - & $\begin{array}{c}\text { McGoverm ، Smeaton ، } \\
\text { Hill ، } 2004\end{array}$ \\
\hline 5 & 5 & 5 & $\mathbf{0}$ & 0 & & - & - & & & & - & - & - & $\begin{array}{c}\text { Kaliberg، Reskin ، } \\
\text { Hudson ، } 2000\end{array}$ \\
\hline 6 & 5 & 5 & 1 & $\mathbf{0}$ & & - & - & & & & - & - & - & Meisenheimer II ، 1998 \\
\hline 10 & 6 & 6 & 4 & 0 & & & & - & - & - & - & - & - & CEE ، 2006 \\
\hline 4 & 4 & 4 & $\mathbf{0}$ & $\mathbf{0}$ & & & & - & & & - & - & - & Lemiere ، March ، 2006 \\
\hline 14 & 6 & 5 & 8 & 1 & & & & - & & - & - & - & - & $\begin{array}{c}\text { Commission of European } \\
\text { communities } 2001\end{array}$ \\
\hline 8 & 8 & 5 & $\mathbf{0}$ & 3 & & & & $\Delta$ & $\Delta$ & & 口 4 & E $\Delta$ & $\mathbf{D A}$ & European commission 2001 \\
\hline 2 & 2 & 2 & $\mathbf{0}$ & $\mathbf{0}$ & & & & & & & $\boldsymbol{\Delta \Delta}$ & & $\mathbf{E} \mathbf{A}$ & European commission 2002 \\
\hline 11 & 6 & 6 & 5 & $\mathbf{0}$ & & & & - & - & ! & - & - & - & European foundation 2002 \\
\hline 6 & 6 & 5 & $\mathbf{0}$ & 1 & & & & - & - & & - & - & - & OCDE، 2001 \\
\hline 6 & 6 & 4 & $\mathbf{0}$ & 2 & & & & & $\Delta$ & & $\Delta$ & $\Delta$ & $\Delta$ & OCDE (Clark) ، 1998 \\
\hline 29 & 4 & 4 & 25 & $\mathbf{0}$ & & & & घ & & & - & - & - & OIT ، 2003 \\
\hline
\end{tabular}

ه تقييم موضوعي لجودة العمل

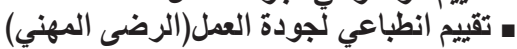
المصدر: معهز الاحصاء بالكييك (ب... (ץ).

يشير المستوى الثاني إلي ظروف العمل ، ويشير بشكل خاص إلي حالة المرتبات ، المؤهل ،

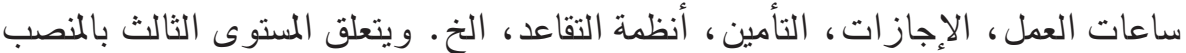
او الفرد في حد ذاته والتي تشير إلي الأسئلة الجوهرية المتعلقة بالعمل، مثل الاستقلالية المهنية، العلاقات المهنية، مضمون العمل، تطور المهارات، المساهمة في اتخاذ القرارات . . . الخ . وقد تم تلخيص هذه المستويات الثلاث في الرسم البياني الموضح. 


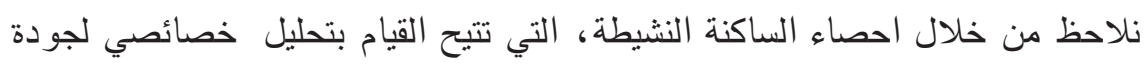

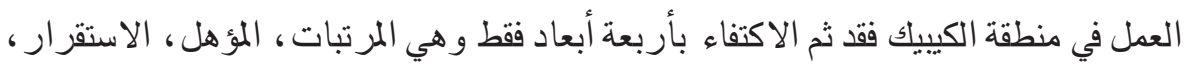

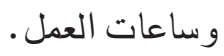

وقد تم مقارنة هذا الإطار ألمفاهيمي عن طريق معهد الإحصاء في كيبيك مع اثنين و عشرين

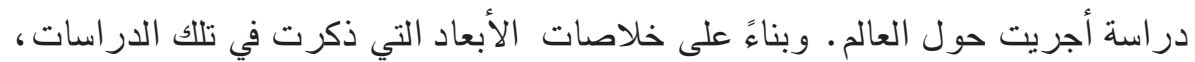

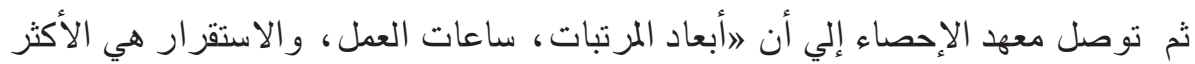

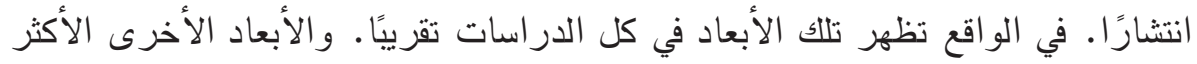

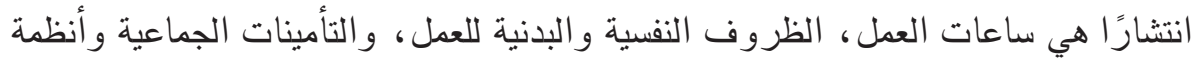

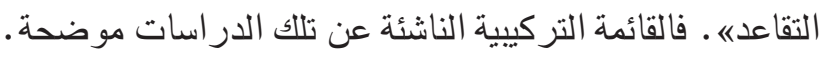

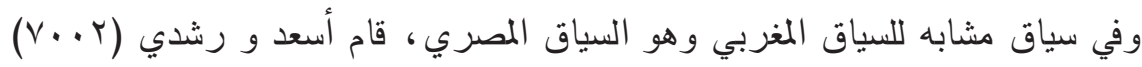

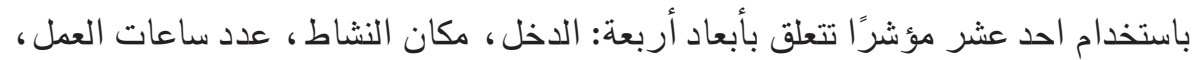

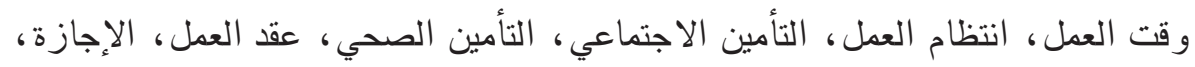

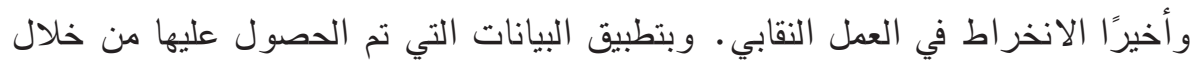

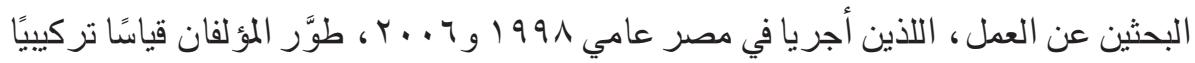

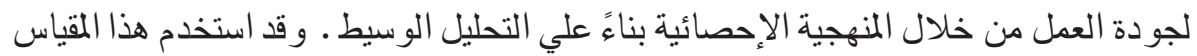

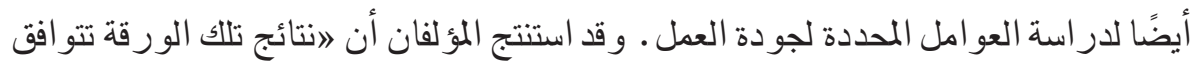

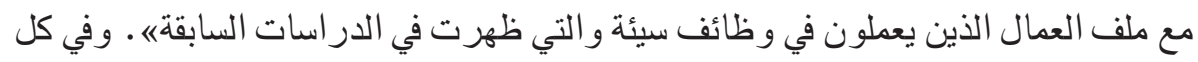

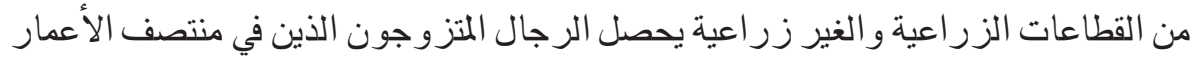

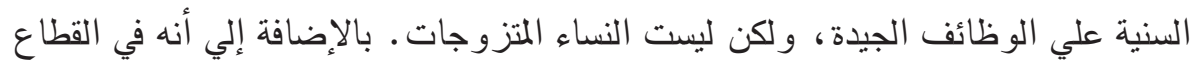

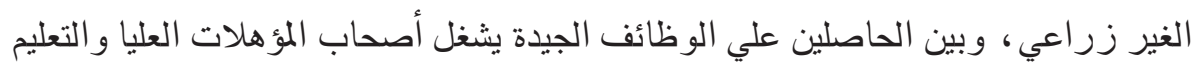
الجيد علي الوظائف الفنية/الاحتر افية، مناصب أصحاب العمل و أعضاء النقابات المهنية.

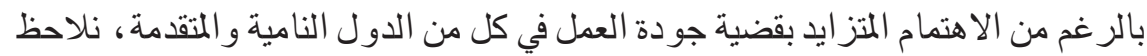

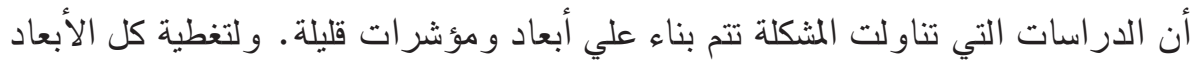
التي أوصت بها منظمة العمل الدولية فقد دعت المنظمة إلي استخدام مصادر إحصائية المئية متعددة.

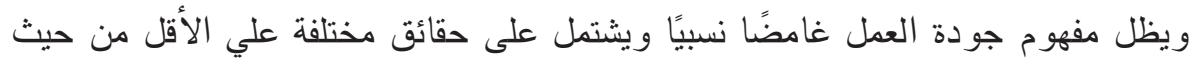

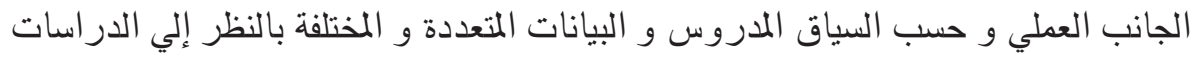
و البيانات المتاحة. 


\section{ب- قياس جودة العمل}

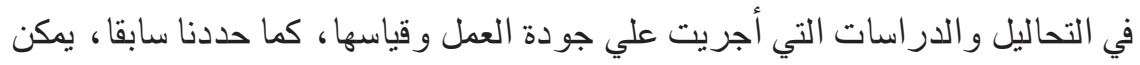

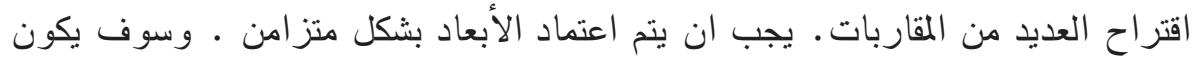

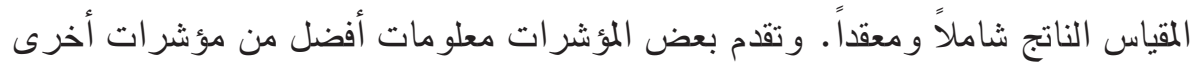

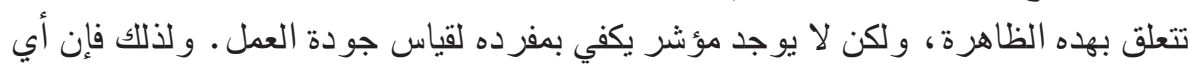

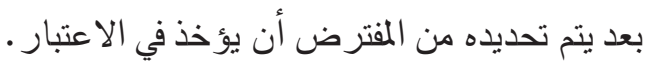

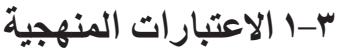

يمكن تطوير العديد من الحجج العملية والنظرية لتبر ير اللجوء إلى مقاربات متعددة الأبعاد

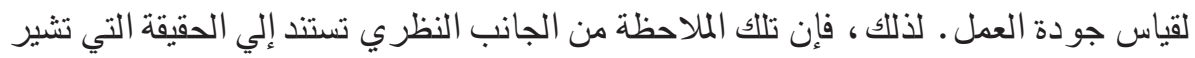

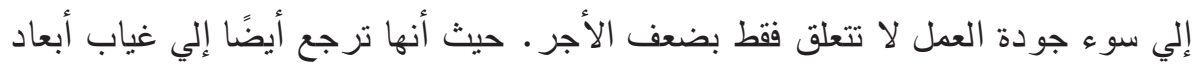

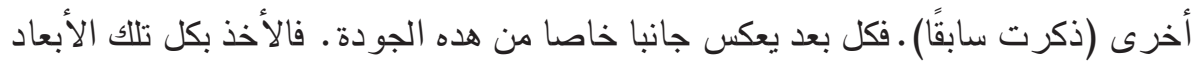

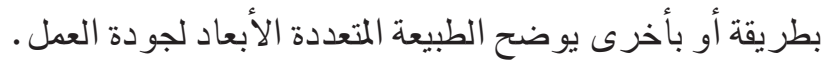

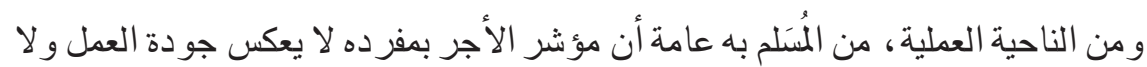

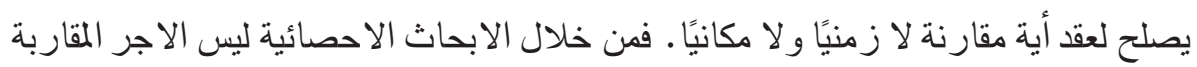
او الزاوية المناسبة المناسبة.

إن مقاربة جو دة العمل لا يمكن لها إلا أن تكون متعدد الأبعاد، أو بمعني أوسع وأشمل

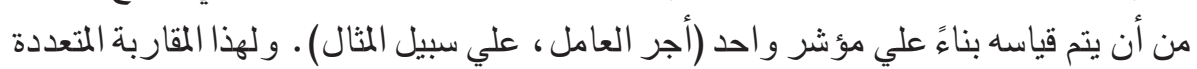

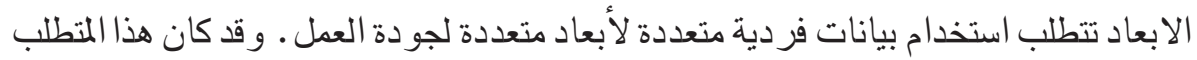

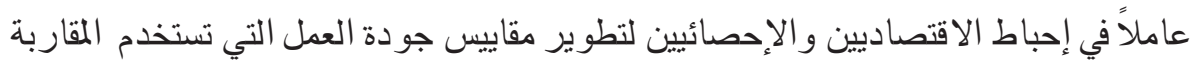
المتعدد الأبعاد في قياس هده الظاهرة.

بالإضافة إلي مثكلة البيانات نظريًا وعمليًا، يبدو من بين المثناكل الجوهرية لاتجاهات

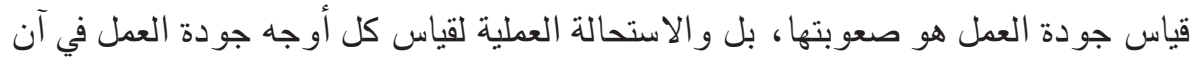

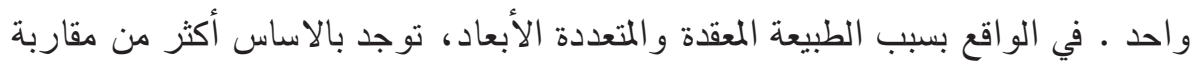

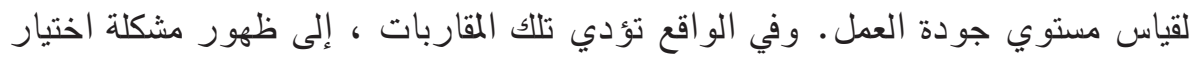

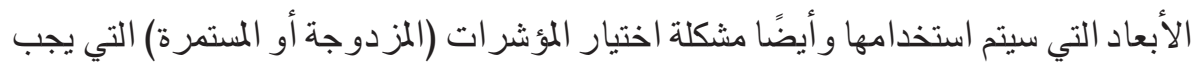

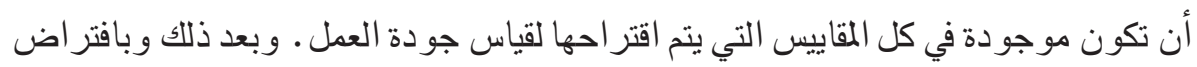


أن مشكلة الأبعاد التي سوف يتم استخدامها قد تم حلها، تظهر مشكلة أخرى تتعلق بتجميع (أو

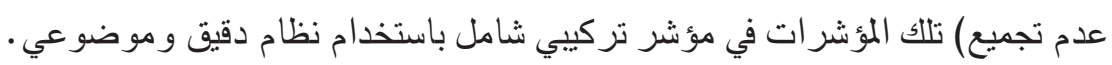

ودائما في اطار مسار تطوير مقياس متعدد الأبعاد لجودة العمل، تظهز مشكلة تطوير

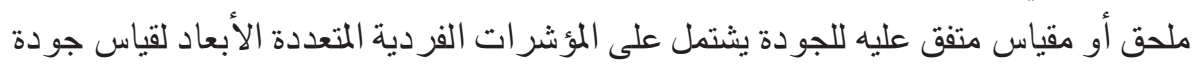

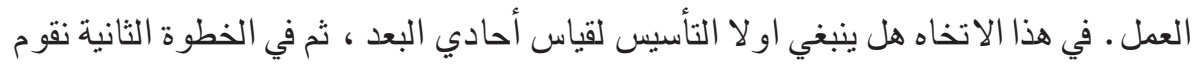

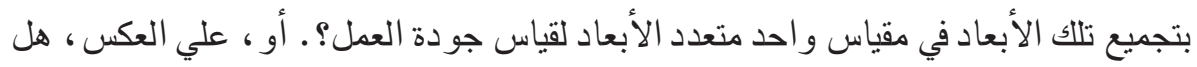

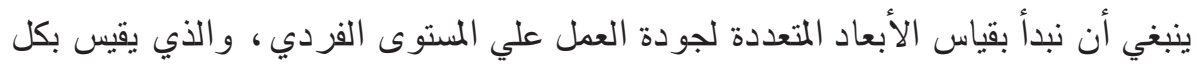

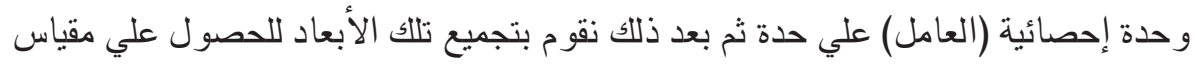

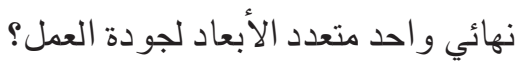

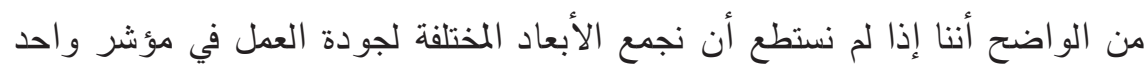

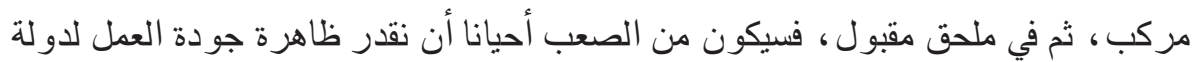
ما أو لمنطقة جغر افية.

وبعد التغلب علي بعض المثاكل العملية و النظرية المتعلقة بالمقاربة المتعددة الأبعاد لظاهرة

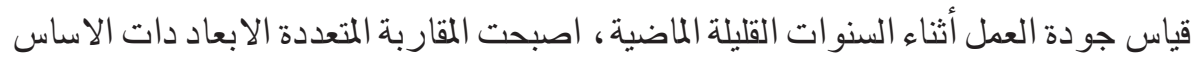

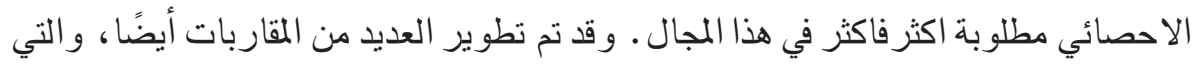

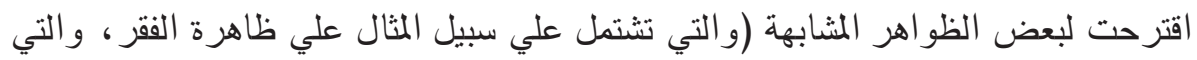

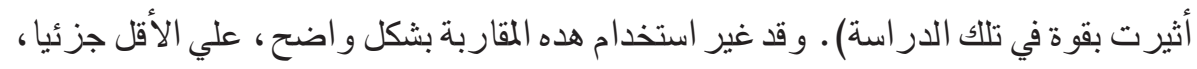

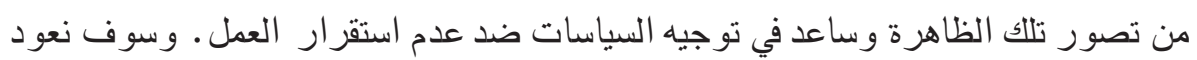
إلي أحد تلك المقاربات: وهي المقاربة الوسيط التي تستند إلى تحليل التطبيقات المتعددة .

\section{r-Y هدف المبحث الوسيط في مبحث جودة العمل}

نهدف هنا إلي القيام بنقلة نظرية نحو إيجاد مقاربة متعدد الأبعاد لقياس هده الظاهرة

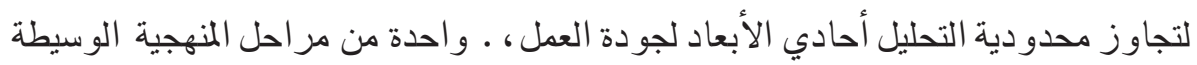

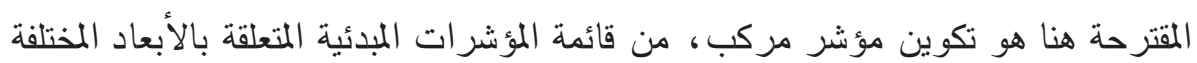
لجودة وظيفة الأفر اد (النشيطين العاملين) .

من المفترض أن يلخص هذا المؤشر حالة الوحدات الإحصائية بالنظر الى المناصب التي

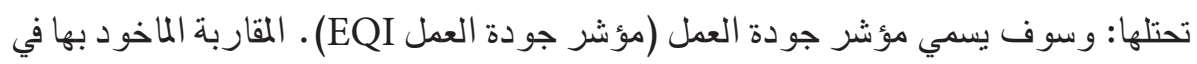


هذه الدراسة تتاسس على المنهجية الإحصائية المتعددة (الوسيطة) . تتجسد في جعل البيانات

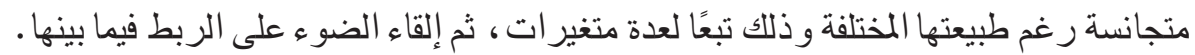
و تحليل التطابقات المتعددة (MCA) الموجود في الدر اسات المتز امنة للمتغير ات اتلمات المتعددة المتعلقة

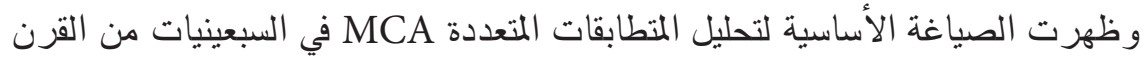

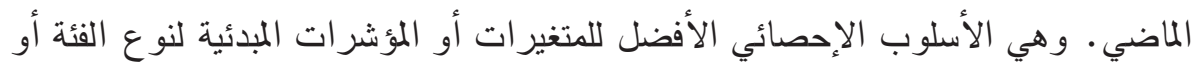

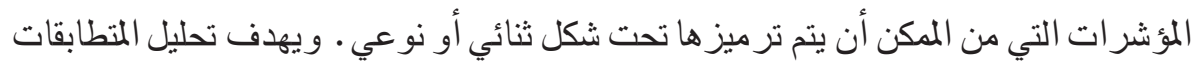

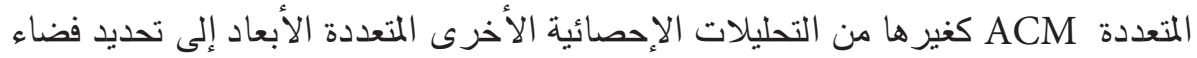

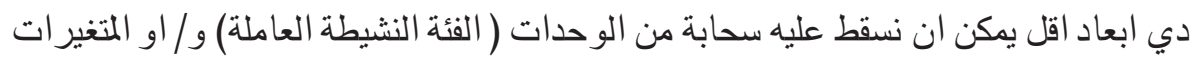

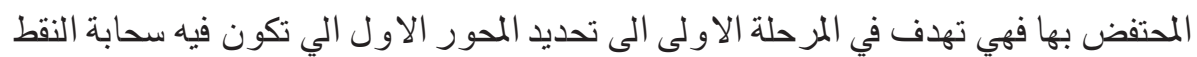

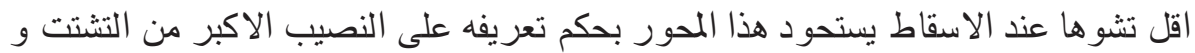

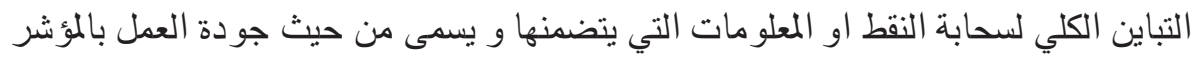

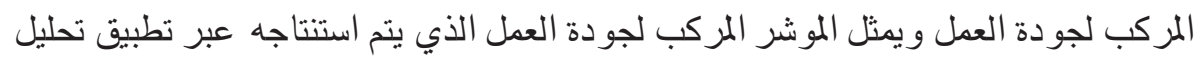

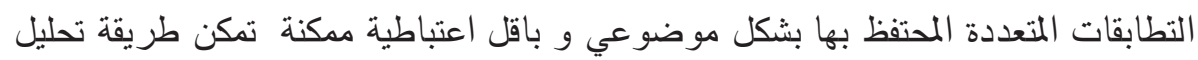

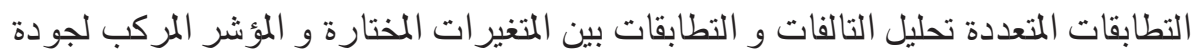
العمل.

و مؤشر جودة العمل الذي يطرحه تحليل التطابقات المتعددة ACM هو ترابط خطي

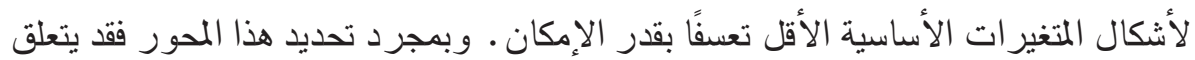

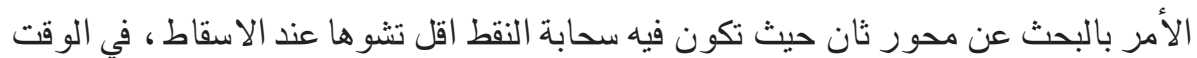

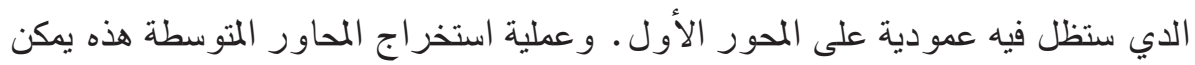

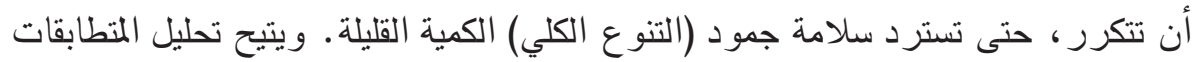

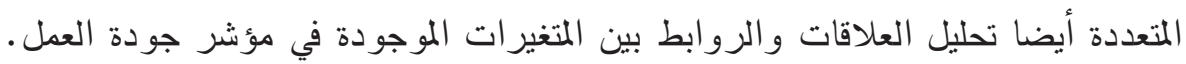

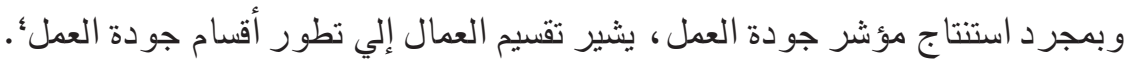

\section{r-r مساهمة التصنيف التسلسلي التصاعدي}

لاستنتاج العينات المتجانسة من العمال طبقًا لجودة العمل، في هده الدراسة، تم استخدام

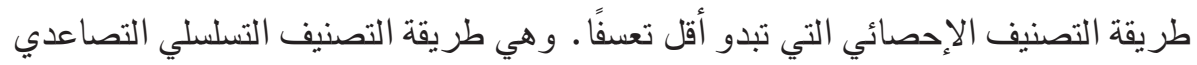
|الاطار في الملدق رقم (() يعطي تثكيل حسابي ومفصل عن MCA التي تم استخدامها 
(CAH) . وتهدف طريقة التصنيف التسلسلي التصاعدي CAH إلي التأسيس بشكل منسجم

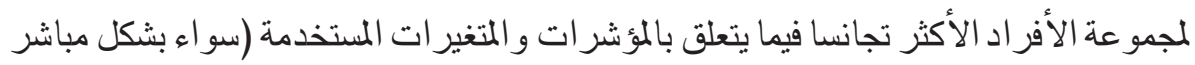
أو من خلال المتوسط الذي تم استتاجه من تحليل المتطابقات المتعددة).

و الـCAH هو طريقة تصنيف تهدف إلي تطوير طبقات الأفراد بشكل متسق. و وتلك المكان

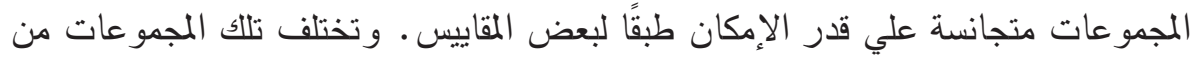

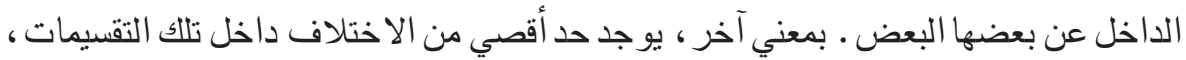

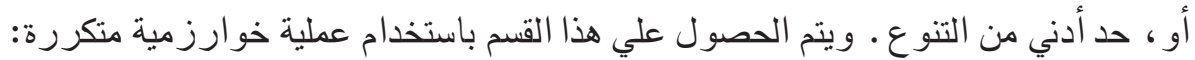

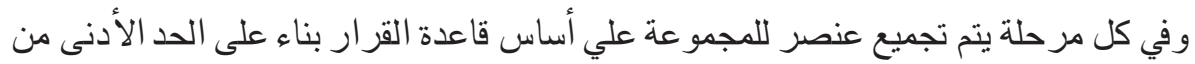

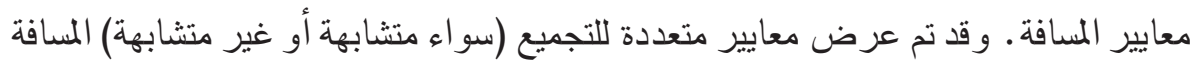

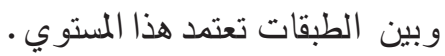

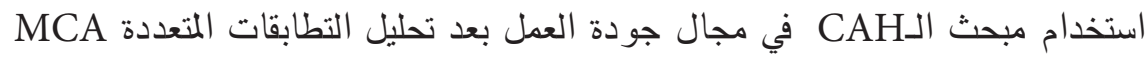
لانثاء طبقات متجانسة ـ و المتغير ات المستخدمة من الممكن أن تكون من بين المتغير ات الأساسية

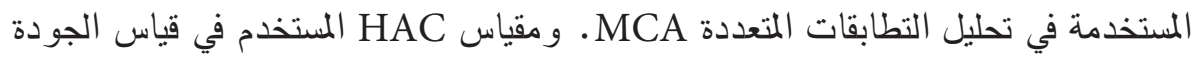
هو العلاقة بين الجمود القائم بين الطبقات عن طريق الجمود الكلي للكمية القليلة للأفراد.

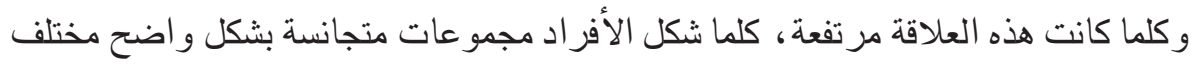

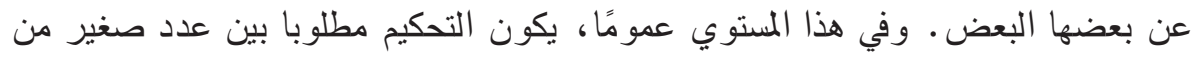

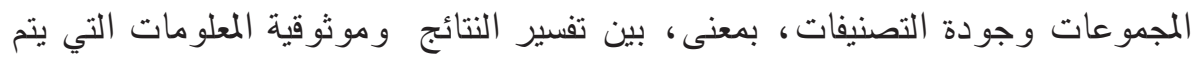

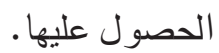

يئدي الـCAH إلي إنشاء شجرة تسلسلية، وهو التصنيف الذي يوضح تقسيم السكان إلي

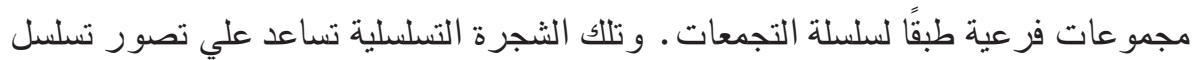

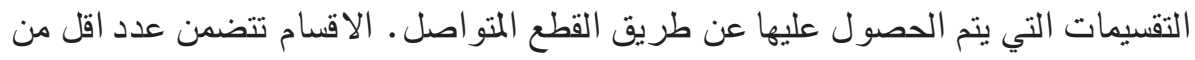

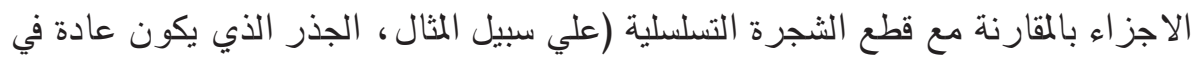

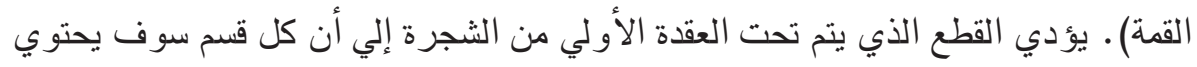

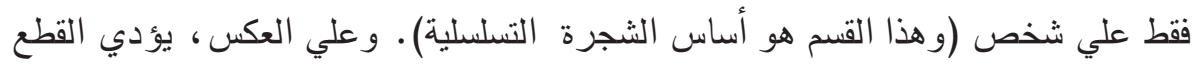
الذي يحدث خلف الجذع إلي قسم واحد يحتوي علي كل الأفر اد.

دائما ما تكون الـCAH ضرورية لمتابعة المراحل المختلفة. الخطوة الأولي هي اختيار

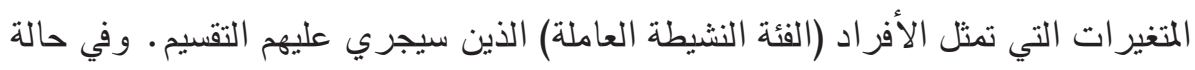


ما إذا كانت البيانات الملحوظة هي قيمة مجموعة المتغير ات الرقية للأفراد، يمكن أن نختار

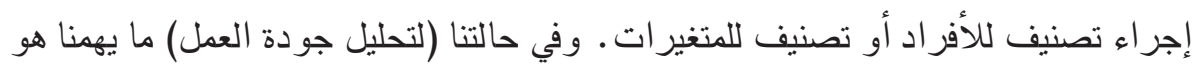

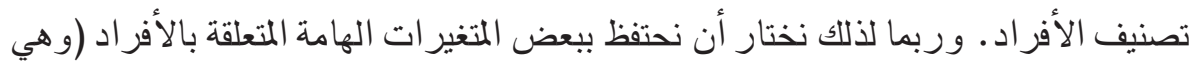

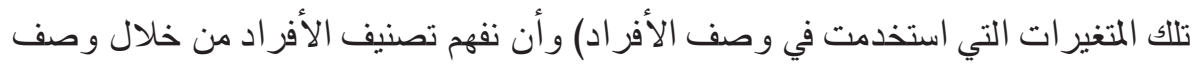
تلك المتغير ات.

و على المستوى الإحصائي الأمر ذاته ينبغي لانجاز تحقيق الـHAC للأفر اد عبر متغيرات

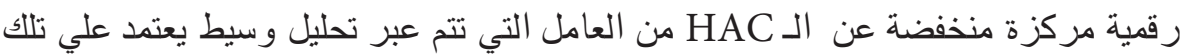
المتغير ات ذاته.

\section{ع- مصادر البيانات وخصائص سوق الشغل في المغرب}

\section{צ-1 بحث سوق الشغل في المغرب:}

المصدر الاساسي لبيانات بطريقة اقتصادية جزئية لسوق الثغل هو البحث الوطني للثغل .

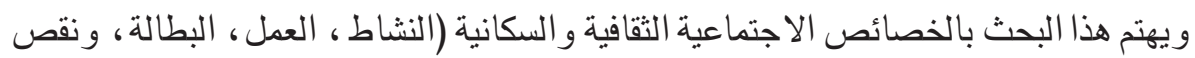

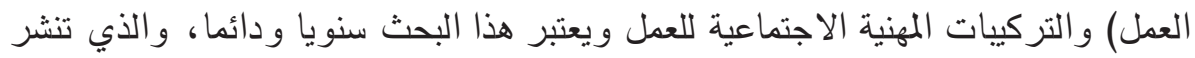
نتائجه وطنيا حسب مجال الإقامة و المناطق الاقتصادية.

و تتو افق المفاهيم و التعر يفات الأساسية المستخدمة مع توصيات منظمة العمل الدولية BIT.

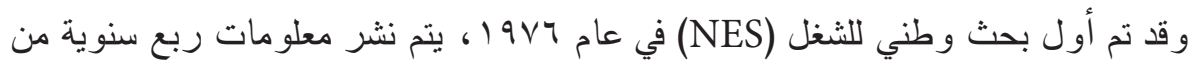

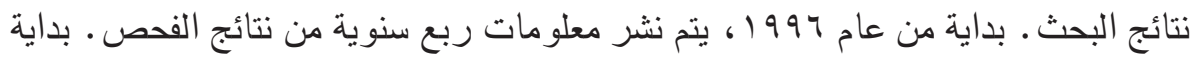

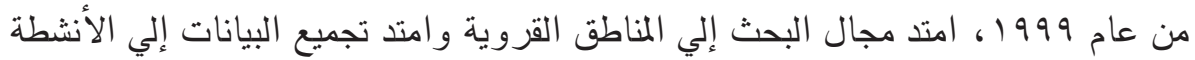

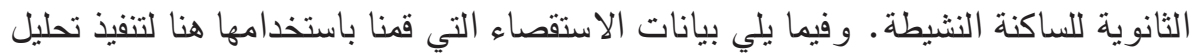

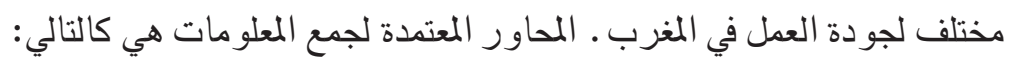

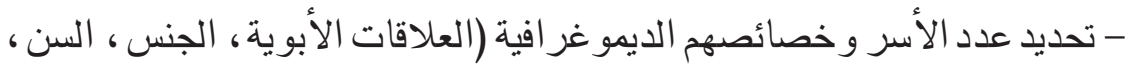
الحالة الاجتماعية ومحل الميلاد)المستوى الثقافي (مستوى التعليم ، الثو اهد، الامية) - نوع النشاط للأشخاص من V سنوات فما فوق - خصائص الساكنة النشيطة العاطلة: نوع البطالة، مدة وأسباب البطالة، التسجيل في

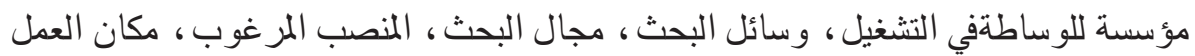




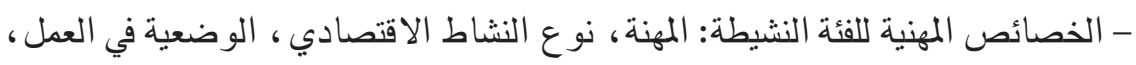

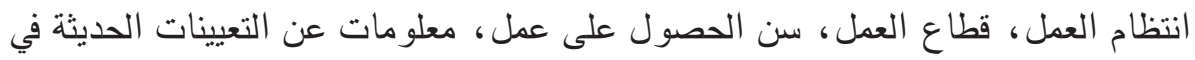

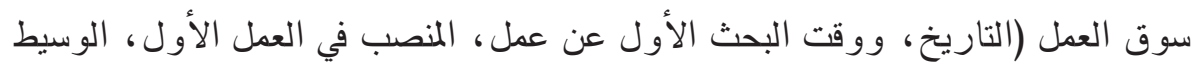

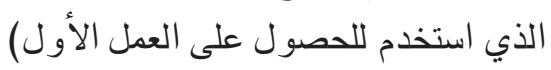

- اعدم تلاؤم العمل مع كفاءة الفئة النشيطة : القضايا التي اقترحت في هذه العينة عبارة

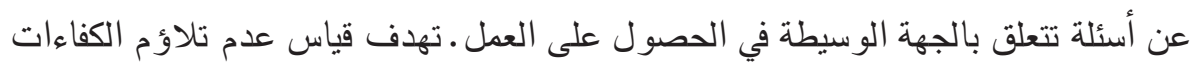

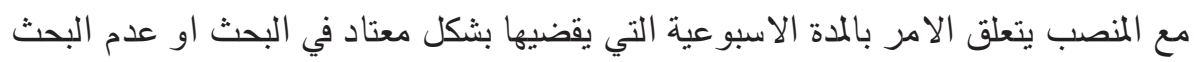

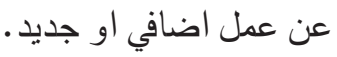

\section{r-r الخصائص الرئيسية لسوق العمل في المغرب:}

ظلت مشكلة الشغل في المغرب تحت تأثير العديد من العوامل منذ ما يزيد علي أربعين

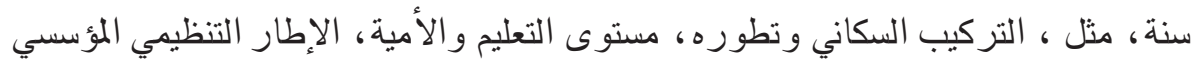

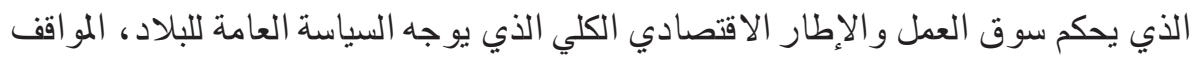

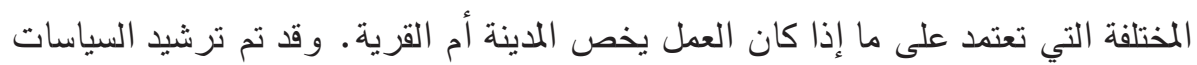

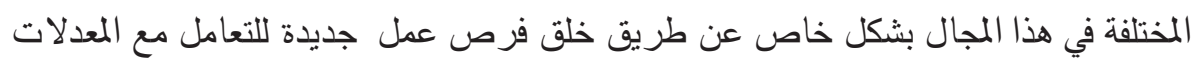

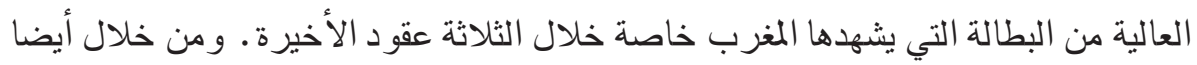

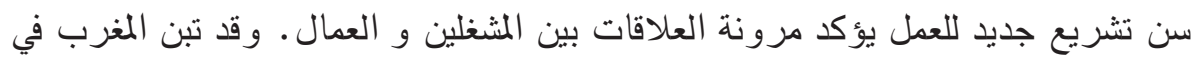

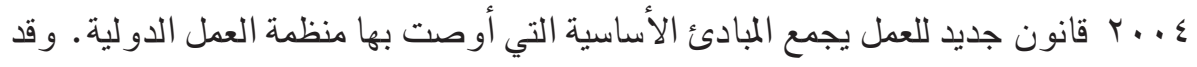

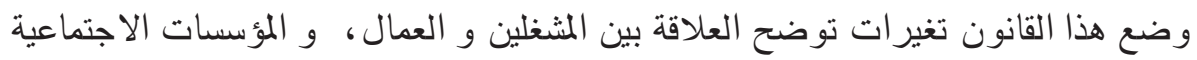

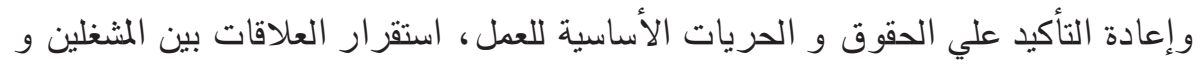

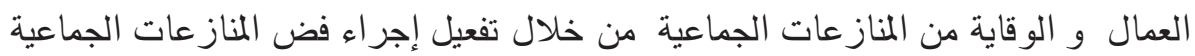

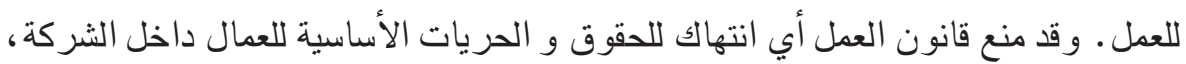

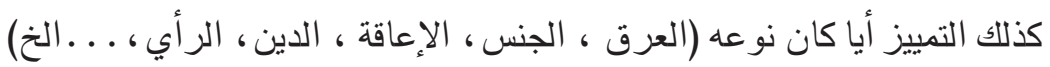

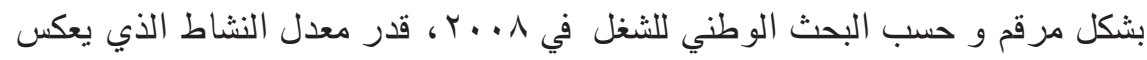

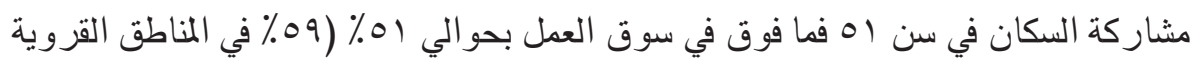

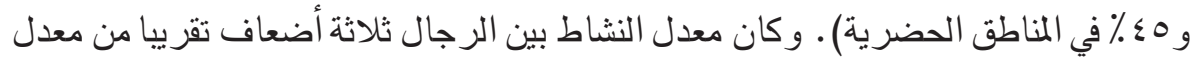

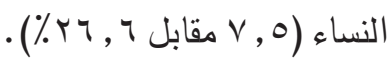

بالإضافة إلي أن الزراعة تشغل نسبة كبيرة من العمال . حيث أن نسبة اء٪ من العمال 


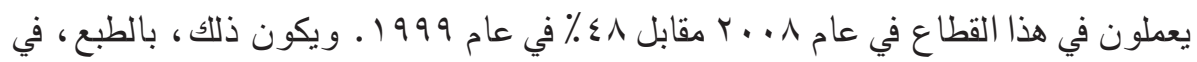

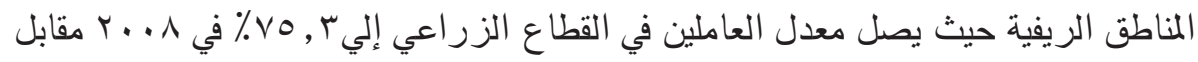

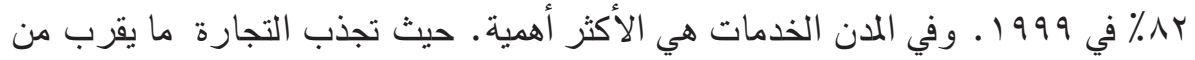

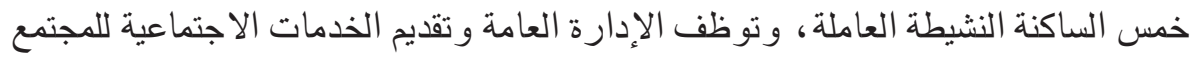

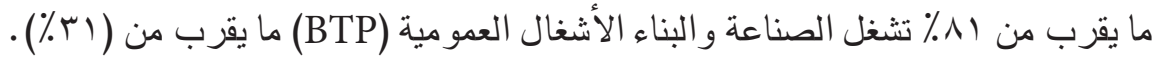

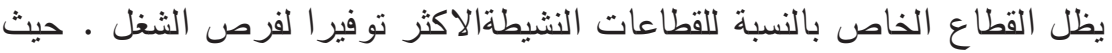

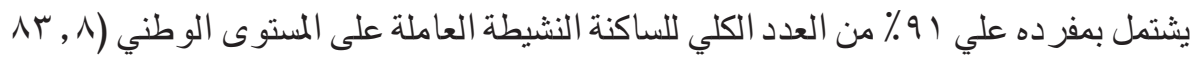

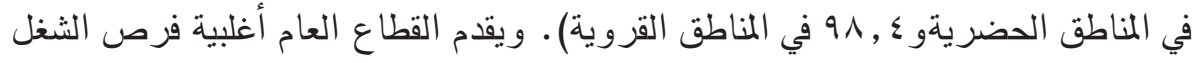

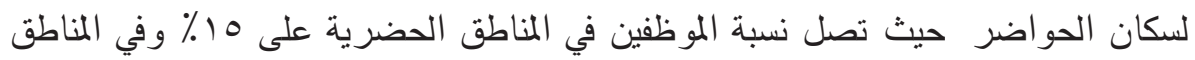

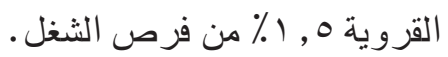

بالإضافة إلي أن النشاط الاقتصادي الغير مدفوعة الاجر و التي تثبه الدعم الأسري

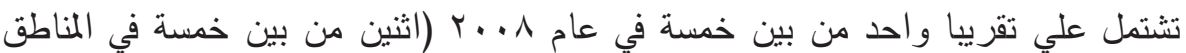

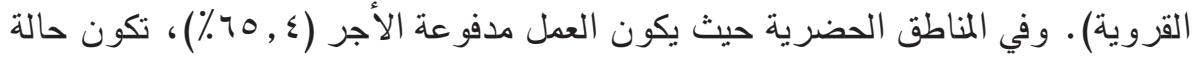

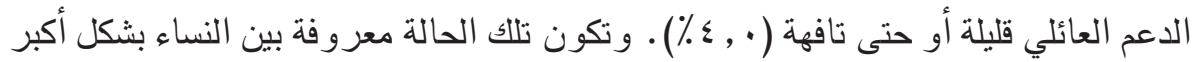

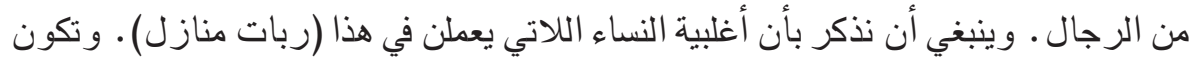

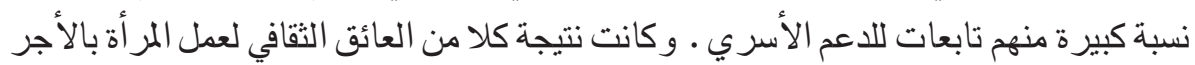

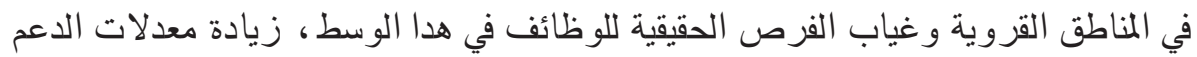

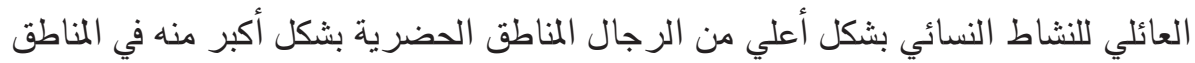

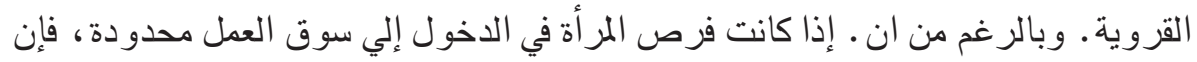

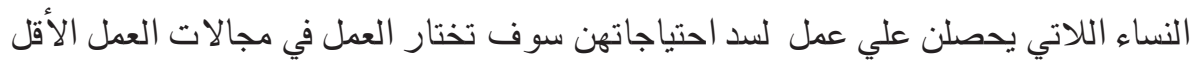

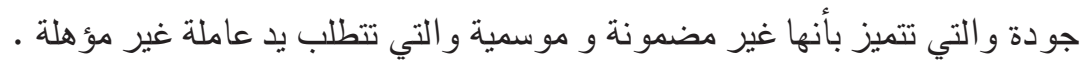
ويجب أن نتذكر أن الحقيقة التي تثير إلي أن النساء يعانين من رأس المال البشري

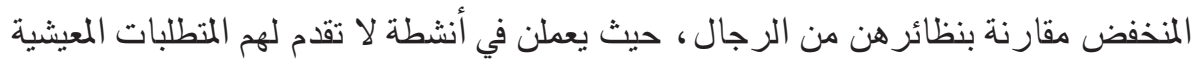

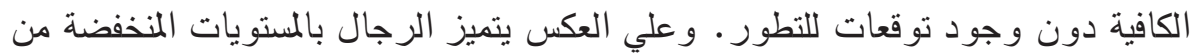

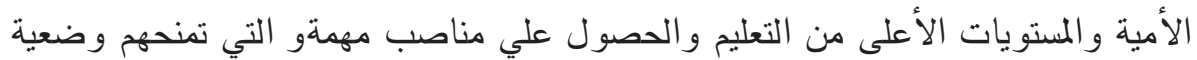

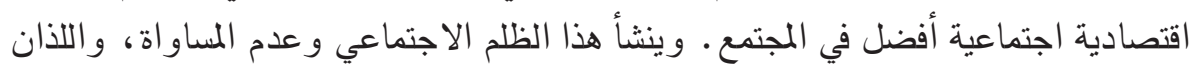

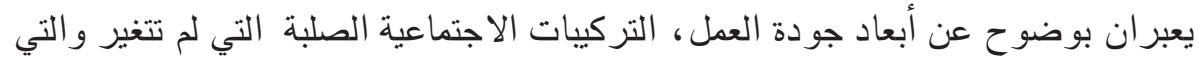

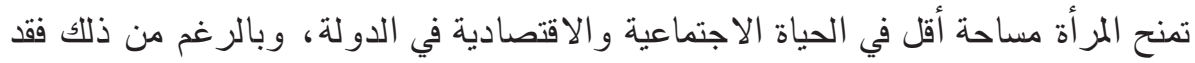
شهدت المغرب تقدما واضحا في مجال تشريع العمل الذي يتعلق بهده المثكلة. 
في الواقع ، صادق المغرب علي العديد من المعاهدات الدولية لتحسين جودة العمل فيما

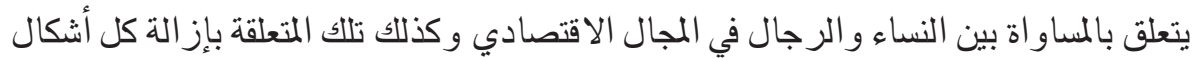

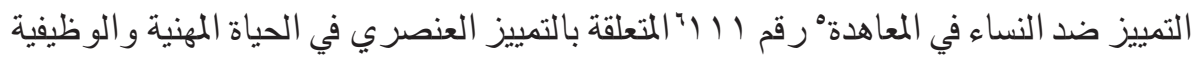

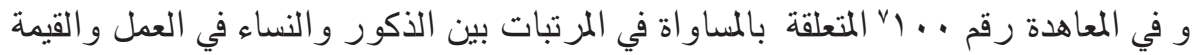

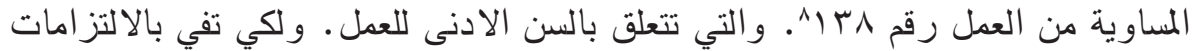

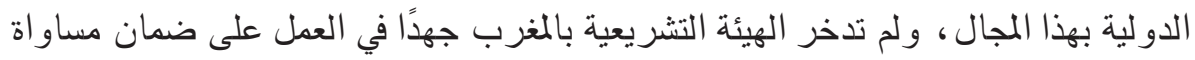

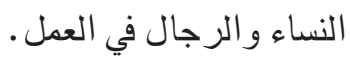

وبنفس الطريقة ، بخصوص تثريعات العمل المطبقة على المأجور ين في الوظائف العمو مية

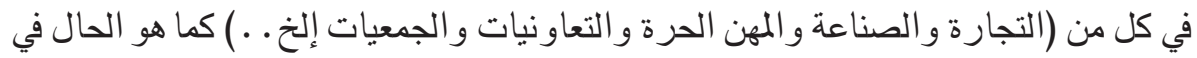

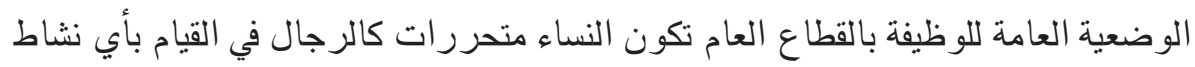

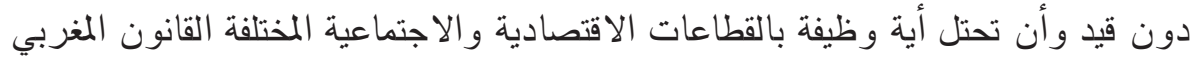

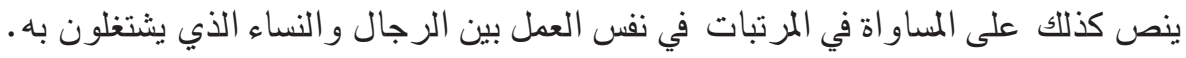

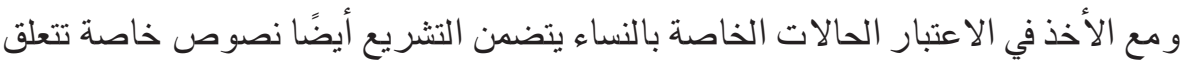

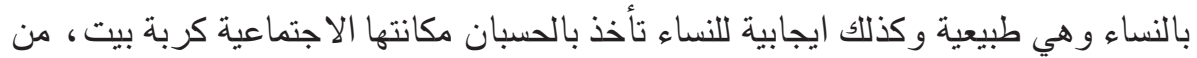

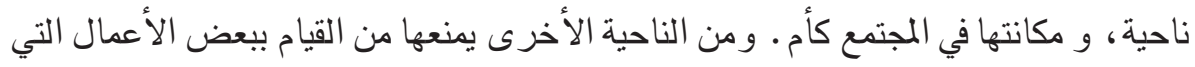

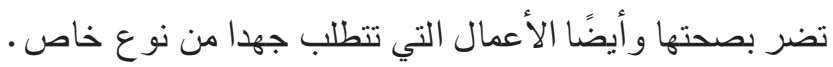

و فيما يتعلق بالسكان العاطلين عن العمل بالمغرب فلقد بلغ أعلى مستوى له في عام 1999

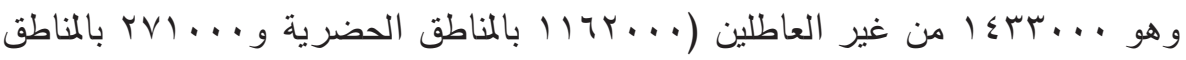

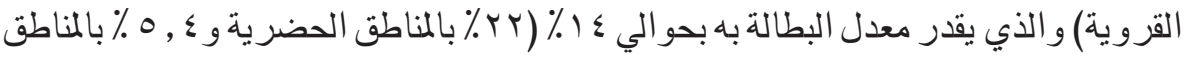

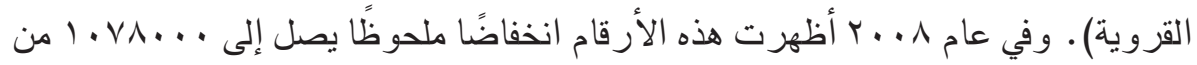

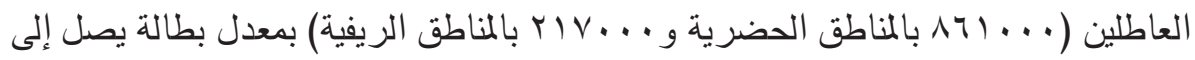

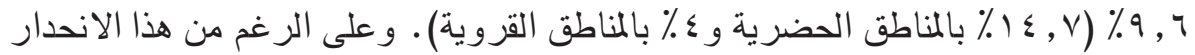

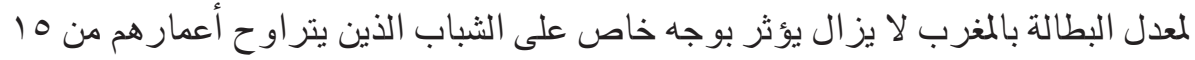

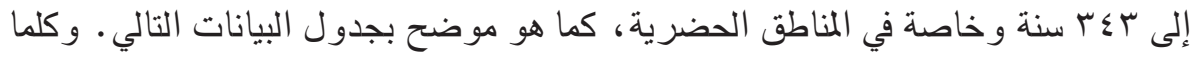

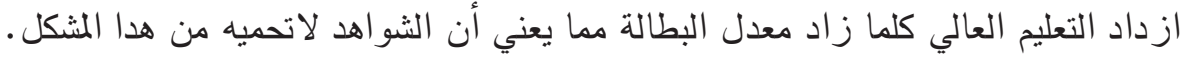

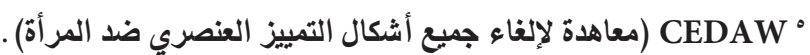

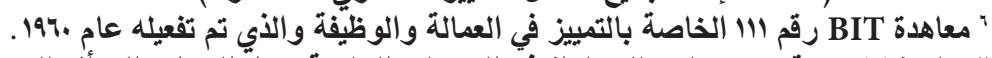

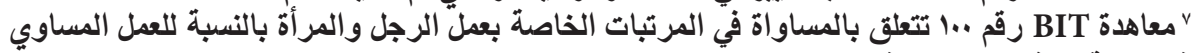

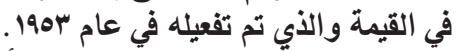

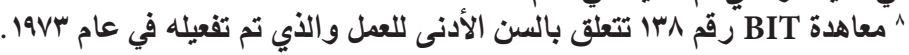




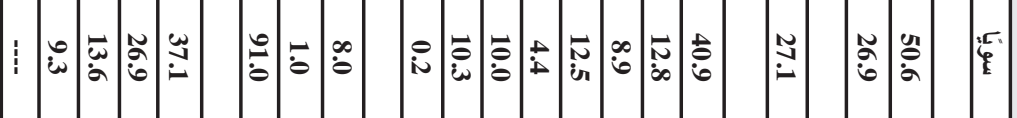

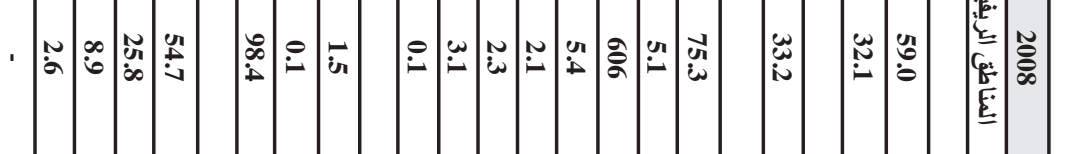

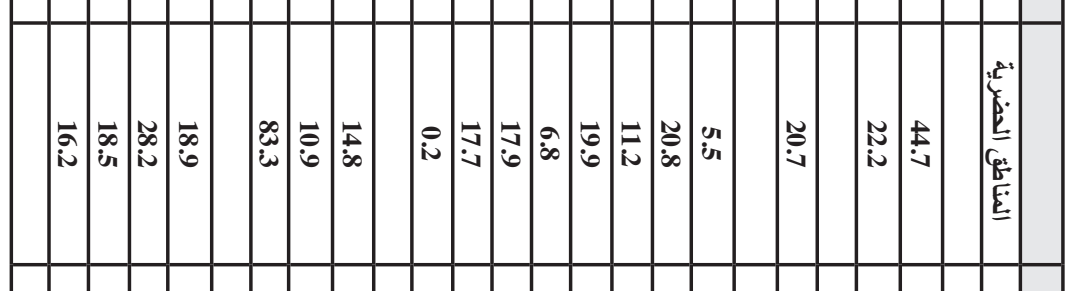

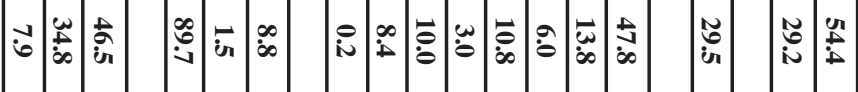

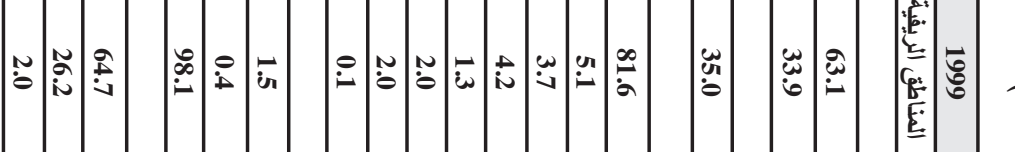

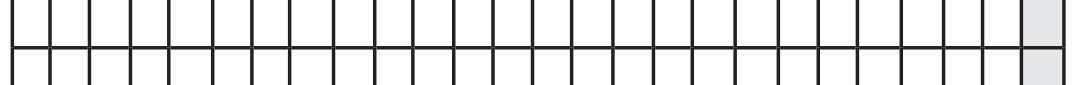

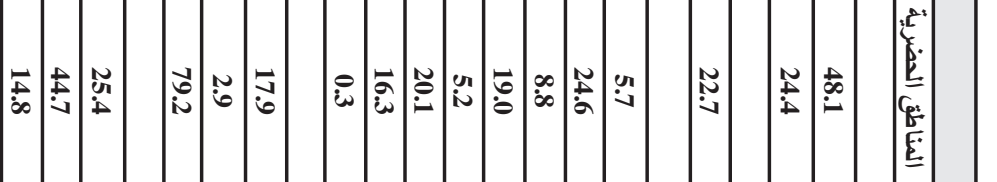

\begin{tabular}{llllllll|l|l|} 
& & & & & & & & & \\
\hline
\end{tabular}

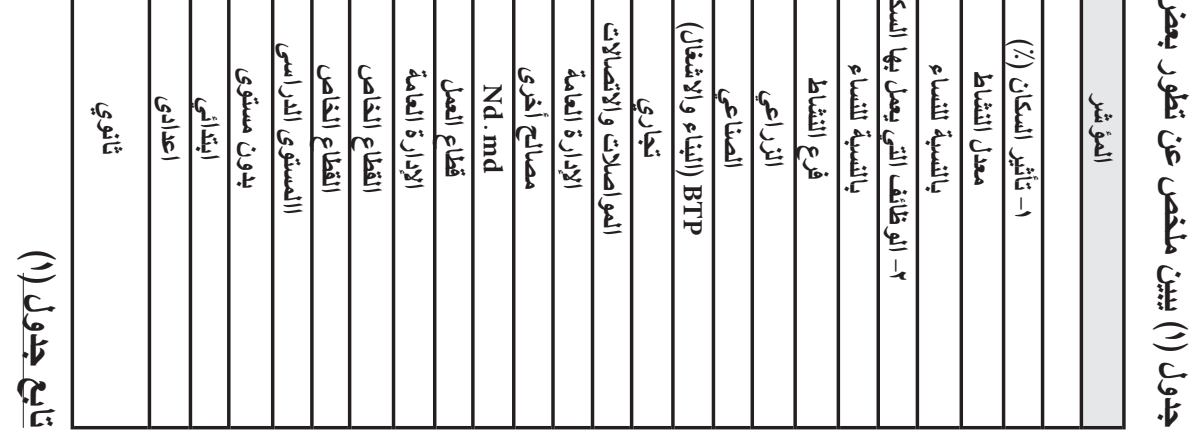

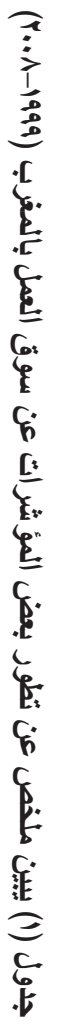




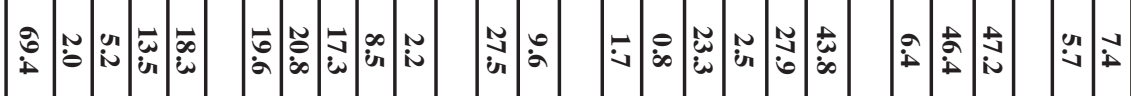

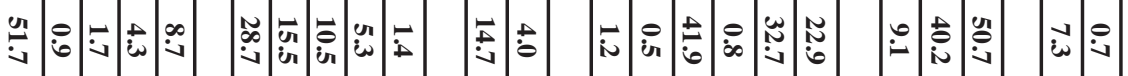

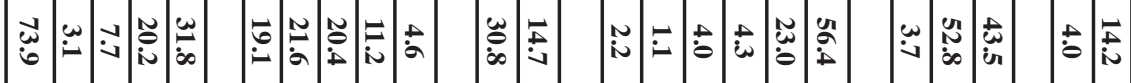

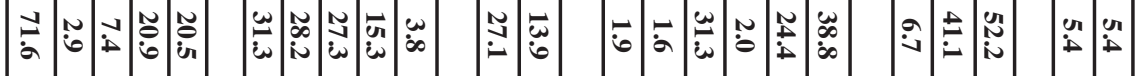

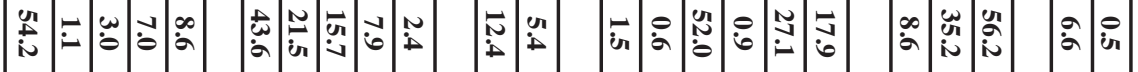

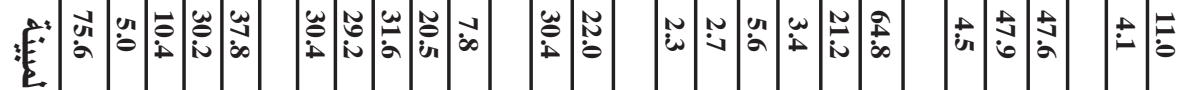

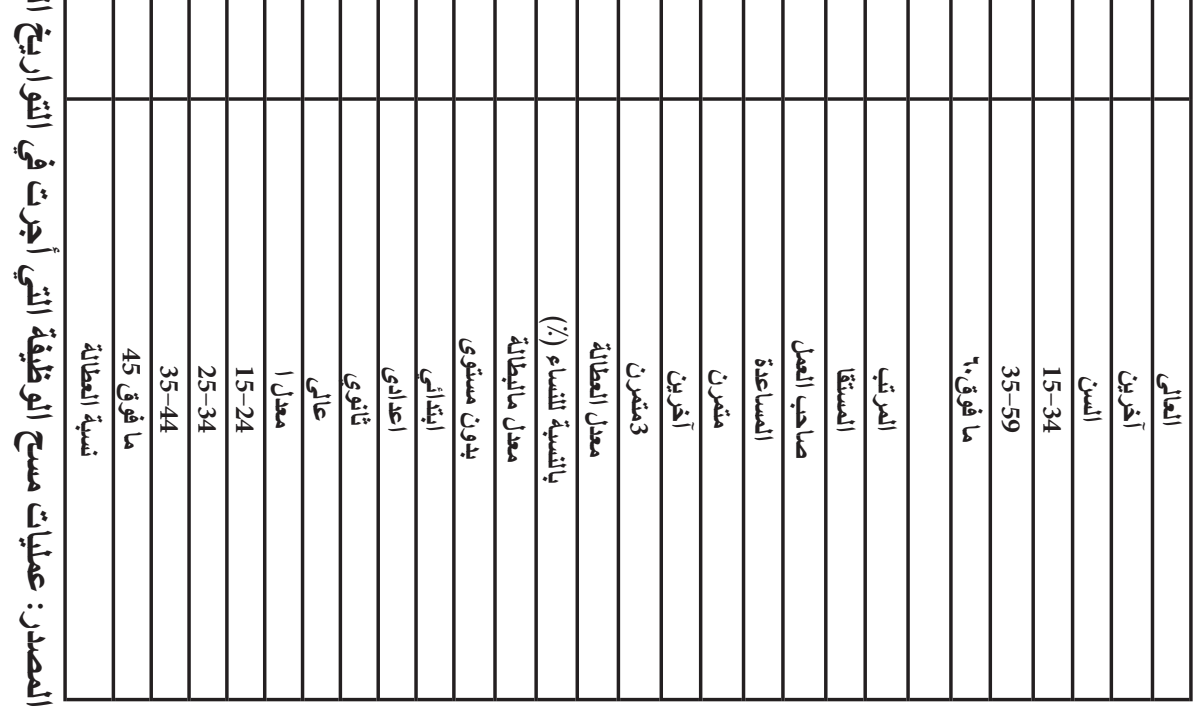




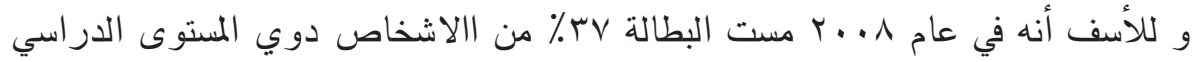

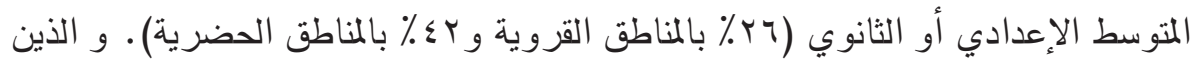

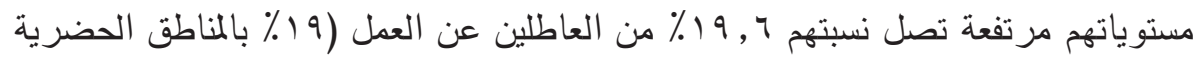

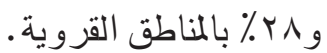

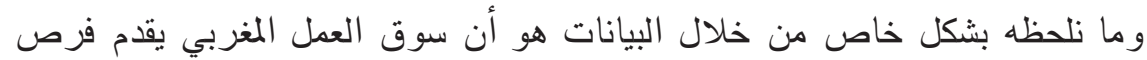

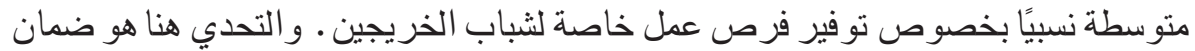

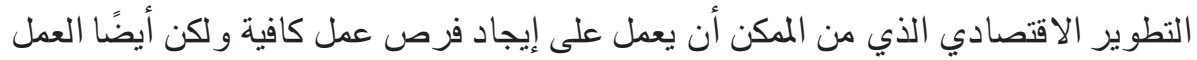

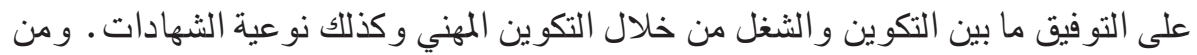

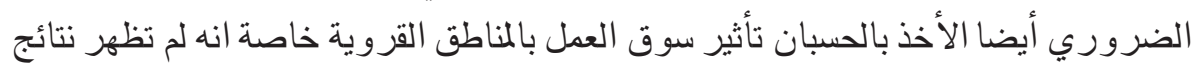

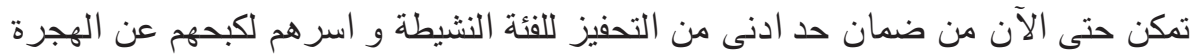

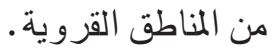

بيد أن هذا الحل مقلق مقارنة بالتغير ات التي طر أت على المجتمع المغربي و التي تشكل

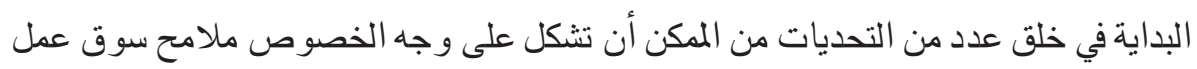

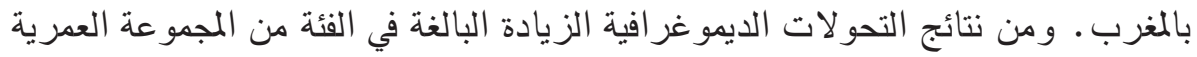

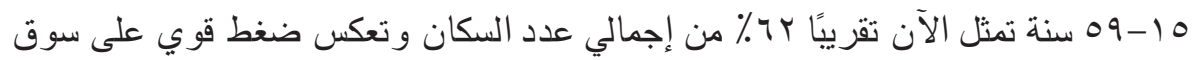

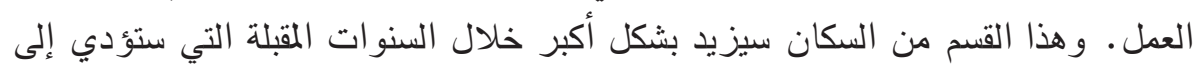
وصول الكثير من الثباب لسوق العمل وهو في وضعية غير متو ازنة.

\section{r-r أبعاد ومتغيرات جودة الوظيفة بالمغرب}

يتيح لنا كل من البحث الوطني للشغل ENE في عام 1999 و وبعض النتائج الموضحة سابقًا

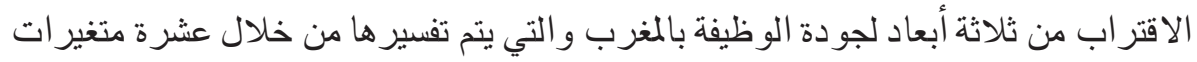

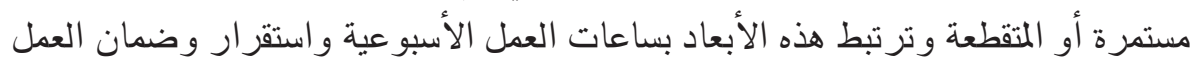
و الضمان الاجتماعي. و تعد أساليب الأجور غير متاحة بلاد بما لدينا من بيانات.

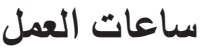

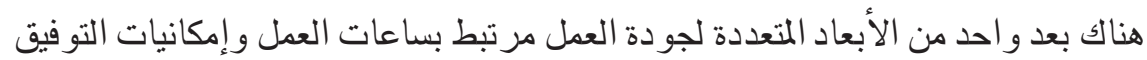

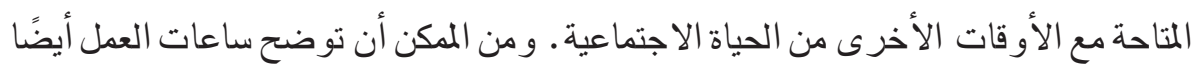

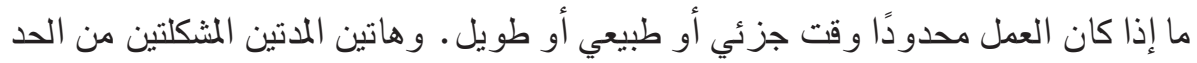




\section{الجدول (ץ) : ملخص المتغيرات المتعلقة باستقرار وضمان العمل .}

\begin{tabular}{|c|c|c|}
\hline \multicolumn{2}{|c|}{ الأسائيب المتبعة } & المتغيرات \\
\hline - عمل دائم غير متفرغ . & - عمالة مؤقتة وموسمية دمائة . عتفة . & دوام العمل \\
\hline - عقد لفترة غير محددة . & |- عدم وجود عقد أو وجود اتفاق شفهي. & عقد للعمل \\
\hline - من 36 شهرا إلى 96 شهر أ شهرا. & - - من - 96 إلى من 36 شهرا. & الاقدمية في العمل \\
\hline - لا يوجد. & 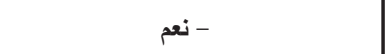 & الرغبة في تغيير العمل \\
\hline - مع ساعات عمل طويلة. & - الحصول على عمل ثانوي لحصة غير & في ت اسباب الرغبة \\
\hline$\gamma-$ & 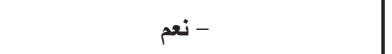 & البحث الفعال عن عمل آخر \\
\hline$\gamma-$ & 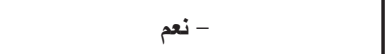 & القيام بأعمال ثانوية \\
\hline مقر السكنة & 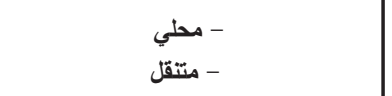 & مكان العمل \\
\hline
\end{tabular}

الادنى و الحد الاقصى هما من خصائص جو دة العمل السيئة وهو أنه بالنسبة لهذين الجانبين

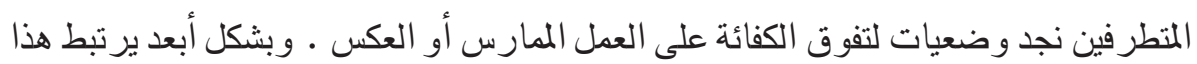

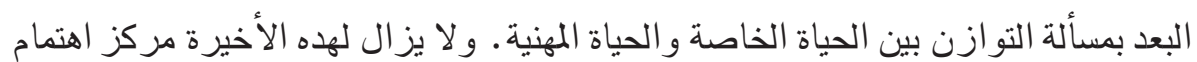

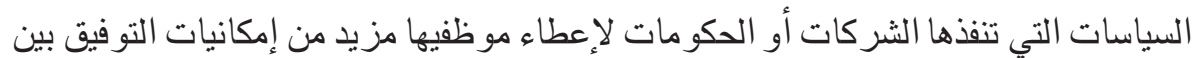
الحياة الأسرية و الحياة المننية.

وسنتاول في دراستنا هذا البعد الذي سيتم مقاربته بمتغير مرتبط بمدة العمل الأسبو عية

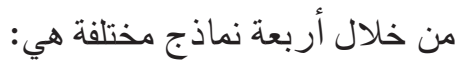

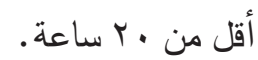
من · ب إلى •ـ ساعة.

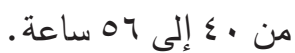

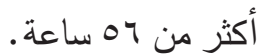

\section{استقرار ضمان العمل:}

احد ابعاد جودة العمل التي يمكن الاحتفاض بها انطلاقا من البيانات المتوفرة بالنسبة 
للمغرب، ذلك البُعد الخاص بالاستقر ار وظروف العمل ـ و هو بُعد يقدم معلو مات حول العمل

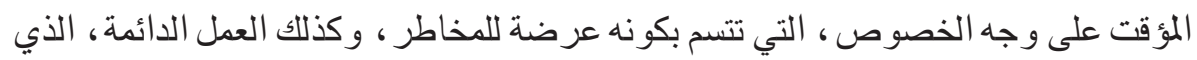

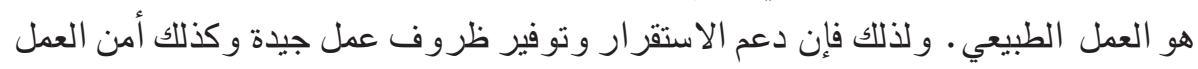

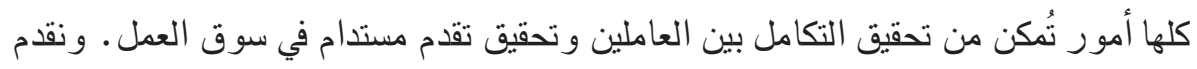

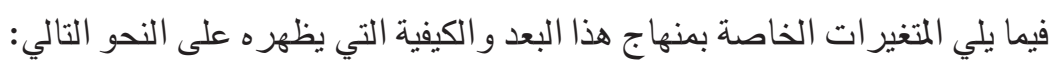

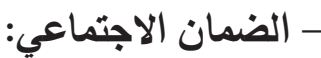

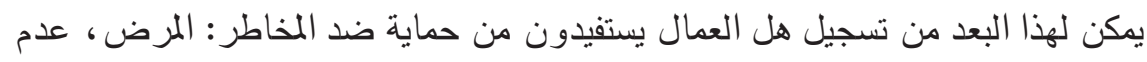

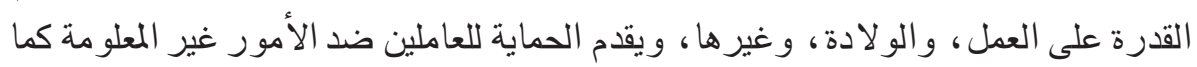

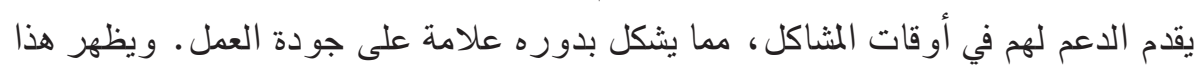

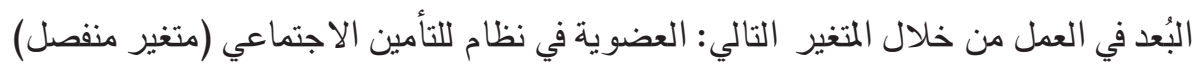

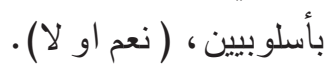

\section{ه- جودة العمل في المغرب: أوضاع مختلفة}

لتطبيق المنهج النظري المثار اليه باستخدام البيانات التي تم الحصول عليها من البحث

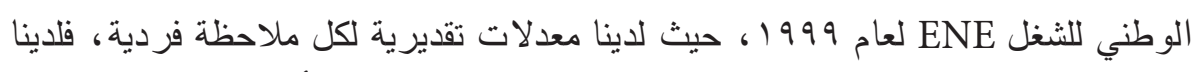

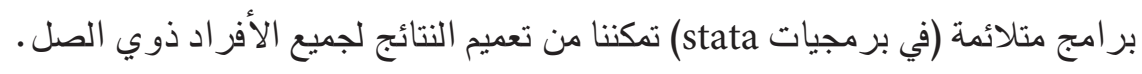

\section{1/1 بعض الخصائص الوصفية لقاعدة البيانات المستخدمة:}

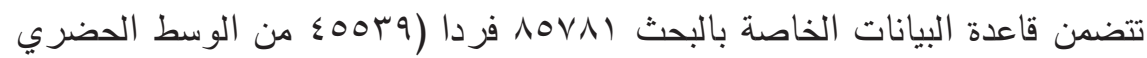

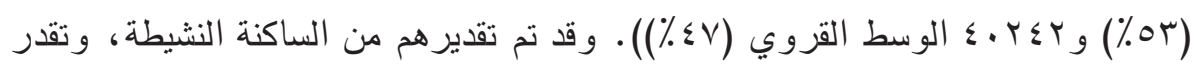

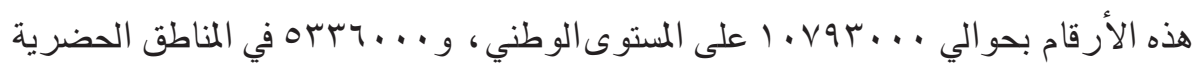

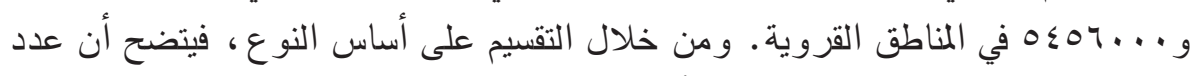

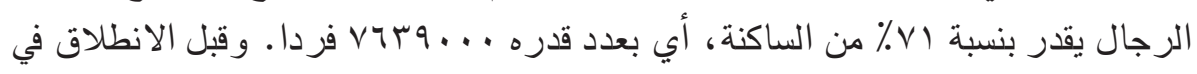

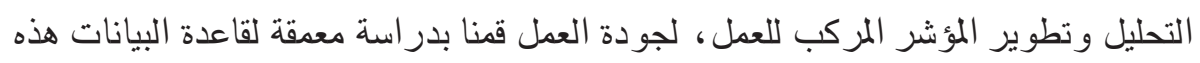
وبيانها.

و على هذا الأساس، يتضح أنه بالنسبة لكل الفئة النشيطة الدين عملوا، لمدة ساعة واحدة 
على الأقل في الأسبوع سييلغ ^؛ ساعة في حين أن المعدل المتوسط هو ^ـ ساعة. وووفقا

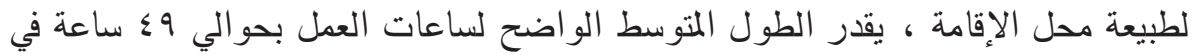

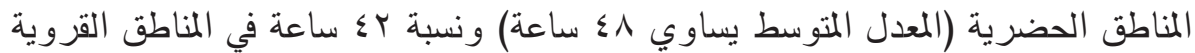

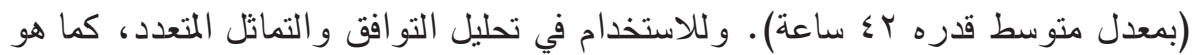

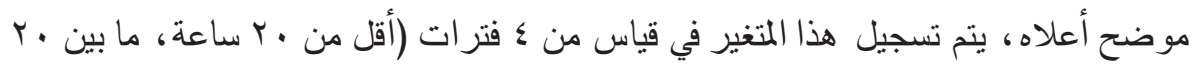

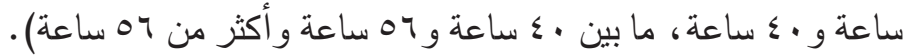

وو فيما يخص دوام العمل، فإن حوالي ^ץ ٪ من الأفر اد (النشيطين العاملين) أفادو ا أنهم

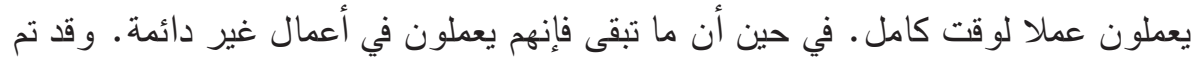

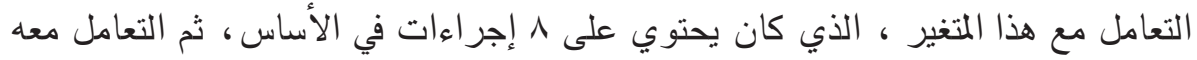

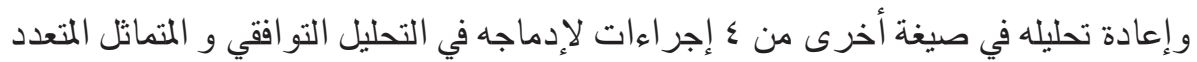

وبالنسبة لمسألة حيازة عقد عمل، وبالنسبة للأفراد الذين أجابوا على هذا السؤال (فقط الأل

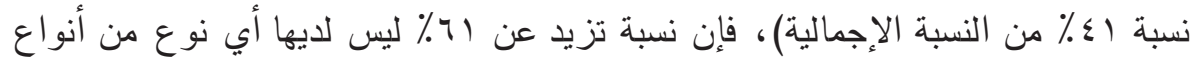

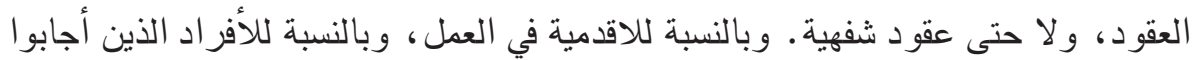

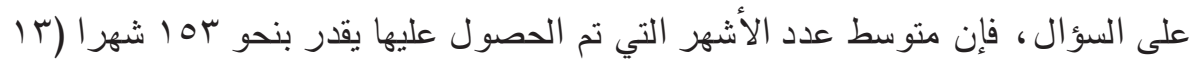

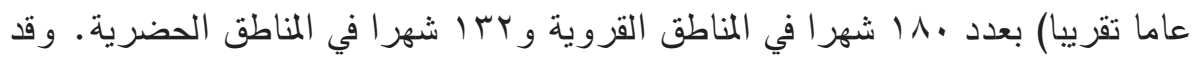

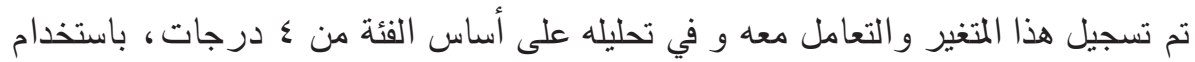

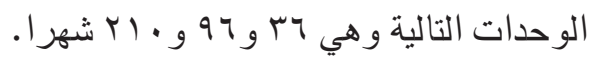

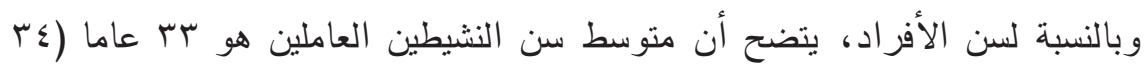

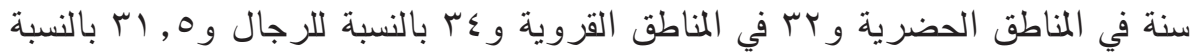

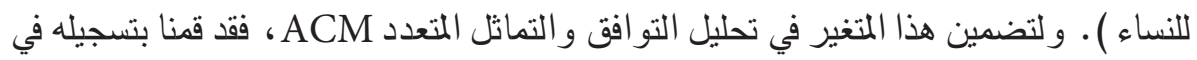

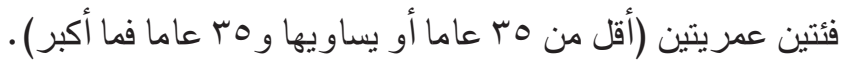

و بالنسبة للمتغير الخاص بوجو د قسائم رواتب ثابت للعمل لكافة الأفر اد، فإن نسبة قدرها

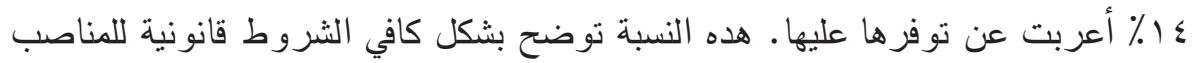

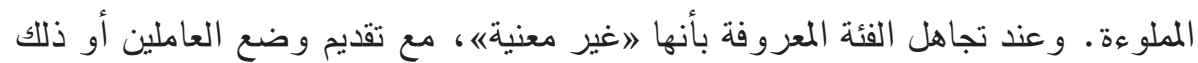

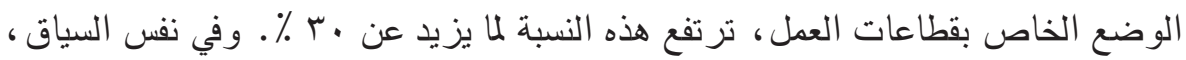


فإن نسبة العاملين الذين قالو ا إنهم تابعين لصندوق للضمان الاجتماعي نسبة ب ا ٪. و ولتناول

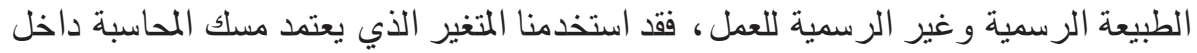

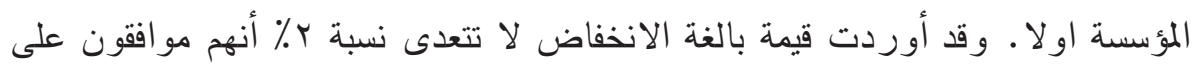

ولتقييم مستوى الرضا عند العمال بصورة مباشرة، توضح مسألة تغيير العمل أن نسبة

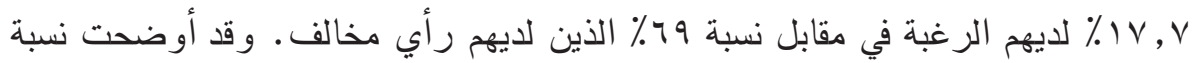

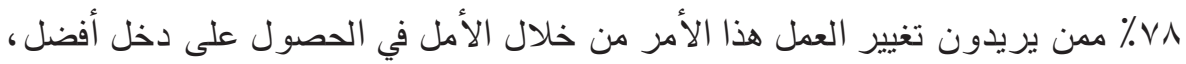

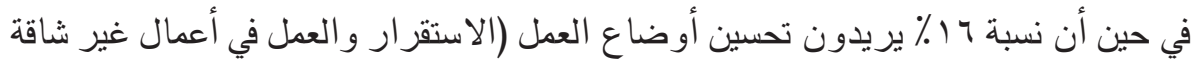

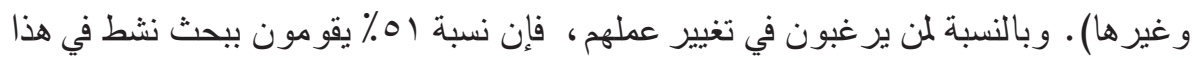

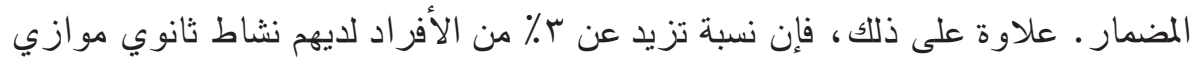

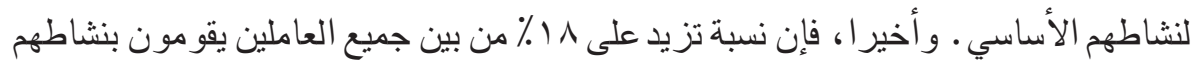

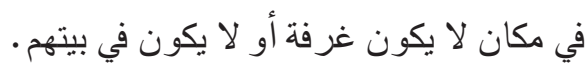

وطبقًا لقطاع النشاط، فقد قمنا لأغر اض هذا التحليل بتجميع الاجر اءات في قسمين هما:

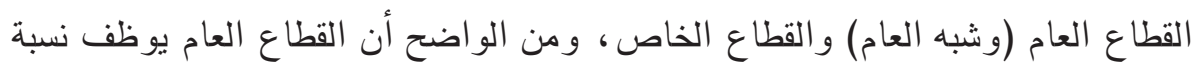

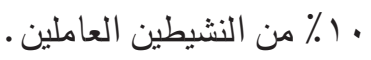

ولكي نجري مقارنات ذات صلة، خاصةً في إطار جو دة العمل والمتغير ات الخاصة التي

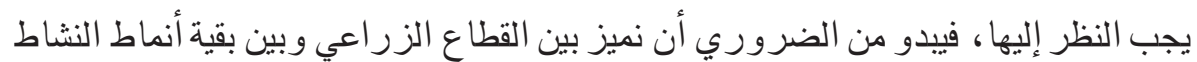

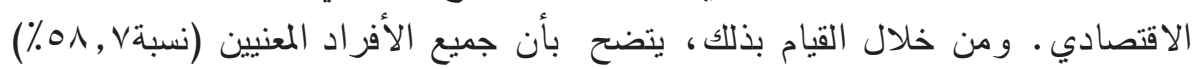

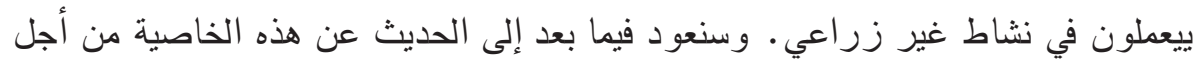
تحديد الساكنة المر جعية في تحليلن فئ.

\section{r/0 تحيل التوافق والتماثل المتعدد ووضع مؤشر جودة العمل:}

بعد إجر اء العديد من الاختبار ات ولأغر اض الاتساق و المقارنة، السكان التي تم اعتمادها

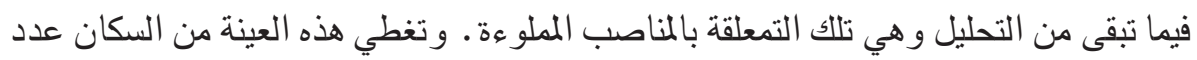

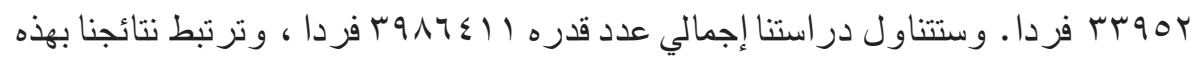

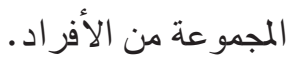




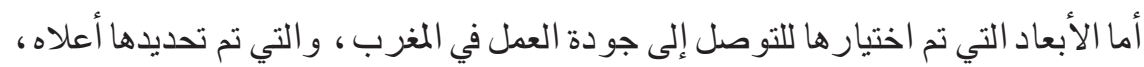

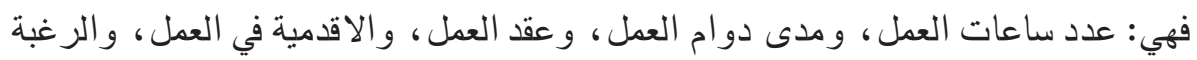

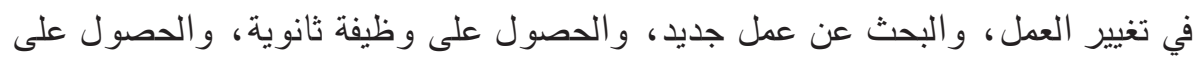

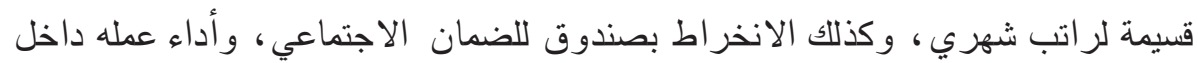

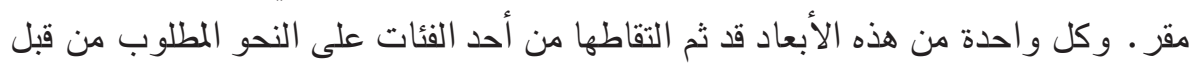

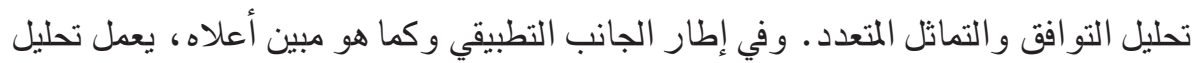

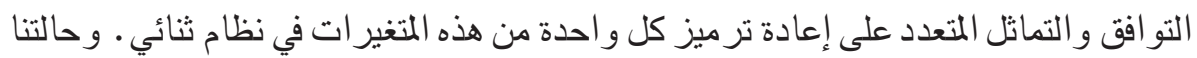

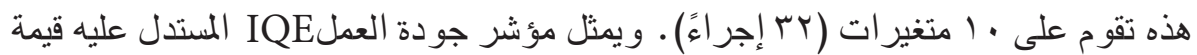

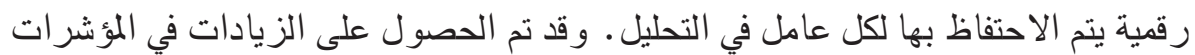
الأولية بأسلو ب موضو الاحيفاطي من خلال تحليل التو افق و التماثل المتعدد.

شكل رقم (1): قيم تحليل التوافق والتماثل المتعدد

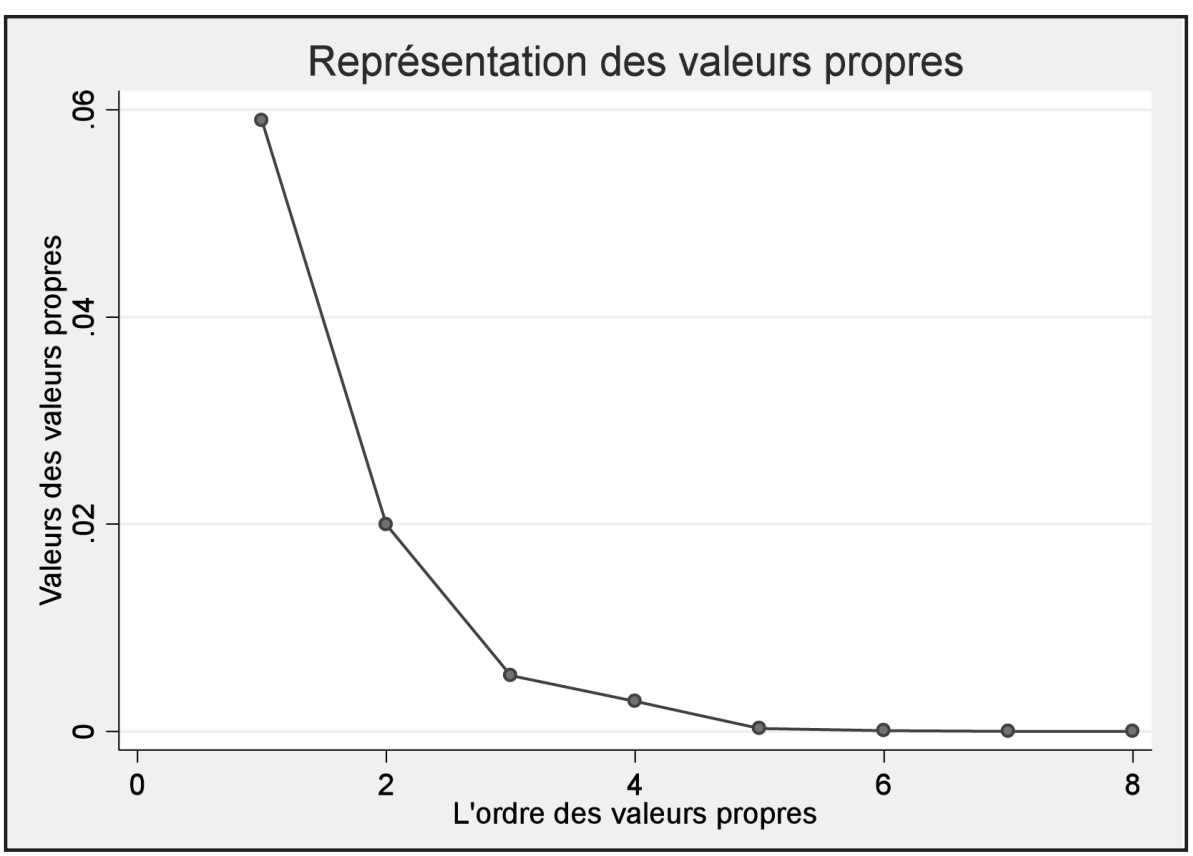

المصدر: البحث الوطني للثشل 1999 المثيم)

(تشثيل القيم - ترتيب القيم) البحن 
ويوضح الثكل الأول أدناه التمثيل البياني لقيم تحليل التوافق والتماثل المتعدد التي يتم

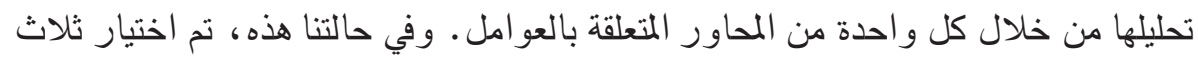

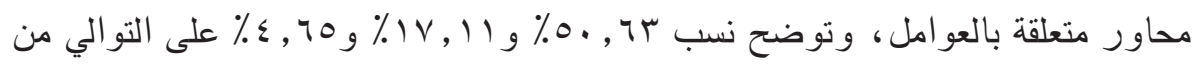

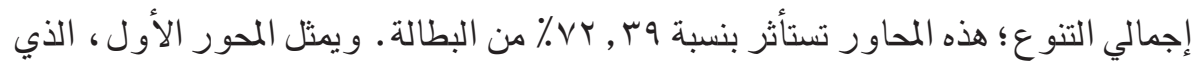

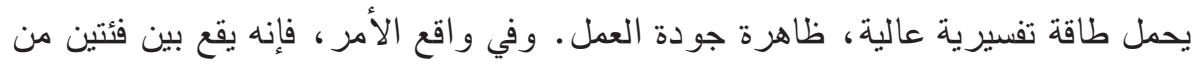

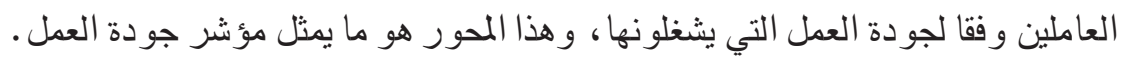

الثكل رقم (ץ): مخطط توزيع التواتر للمؤشر المعدل بالكثافة لجودة العمل (مؤشر

(IQE Tودة العمل

Histogramme de l'indicateur ajusté de la qualité de l'emploi (IQE*) Actifs occupés non agricoles du milieu urbain

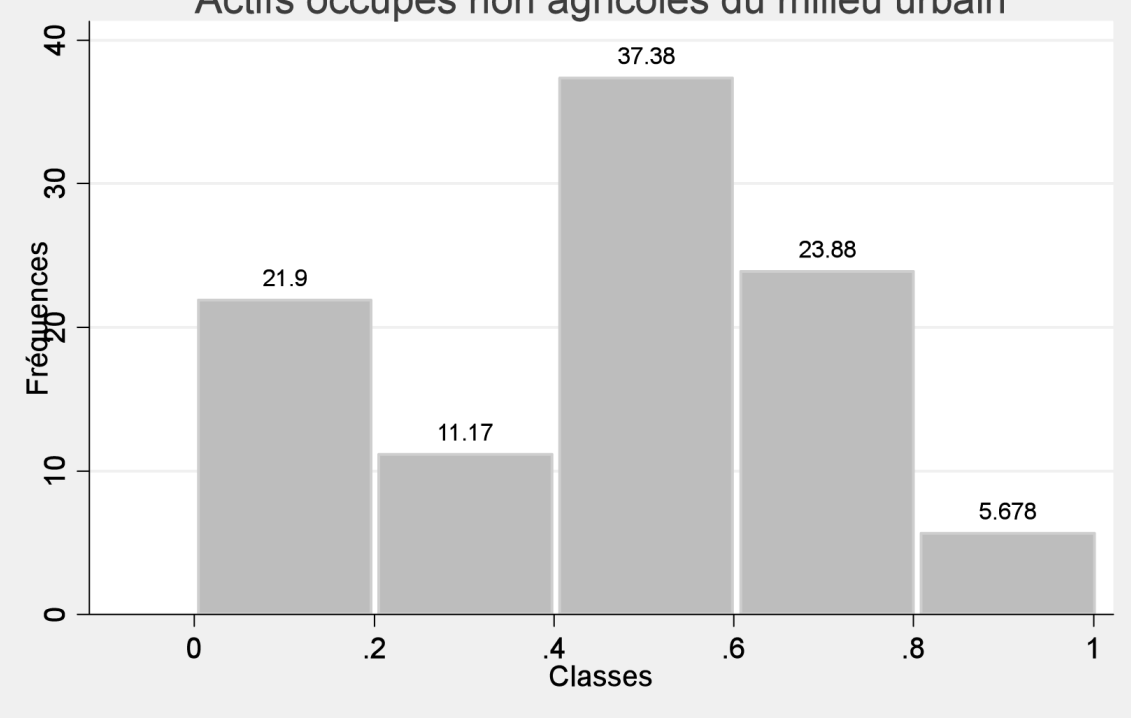

المصدر: المسح الوطني للتوظيف، 1999 


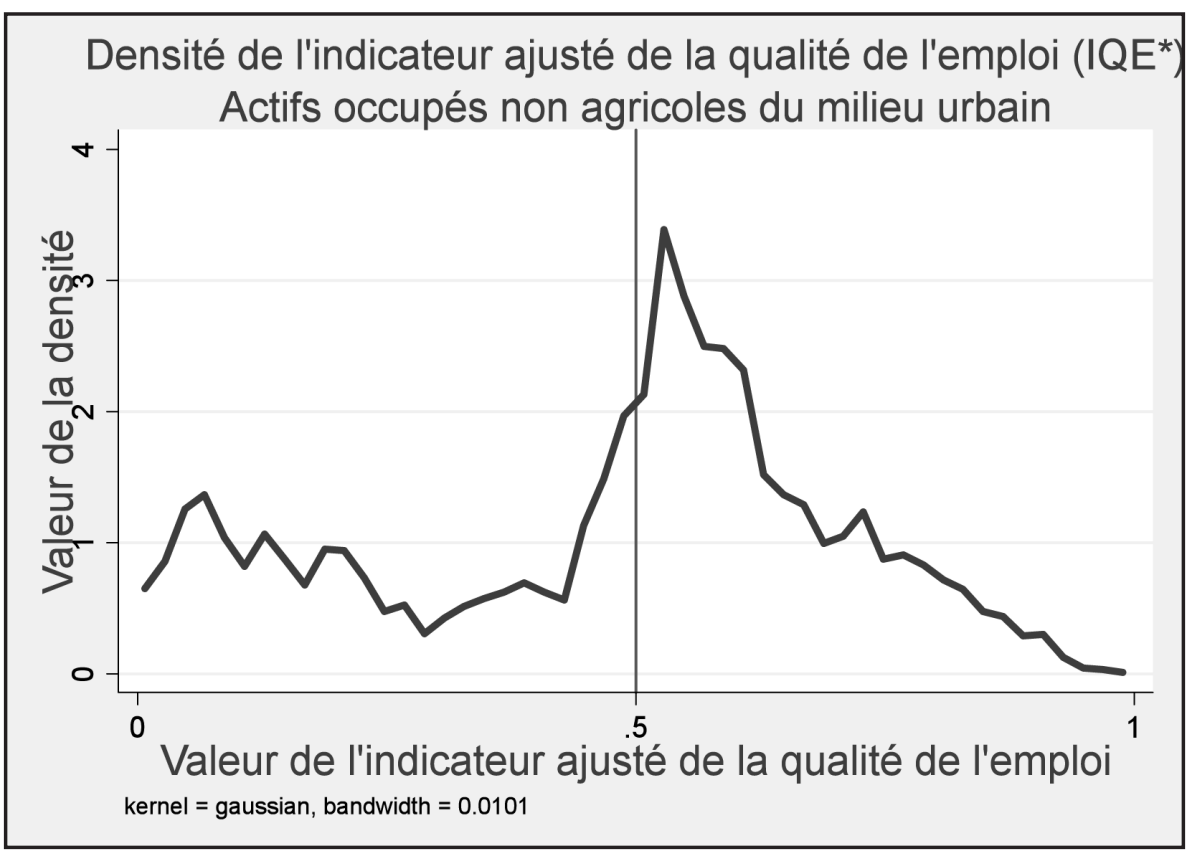

المصدر: البحث الوطني للشغل، 1999 مخطط توزيع التواتر للمؤشر المعدل بالكثافة لجودة المؤ العمل

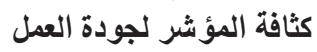

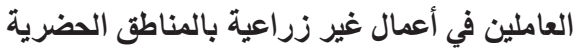

وتوضح نفس الرسوم البيانية والاختبارات التجريبية أن المتغيرات المستخدمة في تحليل التو افق و التماثل المتعدد لدينا تقدم معلومات خاصة عنها ، وتتعلق بملكية و COPA ـ و لذلك فنحن لسنا بحاجة إلى إجر اء صورة أخرى من تحليل التو افق و التماثل المتعدد. . ويحمل المحور الأول فيها فصلا يقوم على جودة العمل بالنسبة للعاملين في الوسط الحضري في نشاط غير زر اعي • و الأفر اد الحاصلون على أعلى القيم فى هذا المحور هم من يعملون في وظائف سيئة و العكس بالعكس. و وتظهر القيمة المتوسطة لمؤشر جودة العمل على أنها تساوي صفر تقريبا،

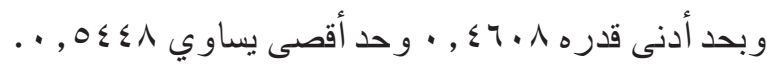

وكما نلاحظ من خلال إتباع تحليل التو افق و التماثل المتعدد على المتغيرات المتتارة، فإن قيمة مؤشر جودة العمل لكل فرد عامل يمكن أن تكون إيجابيا أو سلبيا. و ولأغر اض التو التوضيح و دون فقد أي معلو مات أو التعميم، فإنتا نستنتج قيمة مساوية للقيمة الايجابية التي نستخدم من فن 
خلالها مؤشر جودة العمل في تحليل إضافي . وبالنسبة لكل فرد، تساوي قيمة مؤشر جودة

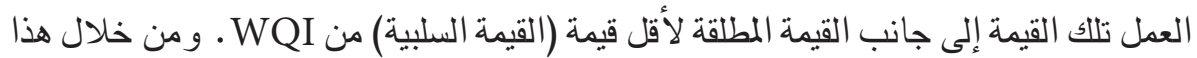

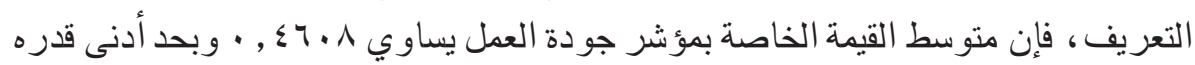

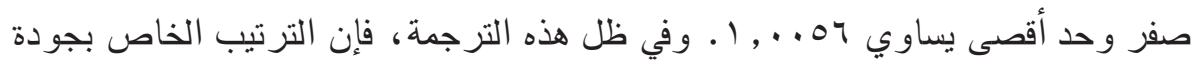
العمل للأفز اد العاملين يظل بلاوي تغيير .

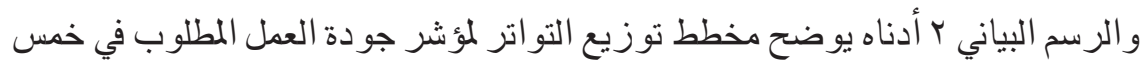

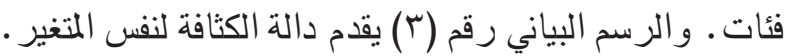

9: انظر الجدول A باللمق - معطيات كل الاجر اءات للمتغيرات المستخدمة في

المحاور الثلات

\section{قيمة مؤشر جودة العمل}

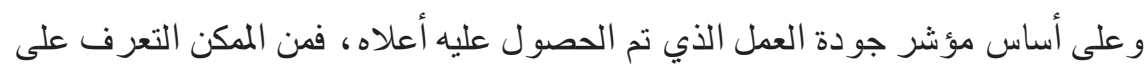

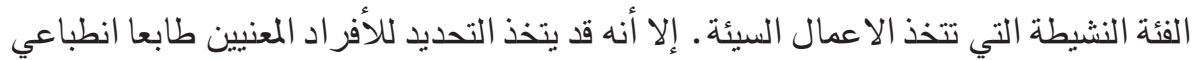

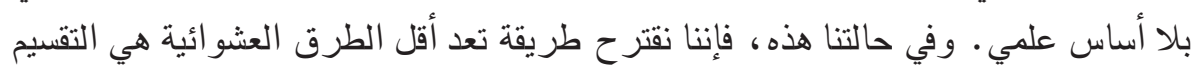

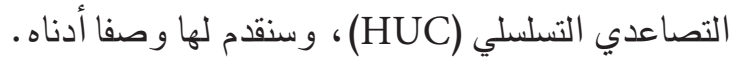

لجدول با: توزيع العاملين في المناطق العضرية غير الزراعية وفقا للجموعة وبعض جوان

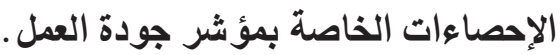

\begin{tabular}{|c|c|c|c|c|c|}
\hline هؤشر جودة الأقصى من & مؤشر جودة العدل الأدنى من & المتو سط من مؤشر العمل & النسبة المئوية & العدد الفعلي & المجموعة \\
\hline 0.48 & $\mathbf{0}$ & 0.106 & 23.46 & 935024 & المجموعة الأولى \\
\hline 0.77 & 0.086 & 0.443 & 24.42 & 973658 & المجموعة الثانية \\
\hline 0.95 & 0.206 & 0.588 & 19.94 & 794774 & المجموعة الثالثة \\
\hline 1 & 0.310 & 0.640 & 16.28 & 649061 & المجموعة الرابعة \\
\hline 1.01 & 0.289 & 0.671 & 15.9 & 633894 & المجموعة الخامسة \\
\hline 1.01 & $\mathbf{0}$ & 0.461 & 100 & 3986411 & الإجمالي \\
\hline
\end{tabular}

المصدر: البحث الوطني للشغل، 1999 


\section{P/ التقسيم التصاعدي التسلسلي وبناء فئات لجودة العمل}

يعتبر التقسيم التصاعدي التسلسلي أحد طرق جمع الفئة النشيطة العاملة في المجموعات

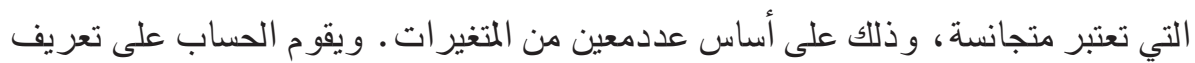

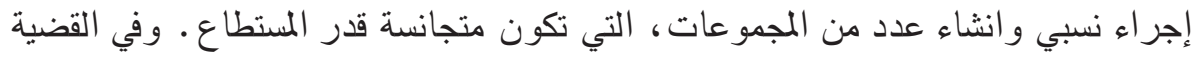

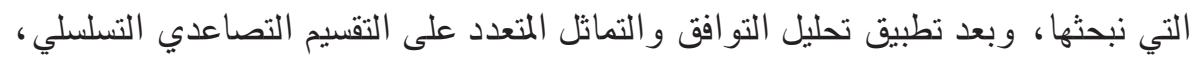

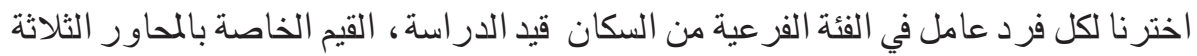

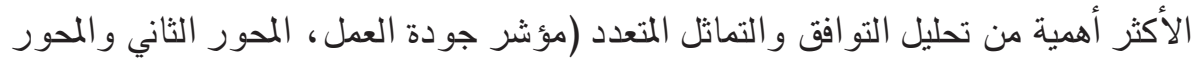
الثالث) . و الهدف من ذللك هو تطوير م فئات متجانسة من العاملي.

شكل رقم (؛): متو سطات المؤشر المعدل من جودة العمل حسب المجموعة

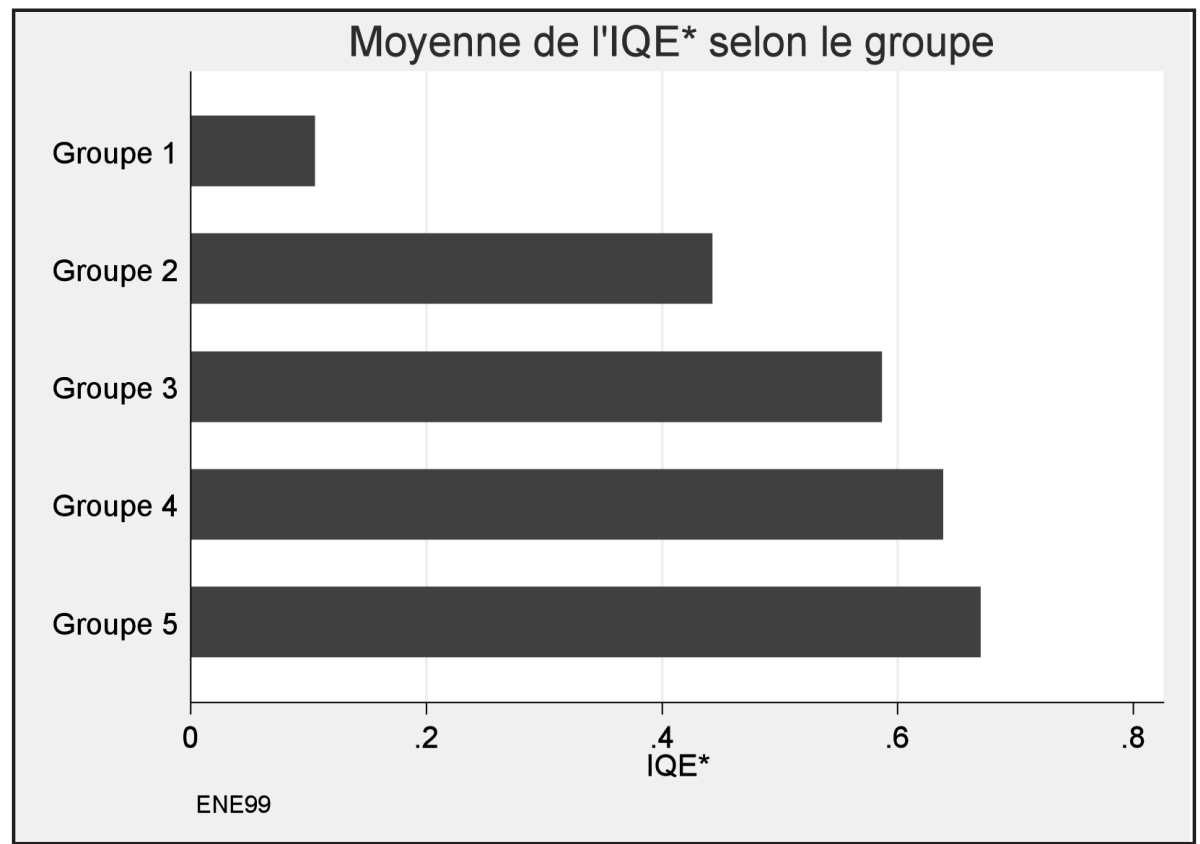

هؤ شر جودة العمل بالمجموعة بودئ متوسط مؤشر جودة العمل بالمجموعة بودة المصدر: البحث الوطني للثغل، 1999 
الثكل رقم (๑): التوزيع وفقا لمجموعة العاملين في المناطق الحضرية غير الزراعية

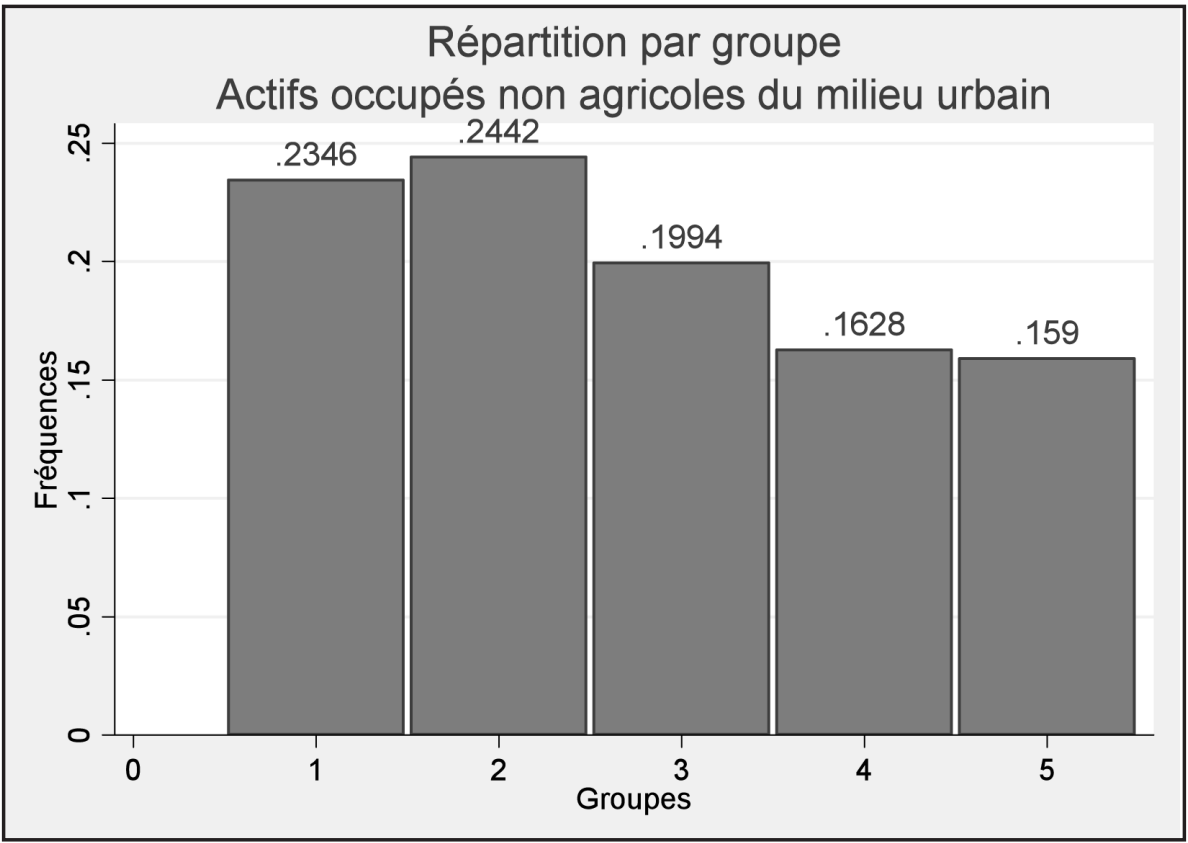

المصدر: البحث الوطني للثغل، 1999

إلا أنه عندما يتعلق الأمر بالممارسة الفعلية ولأغر اض الضوابط العددية ولعدد من القيود الرقمية الواضحة، لم يكن من الممكن تطبيقها في وقت واحد على عينة تقدر بعدد سبوه فردا ـ إضافة إلى ذلك، و لأجل تطوير فئات متجانسة و تقديم مقارنات ذات صلة، تم برمجة التقسيم التصاعدي التسلسي بعد ذلك في حلقة تشمل السكان النشطين، في إقليم من أقاليم المغرب ، من خلال تحديد المجمو عات الخمسة المر غوبة. ثم يتم تجميعها بعد ذللك على المستوى الوطني في كل اقليم، ويتم وضع تقسيم على أساس ذلك .

وكنتيجة لهذا التحليل، وبالنظر إلى الأفر اد الذين يتم تقسيمهم إلى المجموعة الخامسة على أنهم الأقل حظا في جودة العمل ، يتضح أن نسبة ج ا ٪ تقريبا من العاملين بالقطاع غير الزر اعي في المجال الحضرية، و فقا للاحصاء الوطني للشغل 999 19، أوضح ان 19 أي المئة يشغلون و ظائف سيئة (أكثر من . . . سبح فردا) . ويتم تقديم التوزيع العالمي في الجدول الوارد أدناه. و نفس هذا الجدول يوضح أن نسبة Vیء تقريبا من العاملين يشغلون مناصب يمكن وصفها 


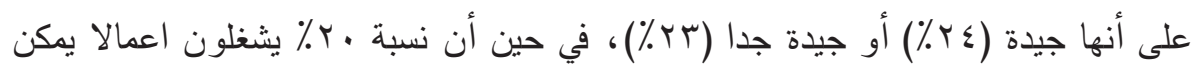

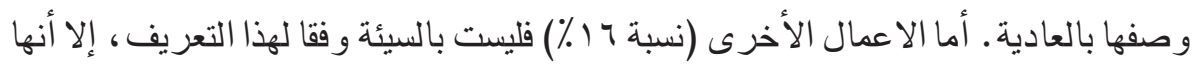

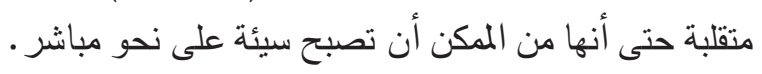

ومن أجل الحصول على صورة أفضل حول الوظائف السيئة، قمنا بجمع العاملين في

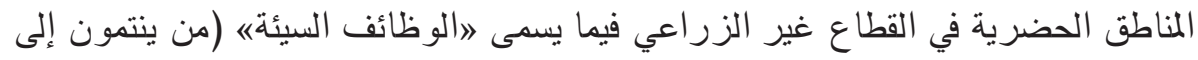

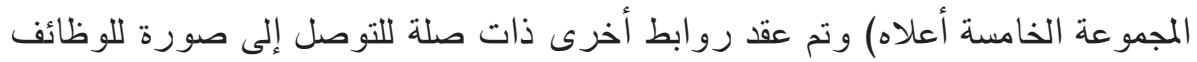
السيئة.

شكل (ا)): متوسط المؤشر المعدل لجودة الوظيفة من خلال المجموعة العمرية

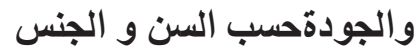
Moyenne de l'IQE* selon le sexe et la classe d'âge

masculin

Moins de 35 ans

masculin

Plus de 35 ans

féminin 0

.2

4

IQE*

masculin

féminin

ENE99

المصدر: البحث الوطني للثغل 1999 


\section{ه/ ما هي طبيعة الوظائف السيئة في المغرب ومن الأي يشظلها?}

تمثل الأسباب الكامنة ور اء حساب المؤشر ات المركبة لجودة العمل في السعي إلى ربطها

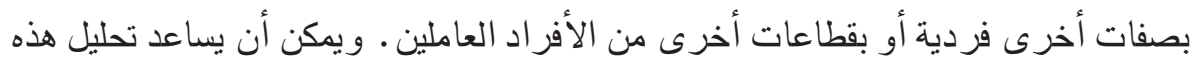
الروابط في وصف صورة الأعمال السيئة في المغرب.

شكل (V): تقدم المؤشر المعدل لجودة الوظيفة من خلال العر والنوع

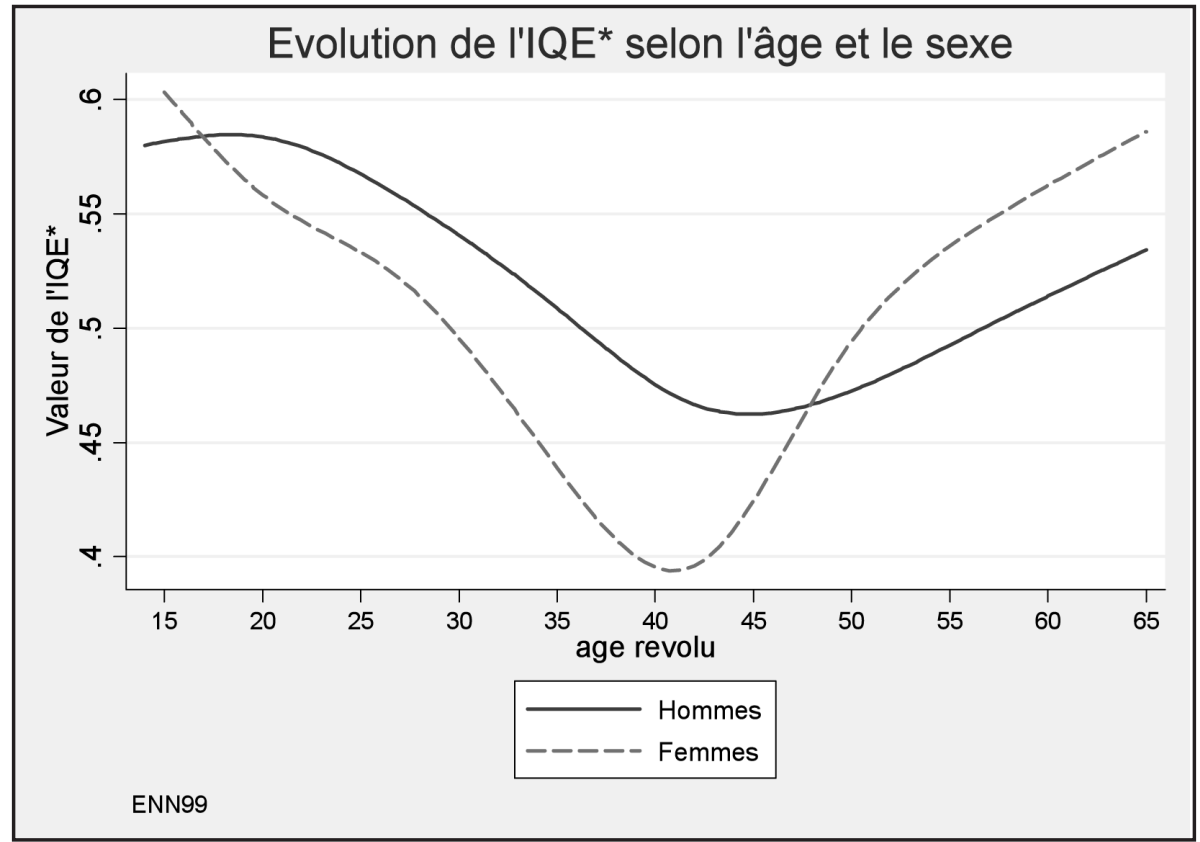

المصدر: البحث الوطني للشغل 1999

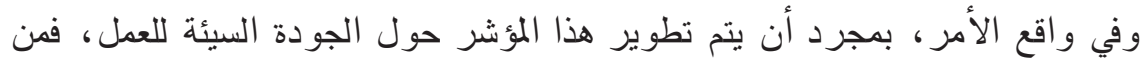

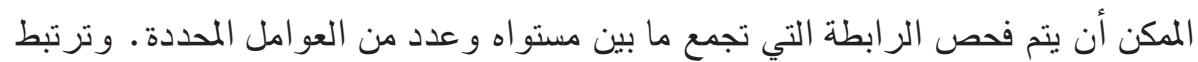

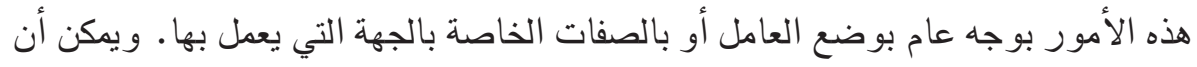

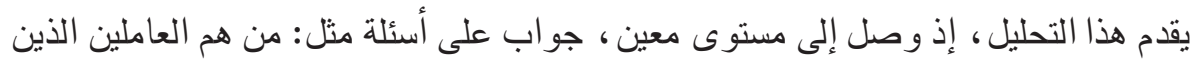

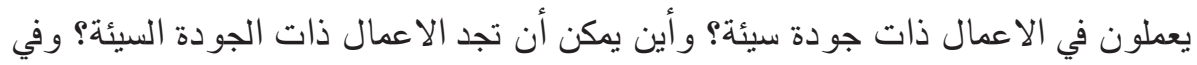

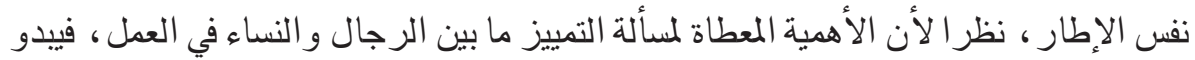

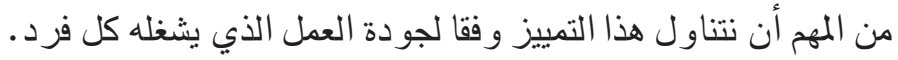


الشكل (^): متوسط المؤشر المعدل لجودة العمل طبقًا لمستوى التعليم والنوع

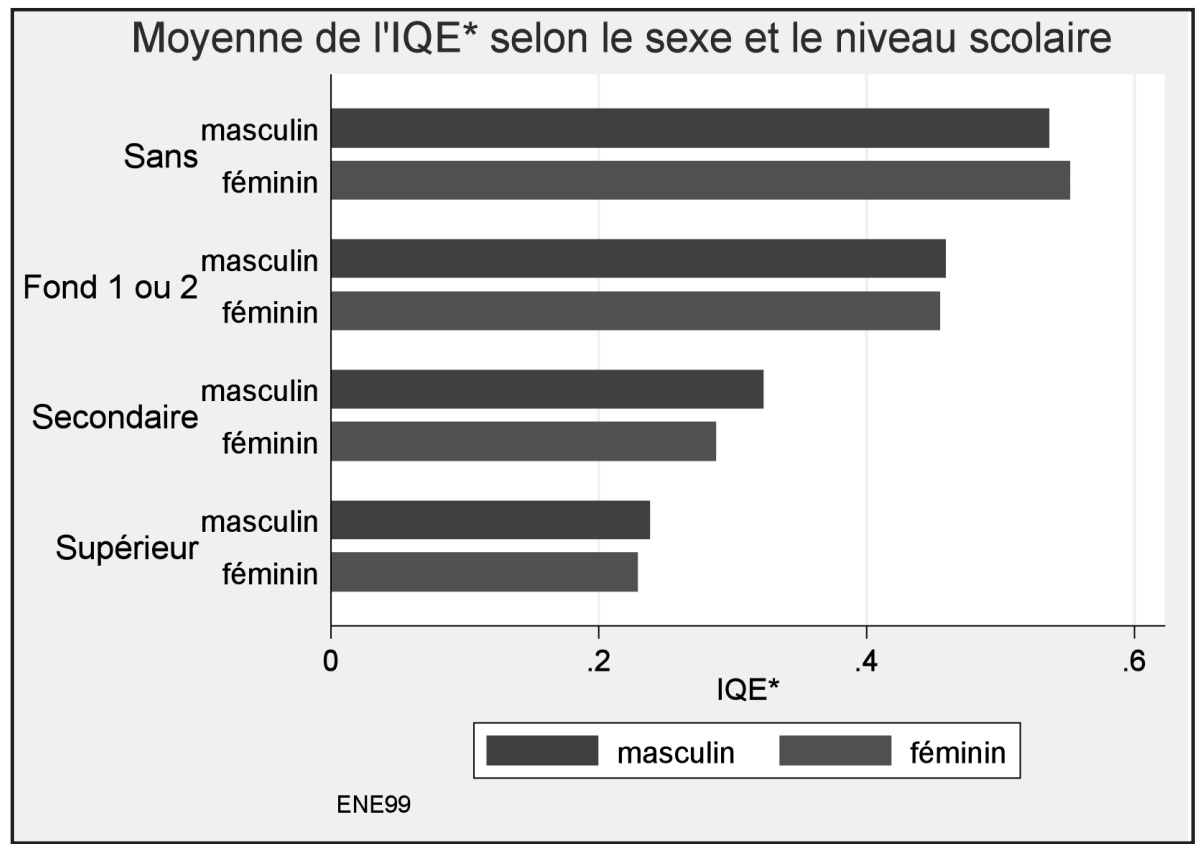

معدل مؤشر جودة الوظيفة في كل من النوع والدرجة العلمية المصدر: البحث الوطني للشغل 1999

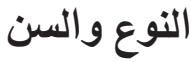

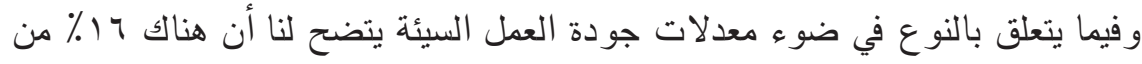

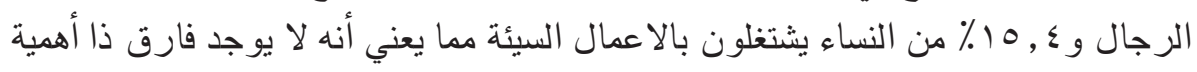

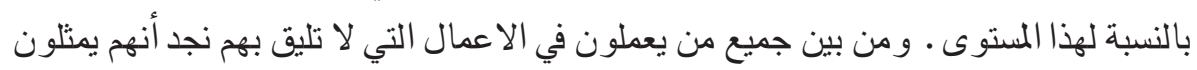

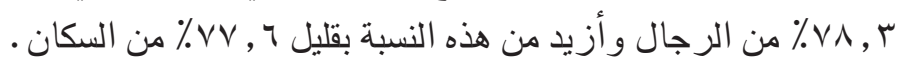

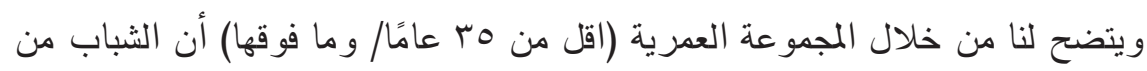

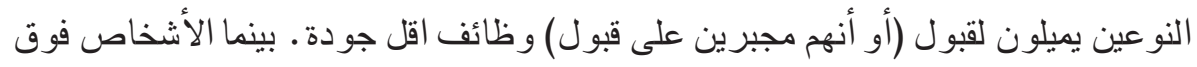

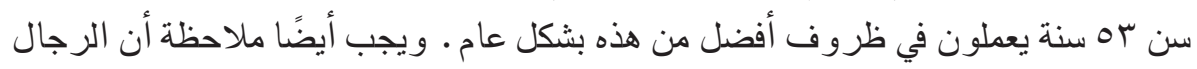

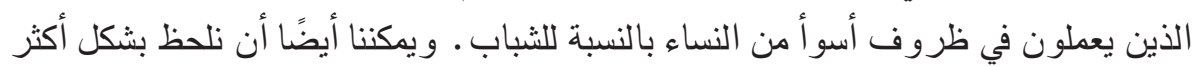

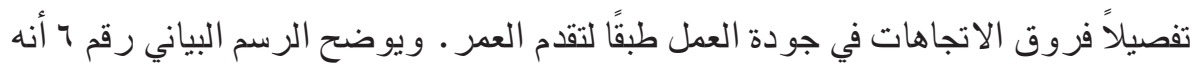

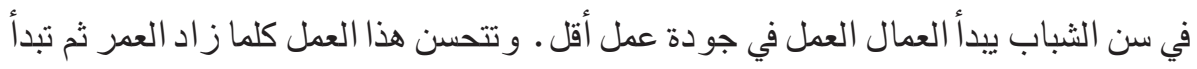

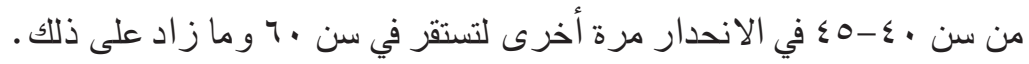


شكل (9): متوسط مؤشر جودة العمل اعتمادًا على الأوضاع والنوع

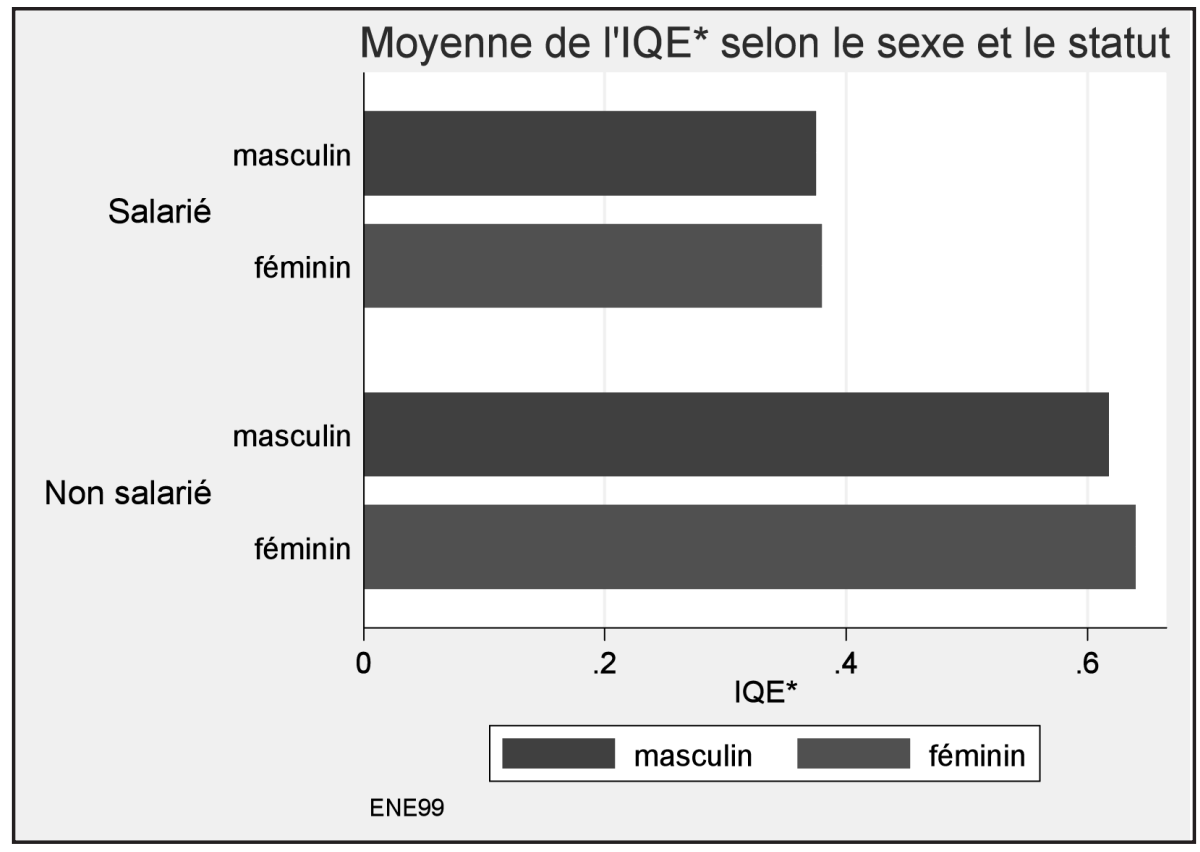

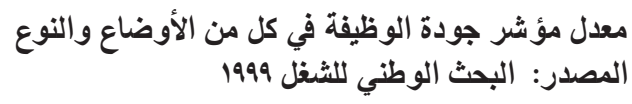

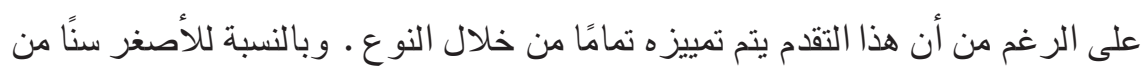

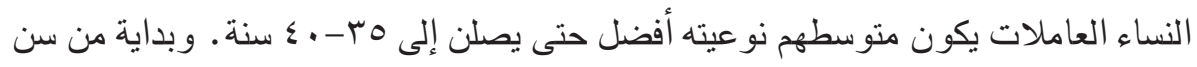

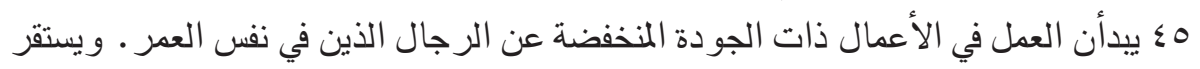
هذا الفارق بمرور عشر سنوات (أنظر الرسم البياني رقم لاع).

\section{التعليم و المستوى الدراسي}

ييين مستوى تعلم القر اعة و الكتابة اختلافًا في جو دة الوظيفة على الرغم من أن النساء من

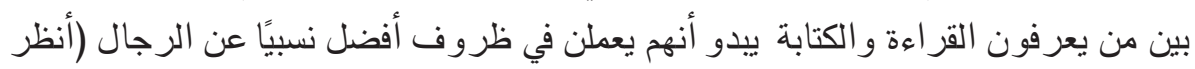

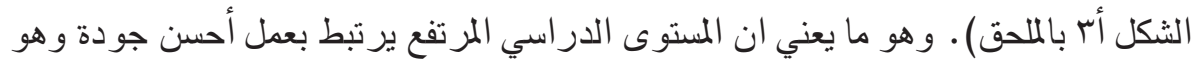

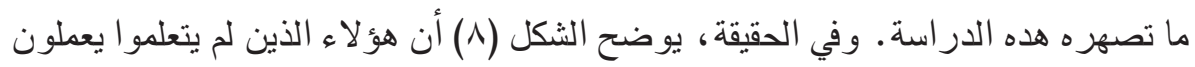

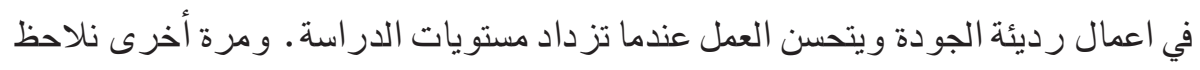
أن هناك فارق طفيف بالنسبة للنوع بالنسبة للفئة النشيطة العامل . 


\section{أوضاع الوظيفة}

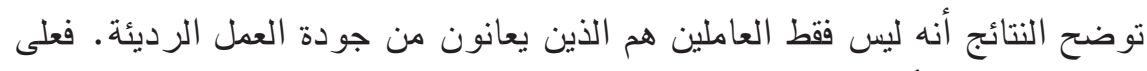

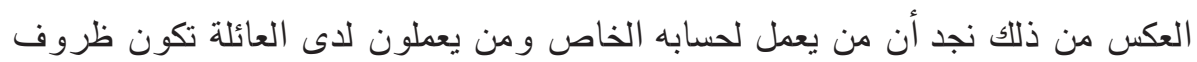

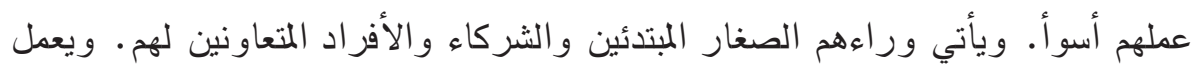

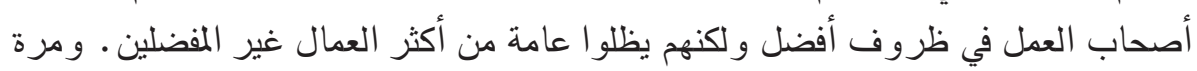

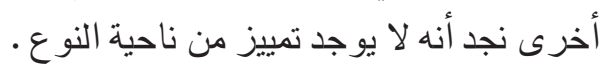

\section{المسئولية في العمل}

من الواضح أن العمال يعتبروا مسئولين عن التأكد من فائدة عملهم عن هؤلاء الذين

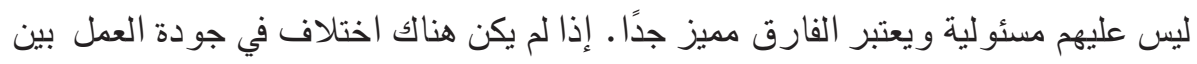

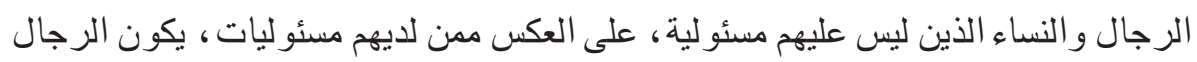

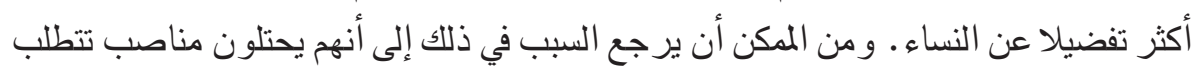

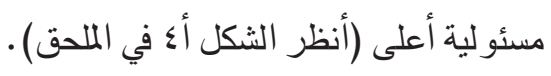

\section{الرغبة في تغيير العمل}

قد يبدو هذا المؤشر (السيئ) لجودة العمل غير مجدي حسب ما يرغب به العامل أو ألا

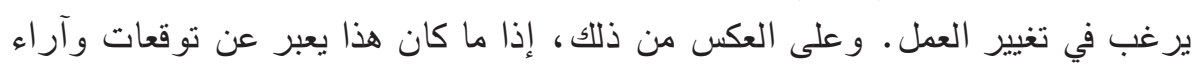

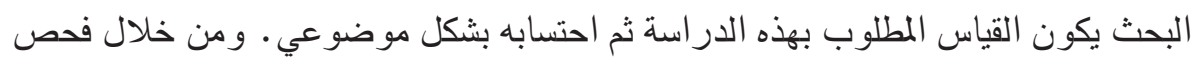

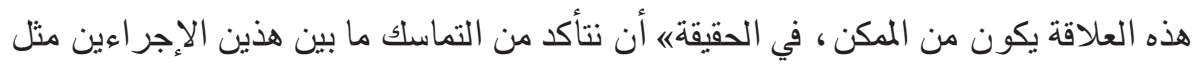

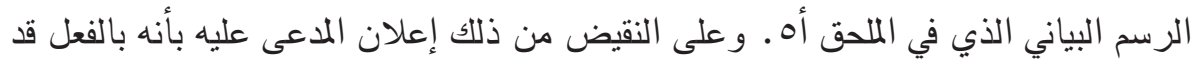

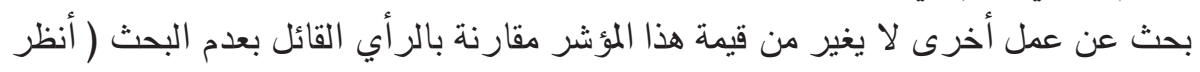

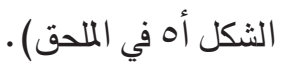

\section{قطاع العمل}

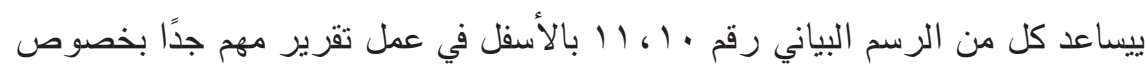

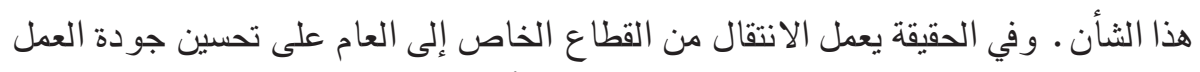

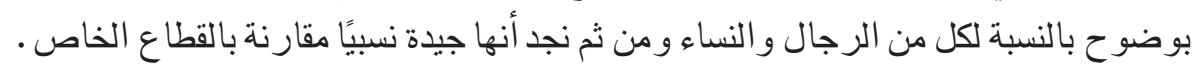

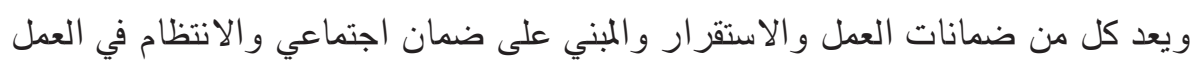


شكل (•1): متوسط المؤشر المعدل لجودة العمل من خلال قطاع الوظيفة والنوع

و العمر
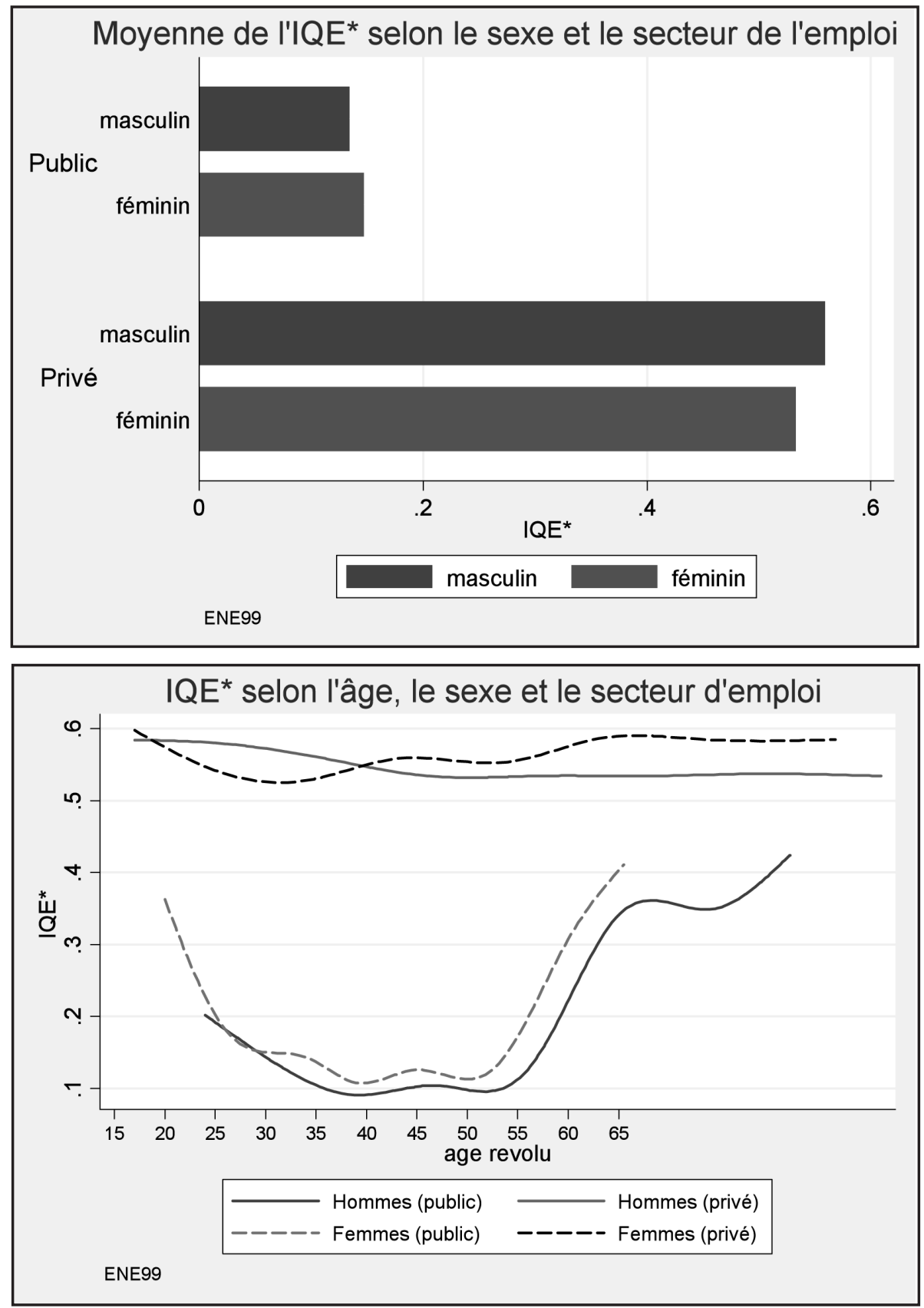

مؤشر جودة الوظيقة في كل من العمر و النوع وقطاع التوظيف 


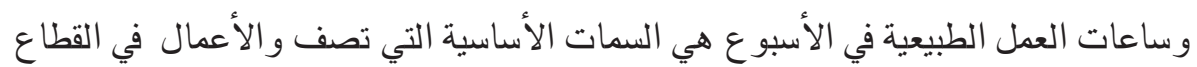

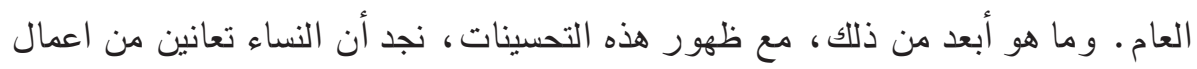

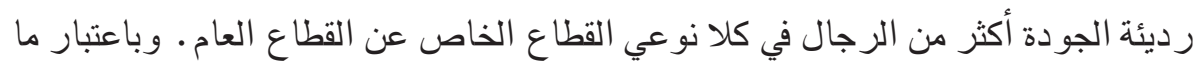

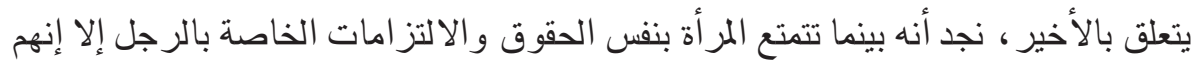

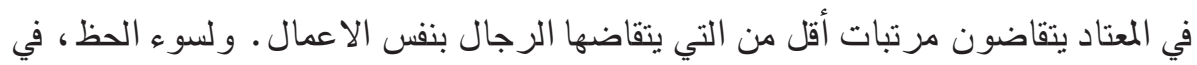

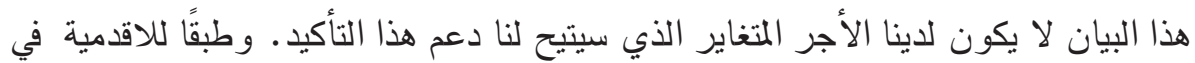

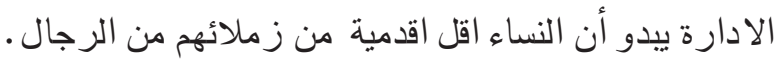

\section{القطاع غير الرسمي}

غغالبًا ما يتم تعريف القطاع غير الرسمي بالإشارة إما إلى غياب المحاسبة النظامية أو عدم

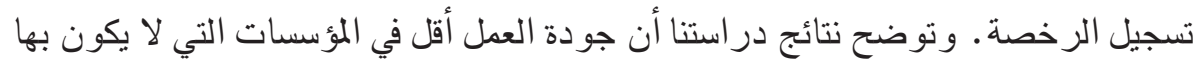

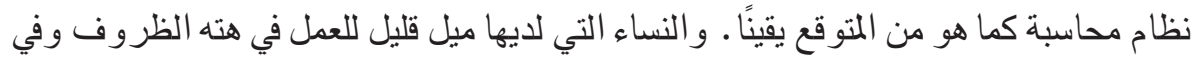

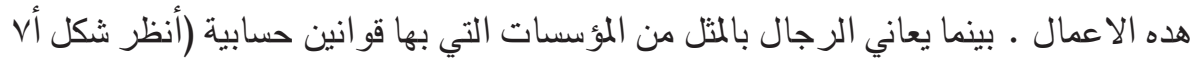
بالللحق) ( مده

\section{الضمان الاجتماعي}

إن تغطية الضمان الاجتماعي للعاملين يعد جزءًا من المعايير الأولى لتعريف جو دة العمل.

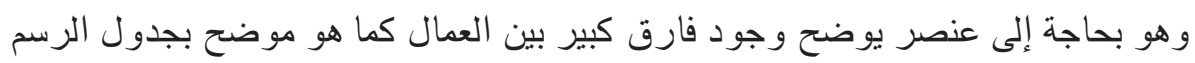

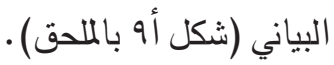

\section{حجم المؤسسة}

طبقًا لإجمالي عدد المناصب داخل مؤسسة العمل يتضح متوسط جو دة العمل تفاوت مهما

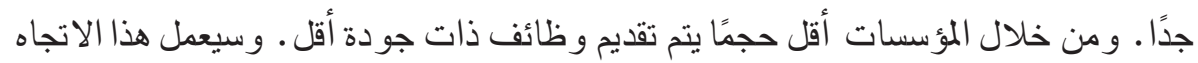

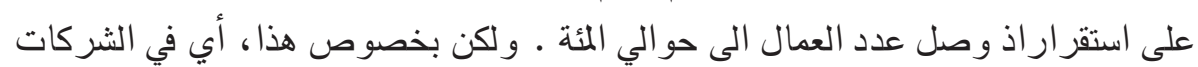

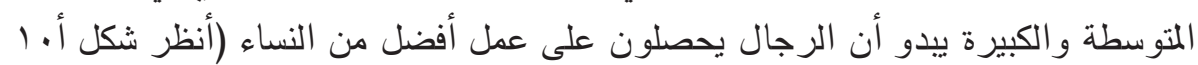

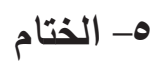

إن جودة العمل وموضوعه ومقاييسه قد أصبحت الثاغل الرئيسي للعديد من البلدان 
و المنظمات الدولة بما فيها منظمة العمل الدولية BIT. وقد تم إدر الك هذه الظاهرة في قاعدة

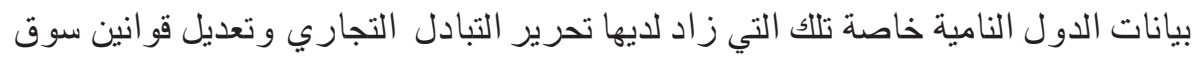

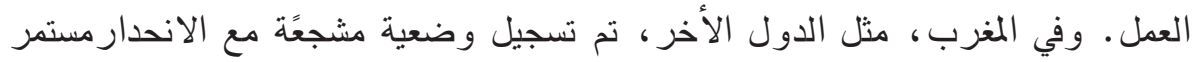

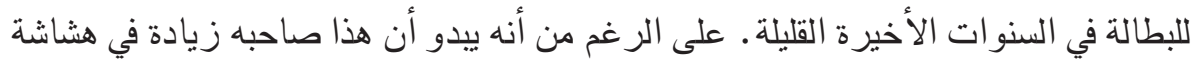

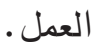

و في هذا العمل الدي هو الاول من نوعه في المغرب اعتمدنا على مجمل الكتابات الحديثة

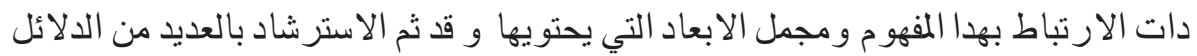
النظرية و التطبيقية لتبرير اللجوء الى المقاربة المتعددة الابعاد لقياس جو دة العمل.

وبناءً على هذا الاتفاق العام قمنا بوضع و بتفيذ المقاربة المتعددة الأبعادلجودة العمل

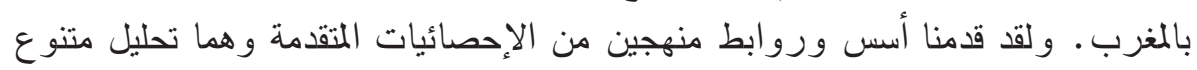

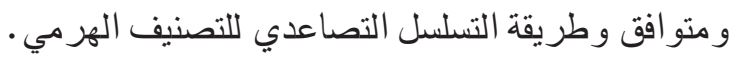

ولقد شرحنا أيضًا العملية التي صاحبت هذه المنهجية لتعريف الفئة النشيطة العاملة التي

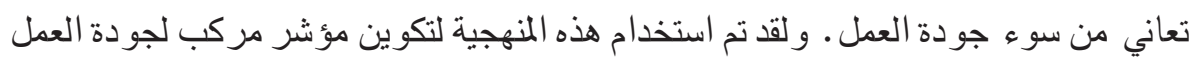
و الاي يمكن من خلاله تعريف المجمو عات الفرعية، و التي تجد نفسها في وضعية سيئة ه

ولأسباب ترجع إلى التماثل والمقارنة كان السكان الذين تم اختيارهم وأجريت الدراسة

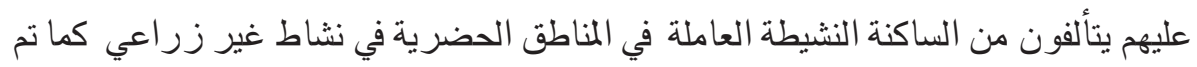

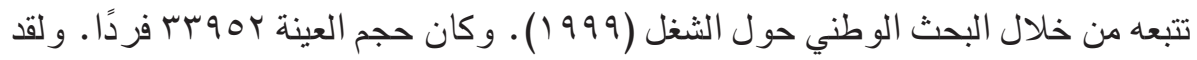

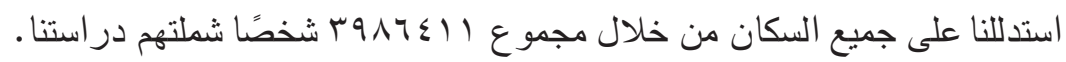

وفيما يتعلق بالنتائج الدقيقة وبصفتها سجل بياني للفئة النشيطة العاملة التي تعمل باعمال

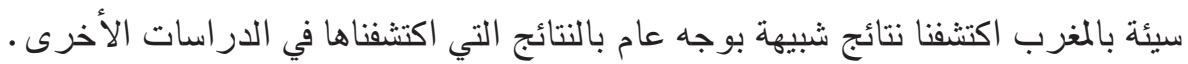

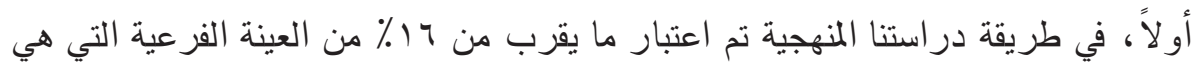

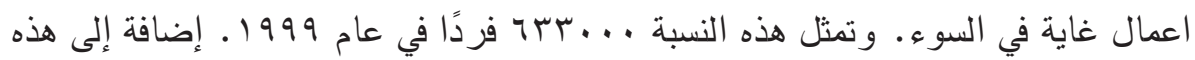

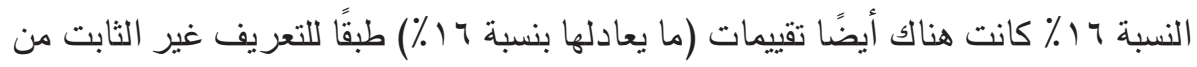

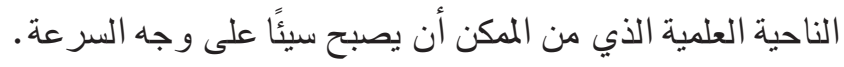

و على المستوى العام بخصوص جودة العمل، من الواضح أن الرجال و النساء يعملون 
بأعمال رديئة. ولم يتم تسجيل أية فروق إحصائية ذات أهمية. و من بين جميع من يعملون

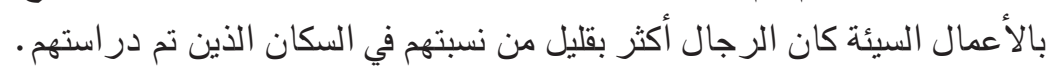

وبالاعتماد على المجموعة العمرية يتضح أن الثباب من كلا النو عين يميلون (أو أنهم

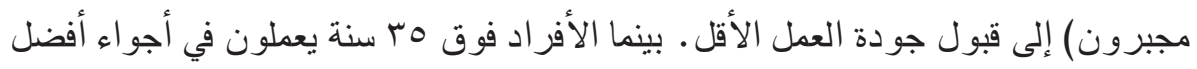

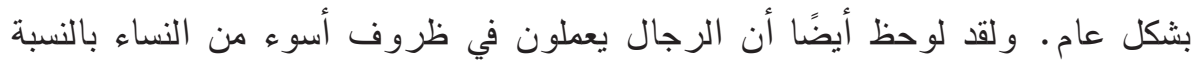
اللثباب.

وبمعنى آخر ، وطبقًا لما تنص عليه دورة العمل من الواضح أن جو دة العمل تبدأ بكونها

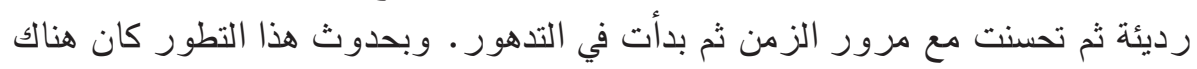

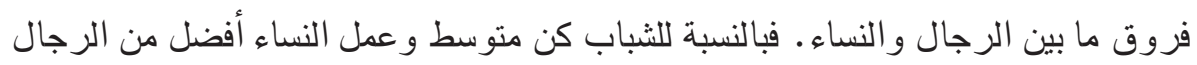

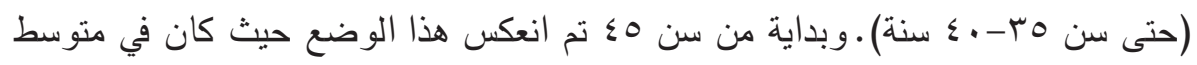

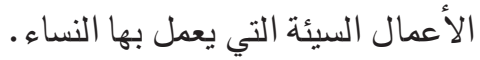

و ما يتضح بشكل عام هو أن من العمال الذين يعر فون القراءة و الكتابة وخريجي المدارس

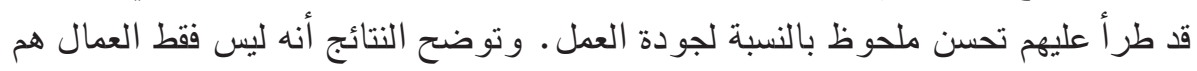

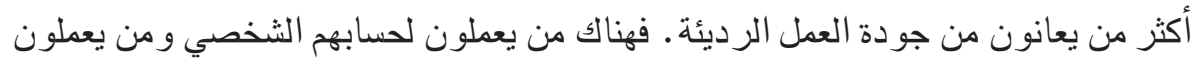

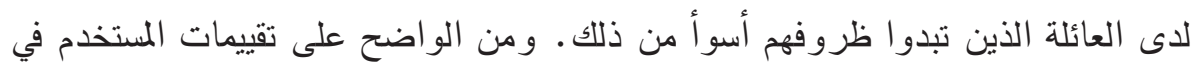

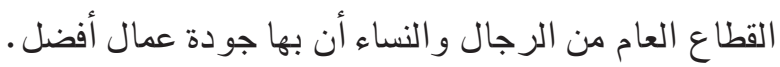

وبناءً على هذه الدراسة، كان السجل البياني الذي به عمل رديئ هو بالنسبة للثباب أقل

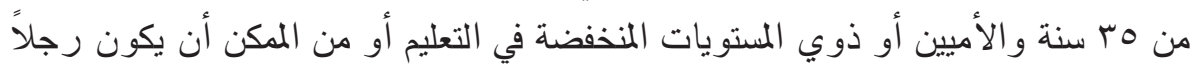

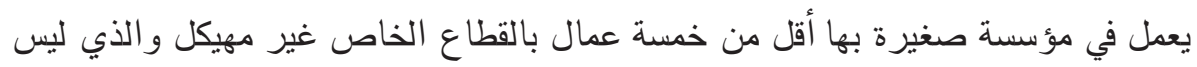

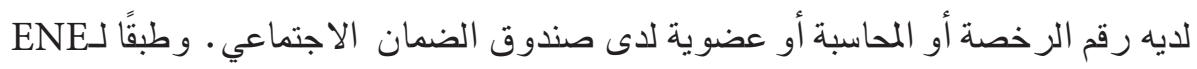

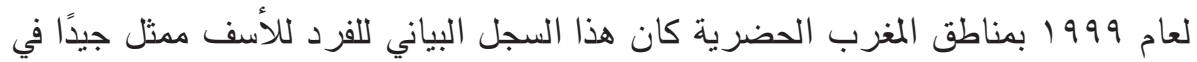

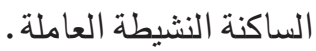

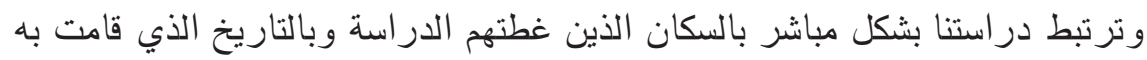

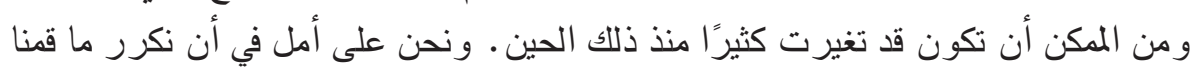

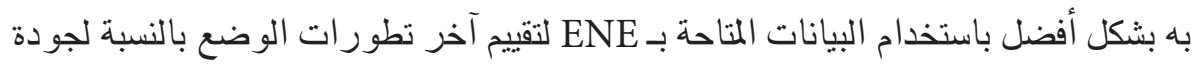

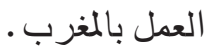




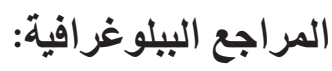

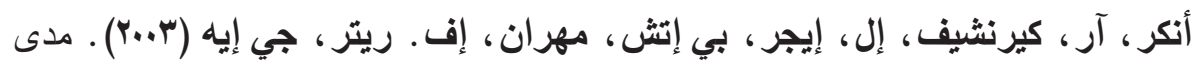

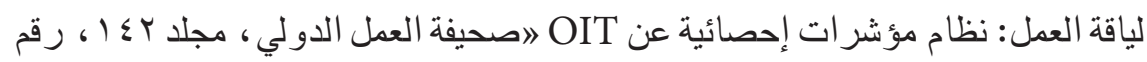

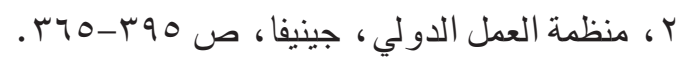

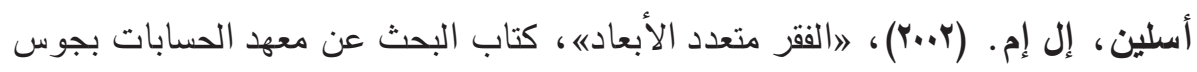

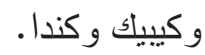

أسلين، إل إم. (؟..r))، (امؤشر تركيبي على نظرية الفقر متعددة لأبعادالنظرية CRDI

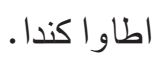

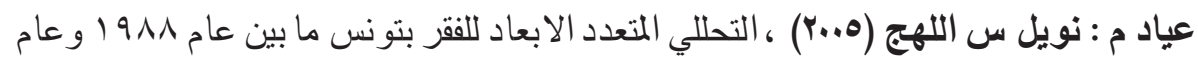

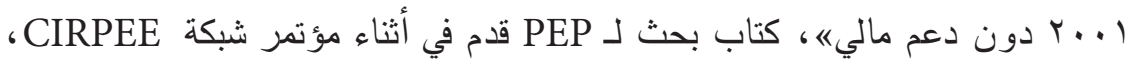

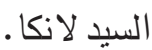

بنذكري، جي بي ، (19VY) ، تحليل البيانات، مجلد رقم ץ: تحليل الأشياء المتثابهة، ديونو د،

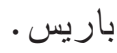

برتير، بي. ، بوروتث، جي إم، (19v0)، تحليل البيانات متعددة الأبعاد، PUF،

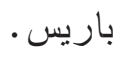

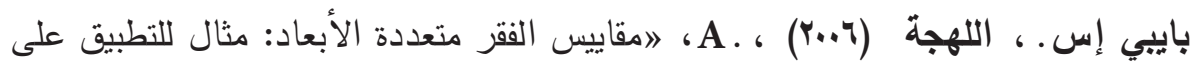

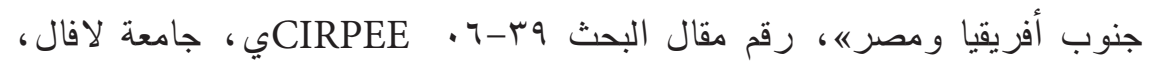

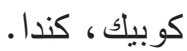

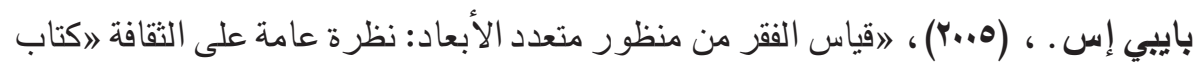
بحث لكيربي، جامعة لافال ، كوبيك، كندا.

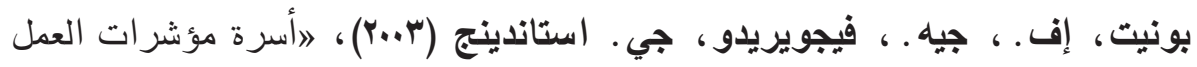

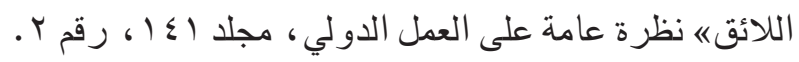

بورجويجنون، إف. ، تثاكرافارتي، إس آر (ץ..ץ)، ، (قياس الفقر متعدد الأبعاد) صحيفة

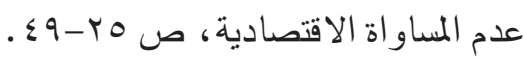




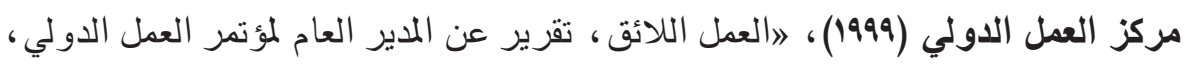

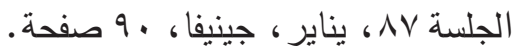

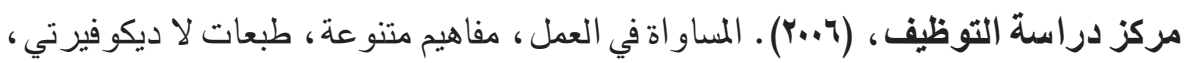

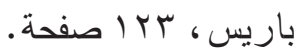

كلارك، إيه إي، (1991). مقاييس الرضا بالعمل: ما الذي يجعلها وظيفة جيدة؟ دليل من

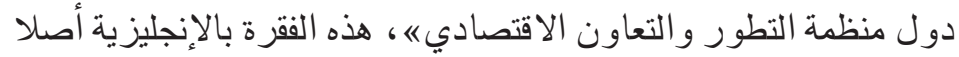

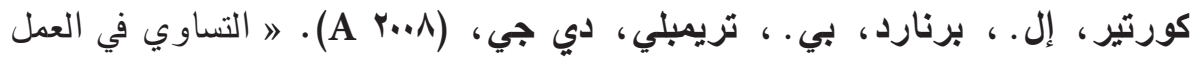

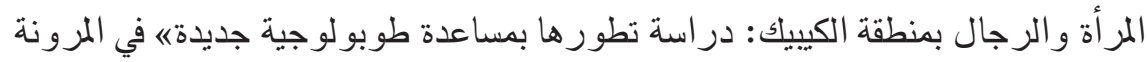

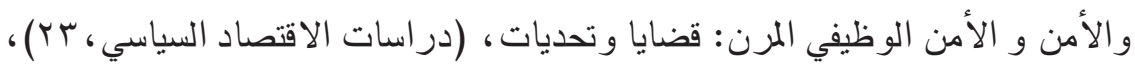

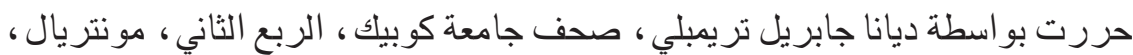
(1)

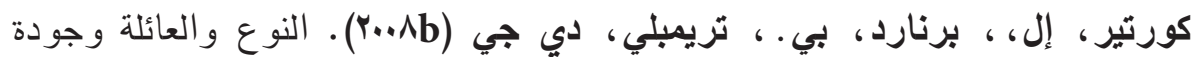

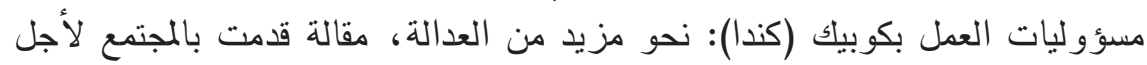

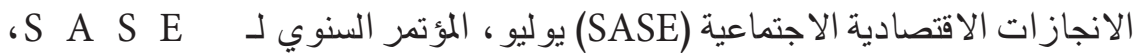
كوستا ريسا.

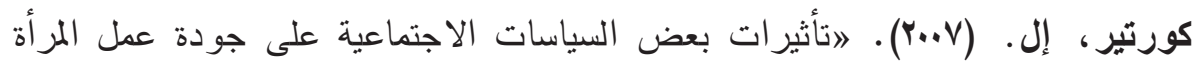

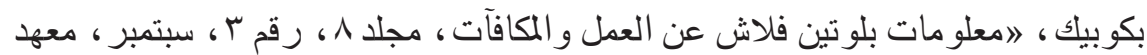

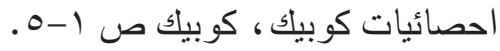

البعثة الأوروبية، (ب.(Y). \اتصالات من البعثة إلى المجلس، البرلمان الأوروبي، أقاليم

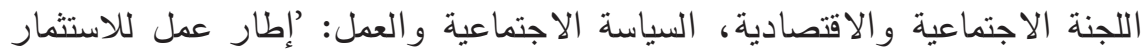

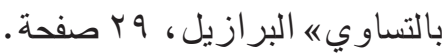

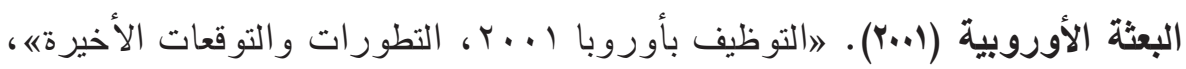

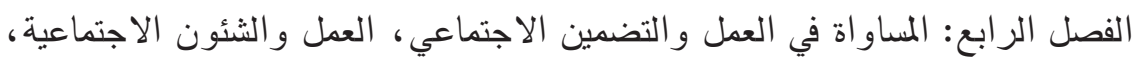

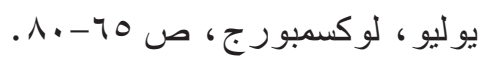




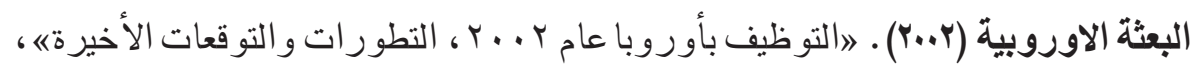

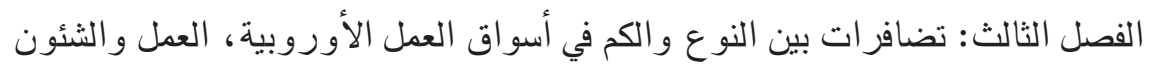

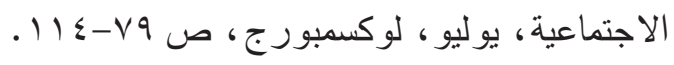

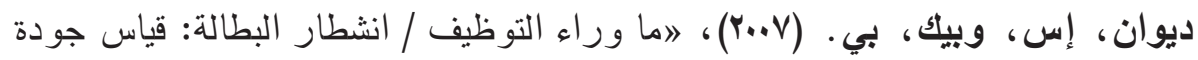

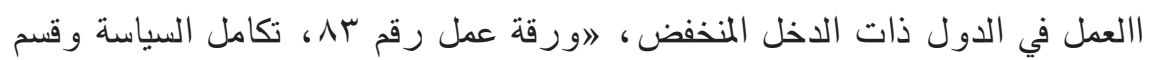
الإحصائيات ، مركز العمل الدولي ذات الاخل المنص

دروليت، إم. ، موريسيت، آر. (1991). االبيانات الكندية الأخيرة عن المساواة في

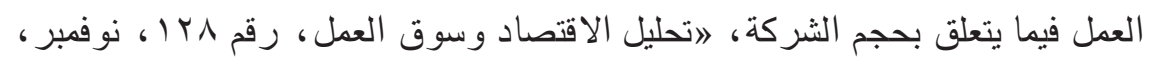

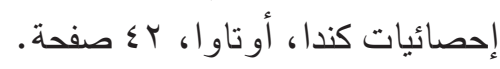

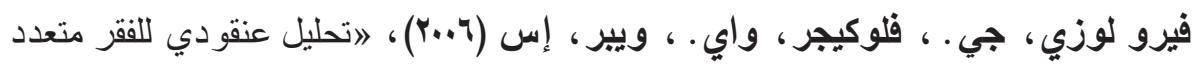

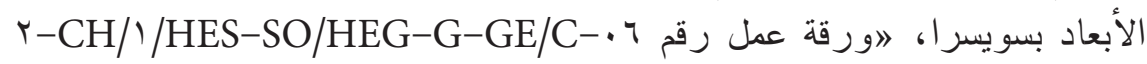
إدارة المدارس الثانوية بجينيفا.

المؤسسة الأوروبي لتحسين المعيشة وظروف العمل (ץ.بץ). "جودة العمل ، العمل

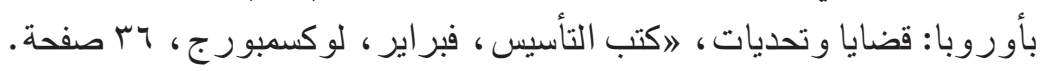

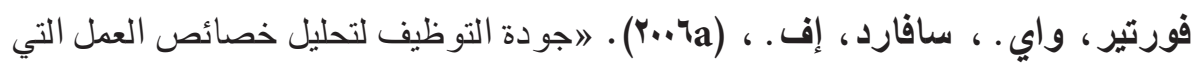

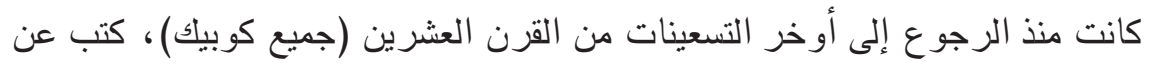

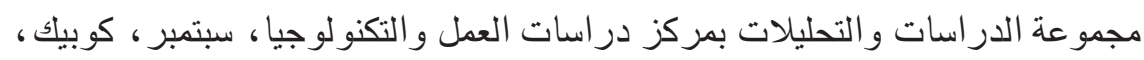

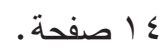

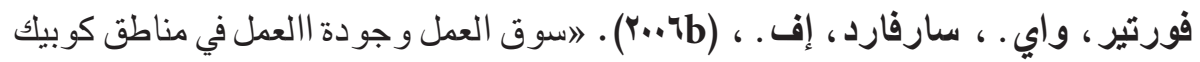

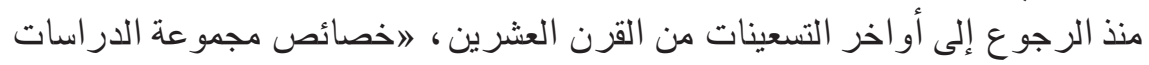

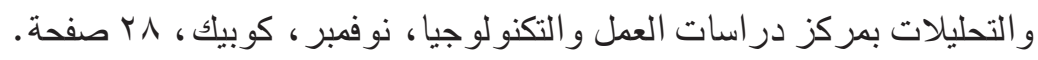

فريمجاكسي، ’إف. و لاهورتي، واي. ، "جودة العمل بفرنسا: الميول والدورة)، ورقة عمل، رقم 


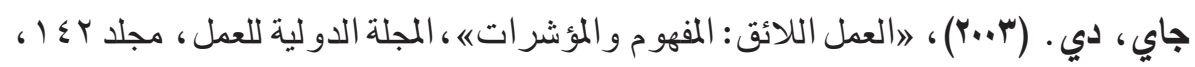

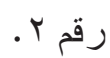

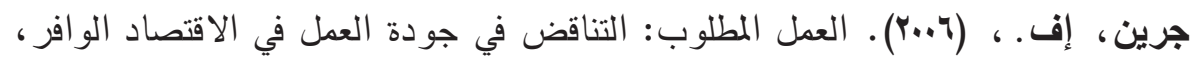

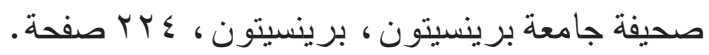

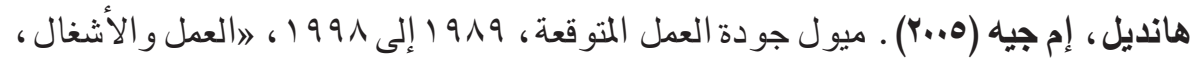

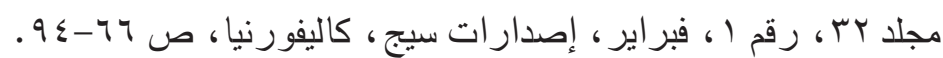

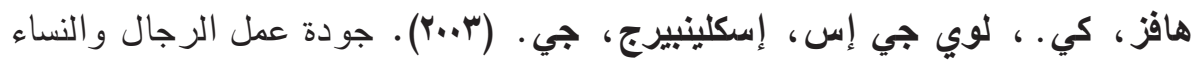

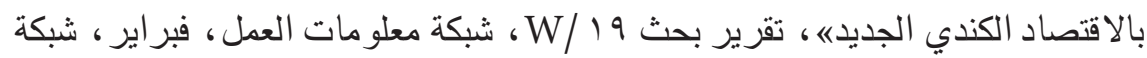

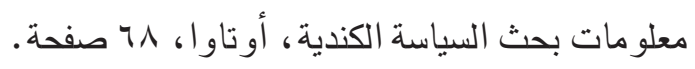

معهد إحصائيات كيبيك (ب.0) ، "جودة العمل في التطورات التصورية وخلق طوبولوجية

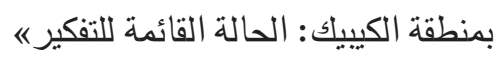

جامبو إم ، ، (1999)، الطريقة الأساسية لتحليل البيانات، باريس، آيرولز .

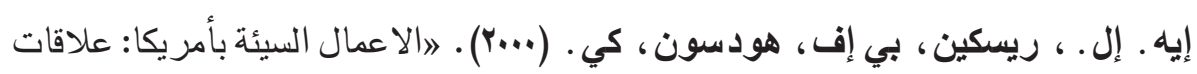

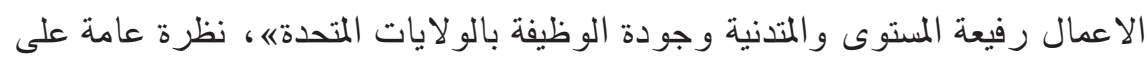

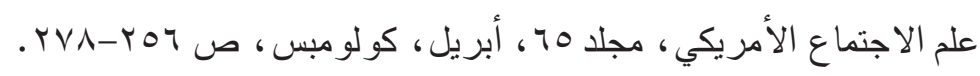

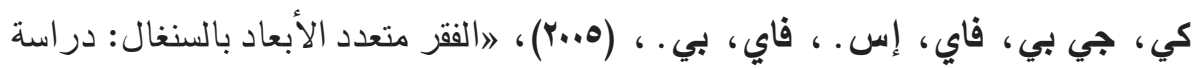

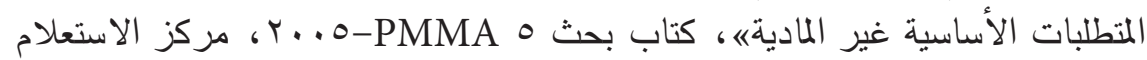

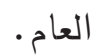

كراهن، هارفي، (1999) . "جودة العمل بالخدماته، سجل مسح المجموعات الاجتماعية

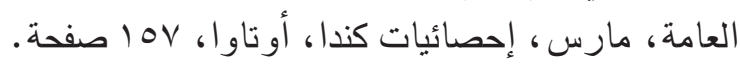

ليبارت، إل. ، مورينيو، إيه. ، بيرون، إم. (1990)، إحصائيات استكثافية متعددة

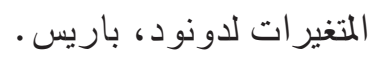




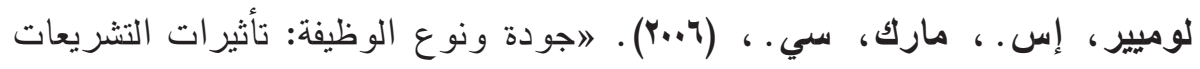

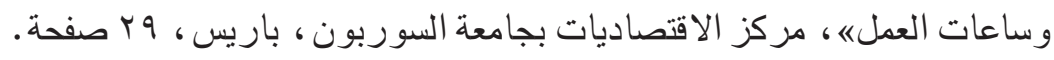

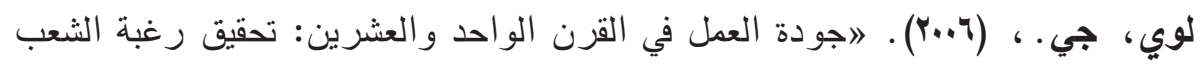

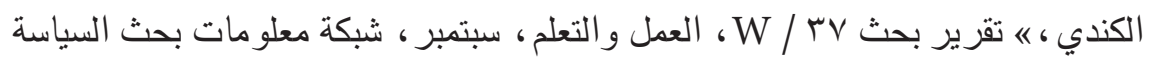

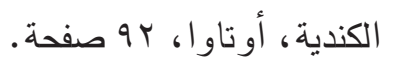

ماك جوفيرن، باتريك، اسميتون، دييوراه، هيل، استيفن، (ع..بr). 》الاعمال السيئة

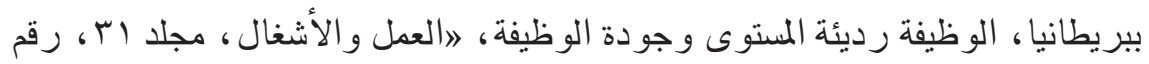

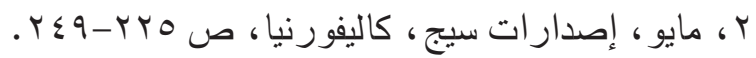

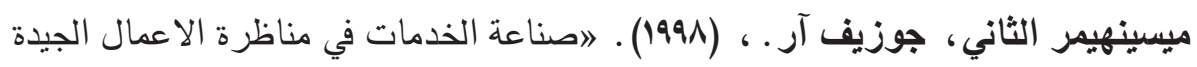

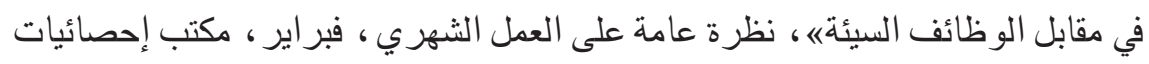

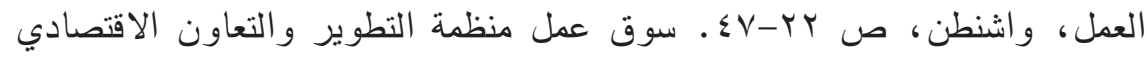
و المقالات العرضية للسياسة الاجتماعية رقم عب، أغسطس ، باريس ، بـ كـ صفحة.

منظمة التطوير والتعاون الاقتصادي (1..r) . هالعمل بمنظمة التطوير و التعاون الاقتصادي

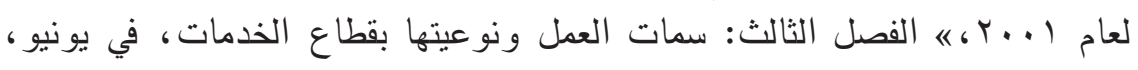

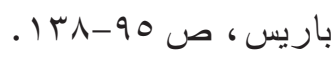

بي ألبيرن، إم إن، سيتي، إف. ، تيرازا، إم. (ه...r)، اققياس الفقر متعدد الأبعاد

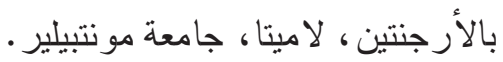

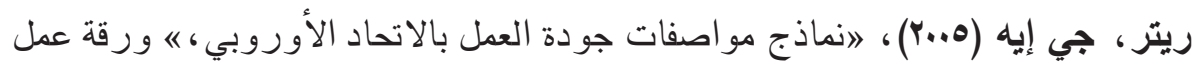

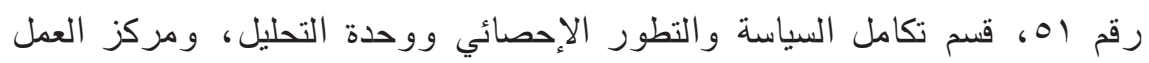

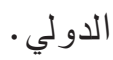

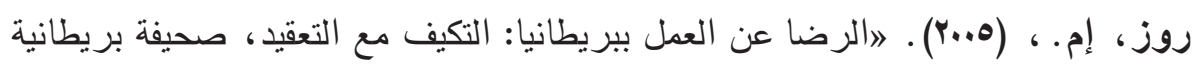

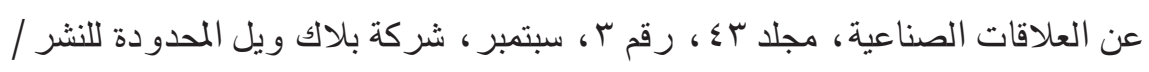

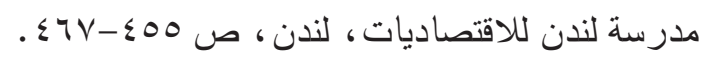


سيلقين جيه. (^..ب) ، (المؤشر ات التكاملية لمعدل البطالةه، إحصائيات المعلومات القومية، إيروستات

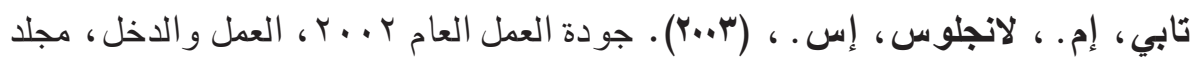

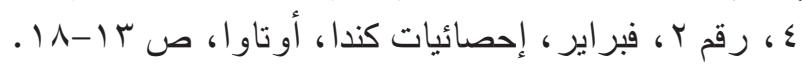

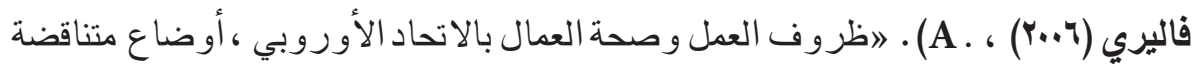
حسب أشكال التنظيمه في نوفمبر ، مركز در اسة التوظيف، آيل بفرنسا حـ صفحة.

فولي، إم. (·191). تحليل البيانات، الاقتصاديات، باريس.

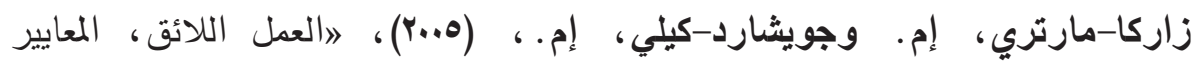
و المؤشر اته، ورقة عمل رقم مه ه، التطور ومجموعة التحليلات الإحصائية.

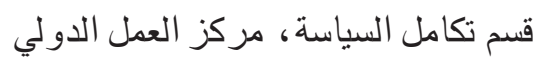

المطحقات

صندوق رقم ا: عرض مفصل لتحليل المراسلات المتثابهة المتتوعة صندوق رقم ا: عرض مفصل لتحليل المراسلات المتثابهة المتتوعة

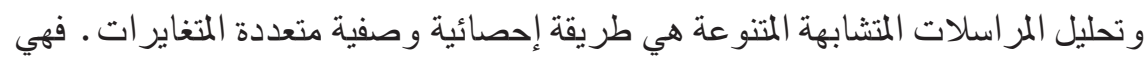

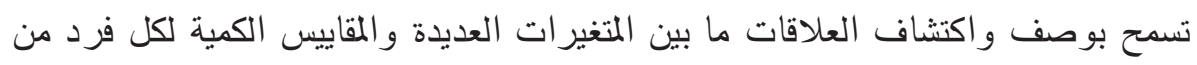

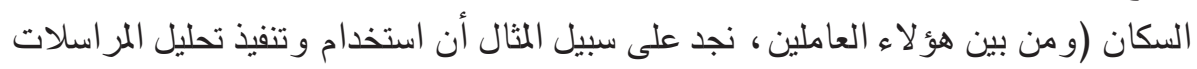

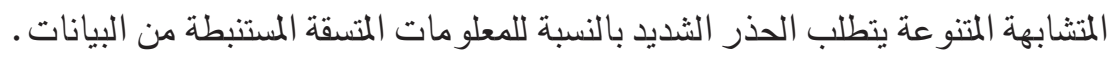

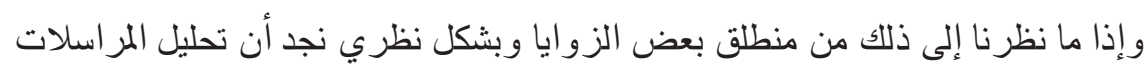

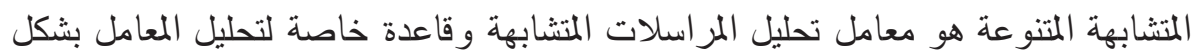

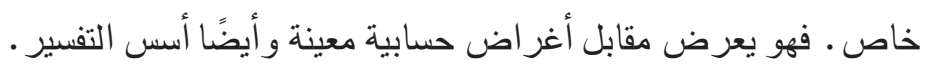


ولاءجر اء تحليل المر اسلات المتثابهة المتنو عة من المقترض أنه يو جد أفر اد N (مستخدمين

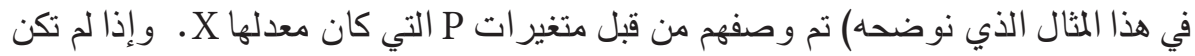

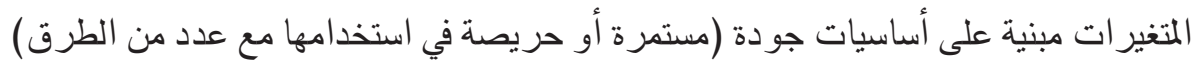

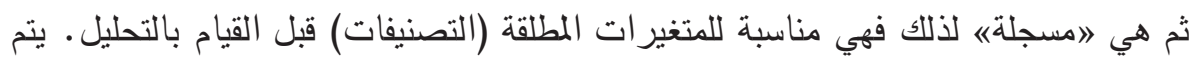

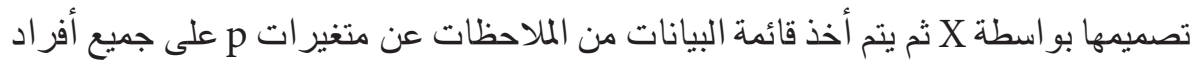

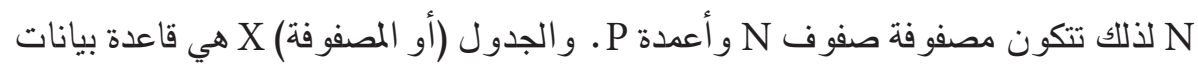
ACM

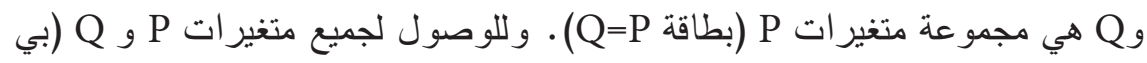

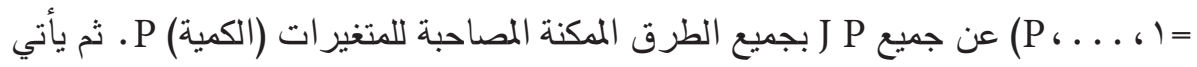
بعد ذلك اتحاد J لجميع المعادلات والمتغيرات أي أن بيانات X نقو بتعريف جدول جديد لها خصائص خاصة.

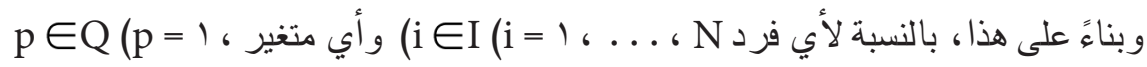

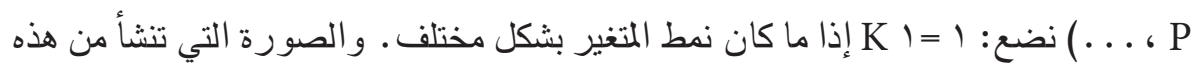
العملية و المعادلة العام (K

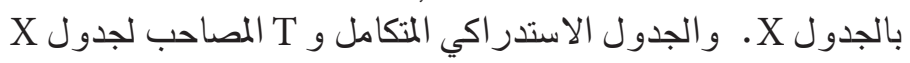
هو شكل مصفو فة .) و ويتم إقراره بشكل استدر اكي لأن المصطلحين ز وز اللذين من نفس المتغير يعتبر ان مقصور ين بشكل متبادل بالنسبة لكل فرد من

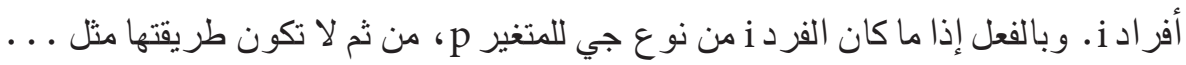

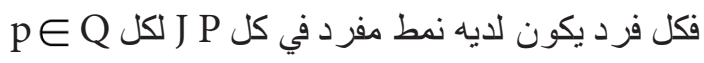

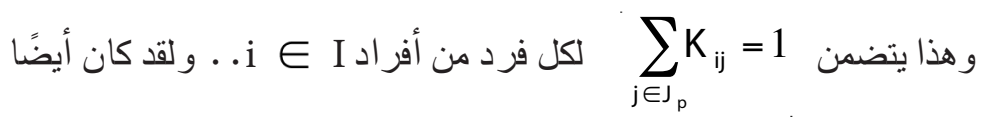
م وهو عدد المتغير ات في التحليل (خط و احد لعملية الحساب) $\sum_{p \in Q} \sum_{j \in J p} K_{i j}=\operatorname{Card}(Q)=P$ K 
التي هي عدد الأفر اد الذين لايهم نمط

$$
\forall p \in Q, \quad \sum_{j \in J_{p}} K_{j}=\operatorname{Card}(I)=N \text { وأيضًا }
$$

و هو إجمالي عدد الأفر اد (جميع الناشطين و العاملين والمختصين بالأمر ). عندما يصل في

$$
\sum_{j \in J} \sum_{i \in I} K_{i j}=\sum_{j \in J} K_{j}=N \operatorname{Card}(Q)=N P . \quad \text { النهاية }
$$

وهي عملية الحساب عن كل من (متغير ات) لأفر اد N . إضافة إلى جداول X و T (CCT) ،

$$
(\mathrm{K}, \mathrm{K})=\left(\sum_{\mathrm{p} \in \mathrm{Q}} \operatorname{Card}\left(\mathrm{J}_{\mathrm{p}}\right), \sum_{\mathrm{p} \in \mathrm{Q}} \operatorname{Card}\left(\mathrm{J}_{\mathrm{p}}\right)\right) \text { وعمل مصفو فة المنتج }
$$

حصلنا على ما يسمى بجدول بيرت . و تعد B جدول احتمالية متنوعة تعمل على تقاطع اثنين

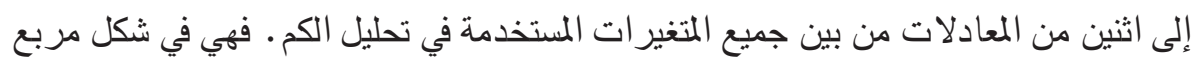

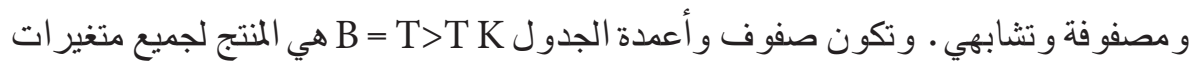

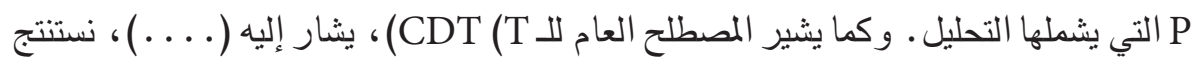

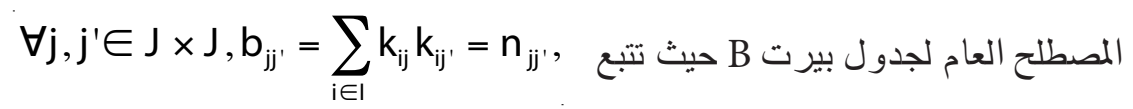

الذي هو عدد الأفراد جميعهم في وقت واحد والمصطلحين ز وز . وأيضًا من التركيب الاستدر اكي لا T الذي من المككن أن يستدل عليه:

$\forall p \in Q, \forall j, j^{\prime} \in J_{p} \times J_{p}, b_{j j}=0$ if $j \neq j^{\prime}$.

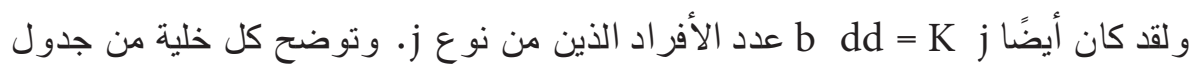

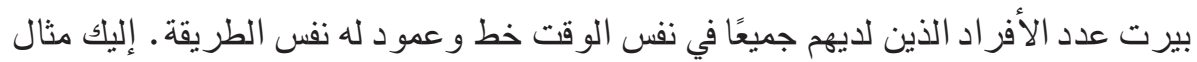

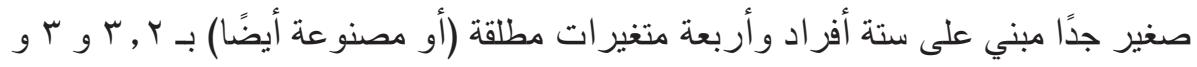

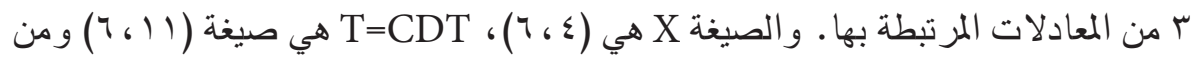
حجم 11 (B) 11 (B) 11 (لمعادلات المتب 


$$
T=\left\{\begin{array}{lllllllllll}
1 & 0 & 0 & 0 & 1 & 0 & 0 & 1 & 1 & 0 & 0 \\
0 & 1 & 0 & 1 & 0 & 1 & 0 & 0 & 1 & 0 & 0 \\
0 & 1 & 0 & 0 & 1 & 0 & 1 & 0 & 0 & 1 & 0 \\
0 & 0 & 1 & 0 & 1 & 1 & 0 & 0 & 0 & 0 & 1 \\
0 & 0 & 1 & 1 & 0 & 0 & 1 & 0 & 0 & 0 & 1 \\
0 & 1 & 0 & 1 & 0 & 0 & 0 & 1 & 0 & 0 & 1
\end{array}\right) \quad X=\left(\begin{array}{llll}
1 & 2 & 3 & 1 \\
2 & 1 & 1 & 1 \\
2 & 2 & 2 & 2 \\
3 & 2 & 1 & 2 \\
3 & 1 & 2 & 3 \\
2 & 1 & 3 & 3
\end{array}\right)
$$

$$
B=T T=\left(\begin{array}{lllllllllll}
1 & & & & & & & & & & \\
0 & 3 & & & & & & & & \\
0 & 0 & 2 & & & & & & & \\
0 & 2 & 1 & 3 & & & & & & & \\
1 & 1 & 1 & 0 & 3 & & & & & & \\
0 & 1 & 1 & 1 & 1 & 2 & & & & & \\
0 & 1 & 1 & 1 & 1 & 0 & 2 & & & & \\
1 & 1 & 0 & 1 & 1 & 0 & 0 & 2 & & \\
1 & 1 & 0 & 1 & 1 & 1 & 0 & 1 & 2 & \\
0 & 1 & 0 & 0 & 1 & 0 & 1 & 0 & 0 & 1 & \\
0 & 1 & 2 & 2 & 1 & 1 & 1 & 1 & 0 & 0 & 3
\end{array}\right)
$$

و على المستوى الإحصائي (الحسابي) ، تعد الـACM امتدادًا لمعامل تحليل الرسائل المتثابهة

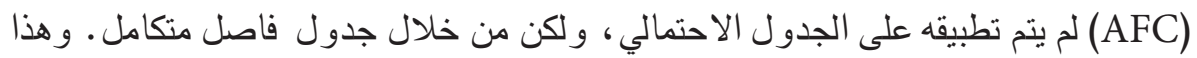

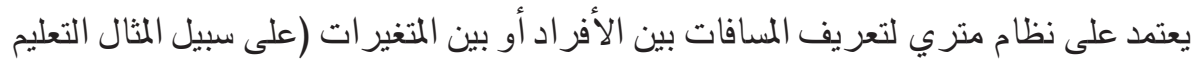

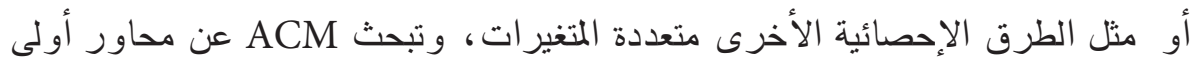

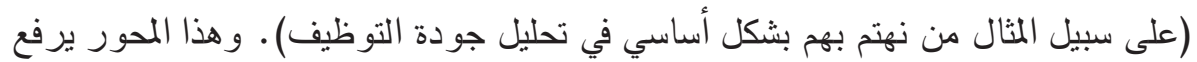

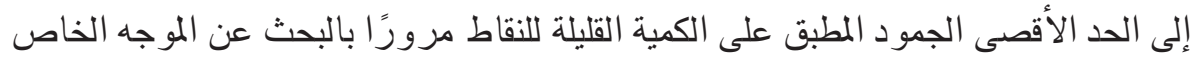

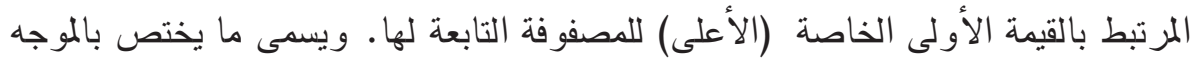

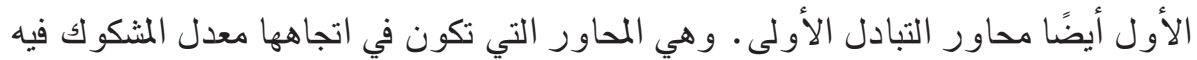

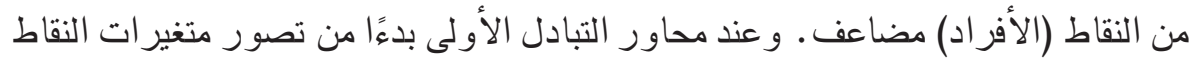

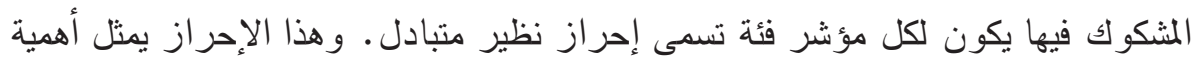

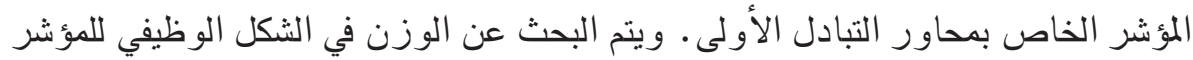

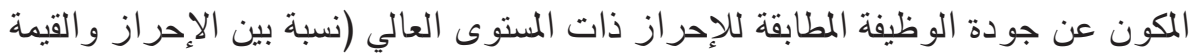
النسبية للمحاور) • وفي التدريب العملي، كل فرد يتم تمثيله بواسطة خط موجه (1) (K). 
و لتكن D هي المصفوفة الفطرية التي تتكون من العناصر الفطرية لجدول B لبيرت . و ونوضح

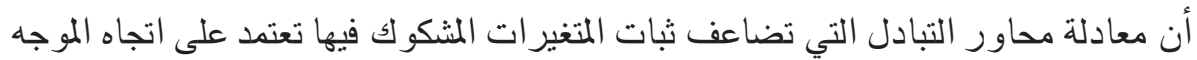

$$
\frac{1}{K} T^{\prime} T D^{-1} u_{\alpha}=\lambda_{\alpha} u_{\alpha}: \text { الذي يأتي من }
$$

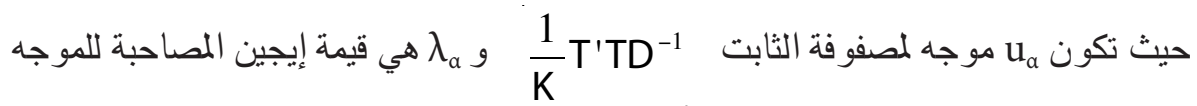

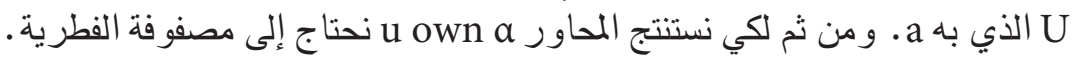

و وإن معادلة معامل $\quad \frac{1}{\mathrm{~K}} \mathrm{~T}^{\prime} \mathrm{TD}^{-1}$

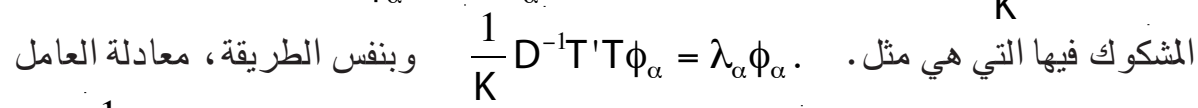
التي $\frac{1}{K} T^{-1} T^{\prime} F_{\alpha}=\lambda_{\alpha} F_{\alpha}$ a th fa تعطي على التوالي تفاصيل عن متغيرات العامل و الأفر اد. وتوضح أيضًا أن هناك علاقات

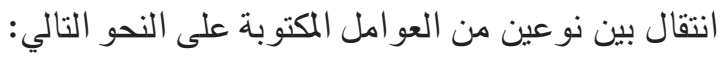

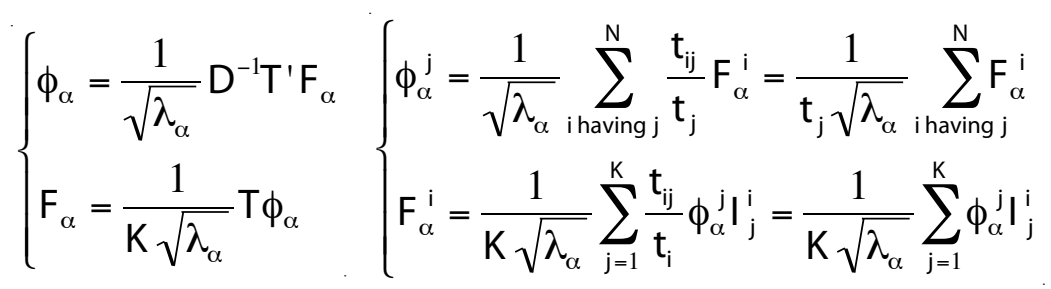

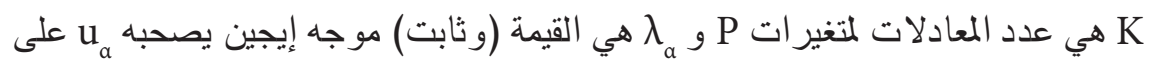

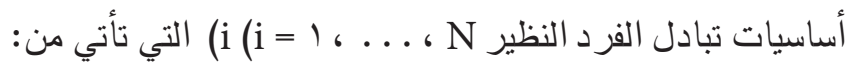

$$
\begin{aligned}
& F_{\alpha}{ }^{i}=\frac{1}{K \sqrt{\lambda_{\alpha}}} \sum_{j=1}^{K} \phi_{\alpha}^{j} I_{j}^{i} \cdot \phi_{\alpha}^{j}
\end{aligned}
$$

و هو إحر از الشكل · ، ز بشكل مختلف . و عندما ندقق في محاور التبادل الأولى (a=1) و نحصل

بدقة على IQE التي تم البحث عنها بهذا العمل:

$$
J Q I_{i}=F_{1}{ }^{i}=\frac{1}{K \sqrt{\lambda_{1}}} \sum_{j=1}^{K} \phi_{1}{ }^{j} I_{j}^{i}=\frac{1}{K} \sum_{j=1}^{K} W_{j} I_{j}^{i} \text {. }
$$

في التعبير الأخير الذي أوضحناه . بو اسطة تعريف IQE 
المحاور الأولى لتحليل الرسائل المتشابهة المتنوعة التي أجريناها هنا. هذا المؤشر (أو عكسه)

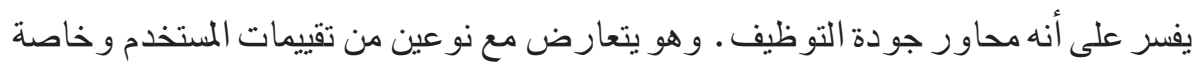

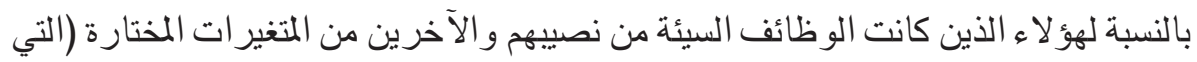

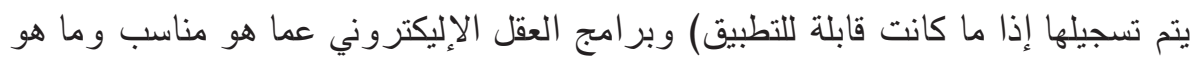

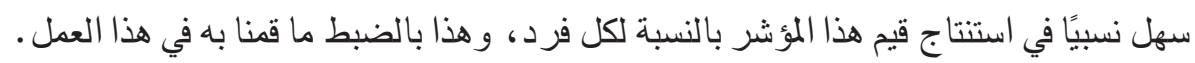

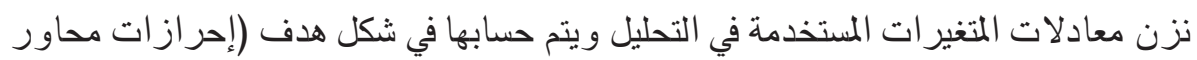

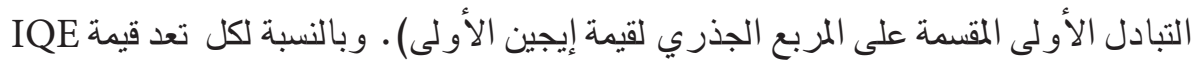

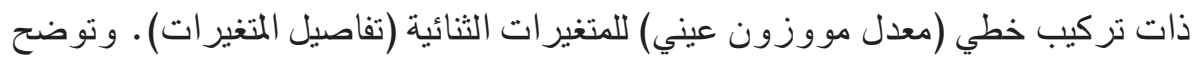

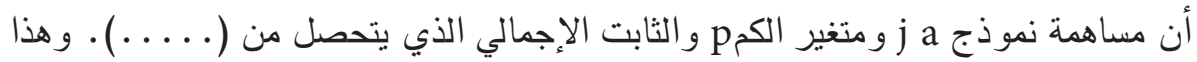

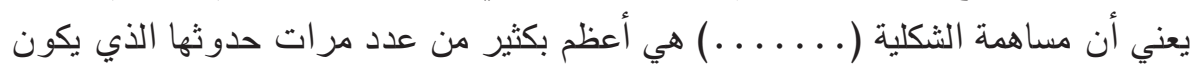

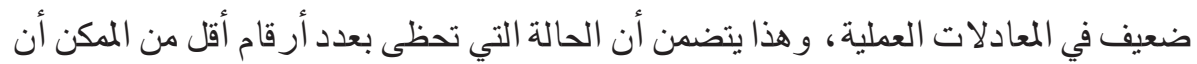

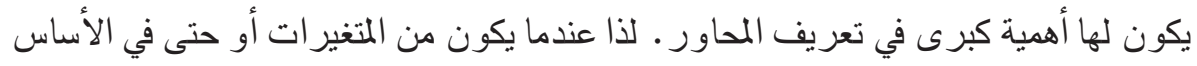

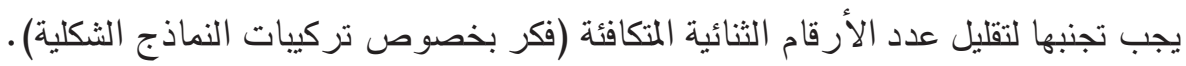
و إضافة إلى ذلك، تتأتى مساهمة متغاير الكم . C من المثكوك فيه على النحو التالي: ز $\in$ هو عدد المعادلات للمتغير • و ومن ثم يكون مساهمة

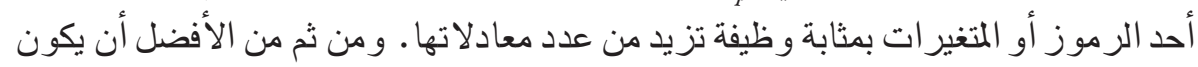
لديك نفس عدد المعادلات (أو على الأقل لا يكون هناك تبائنًا و اسعًا بهذا المستوى) .

وفيما يتعلق بهذا، من المهم أيضًا أن يكون لديك طرقًا مختلفة عن بعضها بعضًا بالنسبة لمستوى كل متغير متبقي وهي تختلف بثدة في معادلات الأفراد في مقابل التوظيف. و النماذج الثكلية القريبة جدًا في الحقيقة تعمل على تعقيد تفسير النتائج و السجلات البيانية

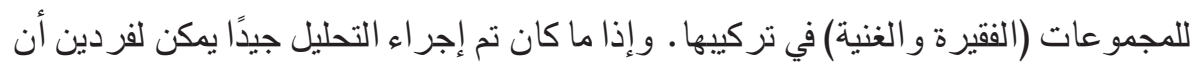

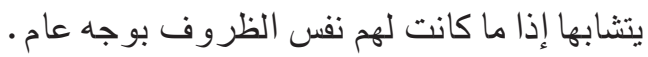

ومن المكن أن يقدمو انتائج متقاربة عن WQI و العكس بالعكس. ومن الناحية

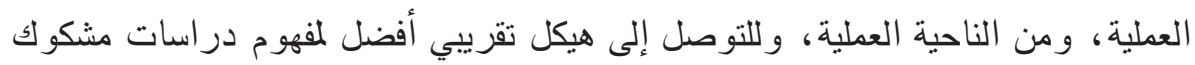

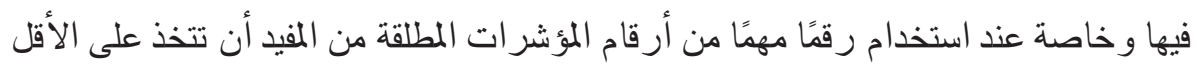

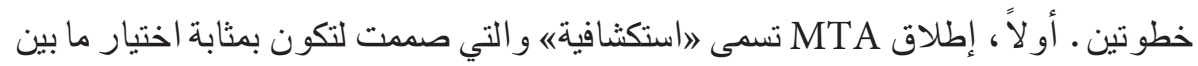


المتغيرات الأساسية ولإسقاط التي ليس في إمكانها التمييز بين الأفر اد على أساس دراسة ما

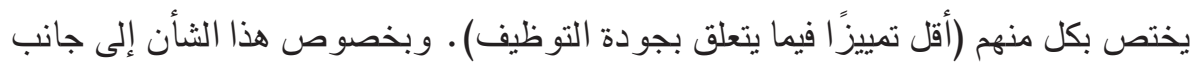

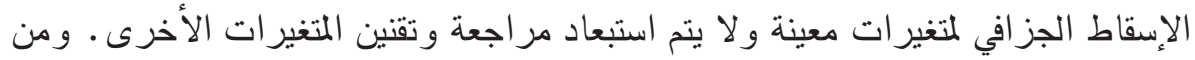

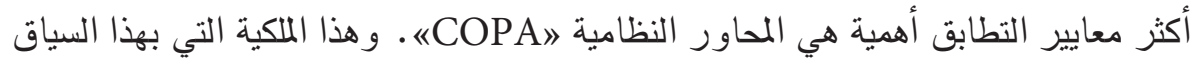

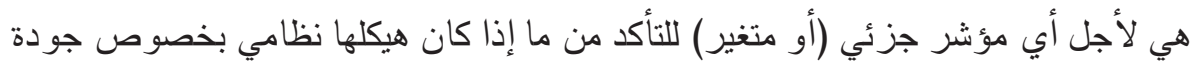

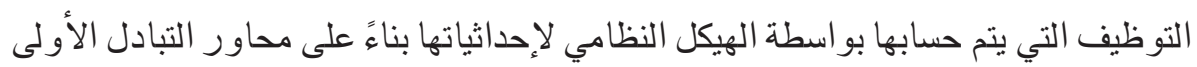
WWQI»

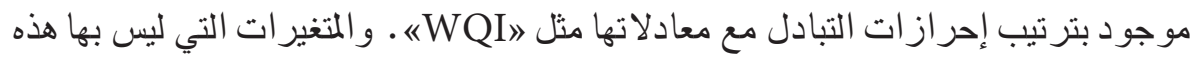

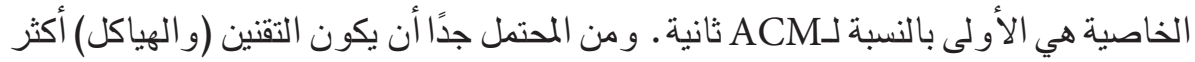

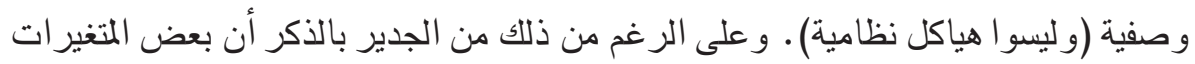

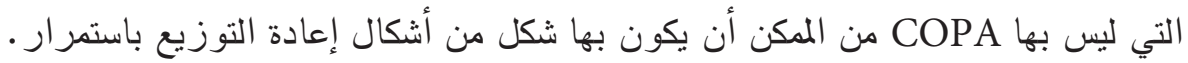

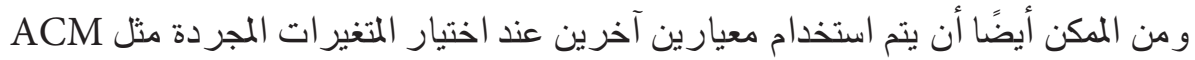

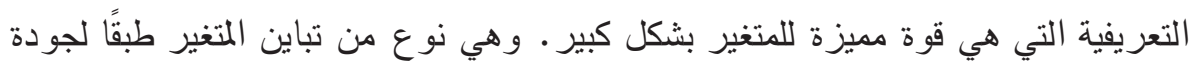

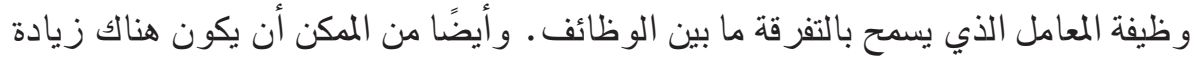

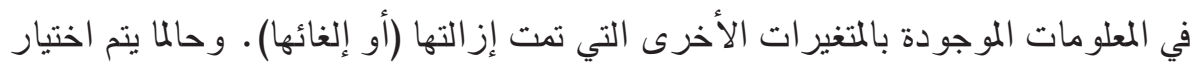

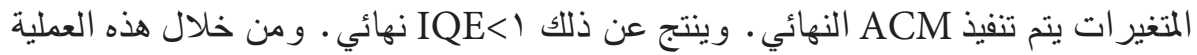

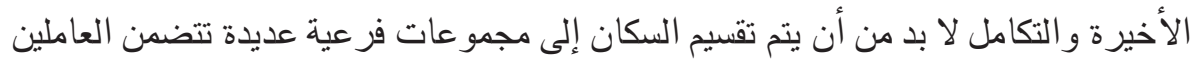

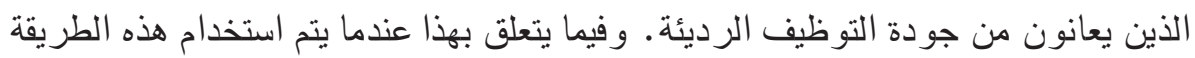

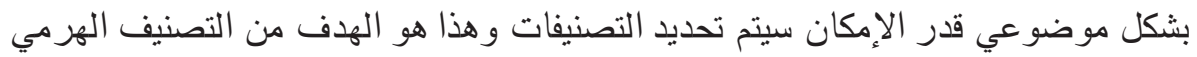
التصاعدي. 
جدول ا: معدلات أنظة الخصومات المتفيرة من المعاملات المحورية الرئيسية

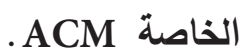

\begin{tabular}{|c|c|c|c|}
\hline \multicolumn{3}{|c|}{ العوامل } & \multirow{2}{*}{ المتغيرات/ الأنظمة } \\
\hline العامل 3 & العامل 2 & العاهل 1 & \\
\hline \multicolumn{4}{|c|}{ مدة العمل (ساعة/ الأسبوع) } \\
\hline 0.2243019 & 0.0878605 & 0.0545141 & أقل من 20 \\
\hline 0.1067214 & 0.0003589 & -0.295521 & ما بين 20 إلى 40 \\
\hline-0.0500277 & -0.0891213 & 0.0198635 & ما بين 40 إلى 56 \\
\hline-0.1016394 & 0.0741211 & 0.205618 & أكثر من 56 \\
\hline \multicolumn{4}{|c|}{ نظام التوظيف } \\
\hline-0.199349 & -0.0127438 & -0.0256822 & وقت كلي \\
\hline 0.448519 & 0.6040631 & 0.3283071 & وقت جزئي \\
\hline 0.174043 & -0.2731851 & 0.5285862 & المناسبات \\
\hline 0.2293997 & -0.1369075 & 0.47548 & أخرى \\
\hline \multicolumn{4}{|c|}{ عقد العمل } \\
\hline 0.1173583 & -0.0254063 & -0.6390197 & CDI \\
\hline 0.0810729 & -0.1158676 & -0.4424278 & CDD \\
\hline-0.0681842 & -0.2198175 & 0.0709849 & شفوي أو ما شابه \\
\hline 0.0221685 & 0.3208174 & 0.2862132 & أخرى \\
\hline \multicolumn{4}{|c|}{ الترقي الوظيفي (شهريا) } \\
\hline-0.009818 & -0.0403964 & 0.2242678 & أقل من 36 \\
\hline-0.00737 & -0.0385847 & 0.0528356 & ما بين 36 إلى 96 \\
\hline 0.018376 & 0.0026839 & -0.1071196 & ما بين 96 إلى 210 \\
\hline-0.001308 & 0.0919397 & -0.2056308 & أكثر من 210 \\
\hline \multicolumn{4}{|c|}{ تغيير الوظيفة } \\
\hline 0.1948956 & -0.3079722 & 0.4596423 & الرغبة في التغيير \\
\hline-0.0499271 & 0.079138 & -0.1181119 & عدم الرغبة في التغيير \\
\hline \multicolumn{4}{|c|}{ البحث عن وظيفة } \\
\hline 0.1936106 & -0.3193319 & 0.4685107 & 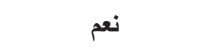 \\
\hline 0.1952743 & -0.291742 & 0.4469713 & ע \\
\hline-0.0499271 & 0.079138 & -0.1181119 & غير مهتم \\
\hline
\end{tabular}




\begin{tabular}{|c|c|c|c|}
\hline \multicolumn{4}{|c|}{ ممارسة وظائف ثانوية } \\
\hline 0.3525192 & 0.2534053 & 0.1323998 & 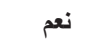 \\
\hline-0.0040167 & -0.0028874 & -0.0015086 & ע \\
\hline \multicolumn{4}{|c|}{ ترك العمل } \\
\hline 0.0666943 & -0.0650197 & -0.536725 & 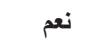 \\
\hline-0.9812153 & -0.2491851 & 0.2077429 & ل \\
\hline 0.0221843 & 0.321254 & 0.287026 & غير مهتم \\
\hline \multicolumn{4}{|c|}{ الأمن الاجتماعي } \\
\hline 0.0663649 & -0.0577367 & -0.5426085 & 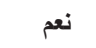 \\
\hline-0.0271522 & 0.0236221 & 0.222 & ע \\
\hline \multicolumn{4}{|c|}{ مكان النشاط } \\
\hline-0.0154947 & -0.0229576 & -0.117823 & محلي \\
\hline 0.2518996 & 0.4571316 & 0.3216047 & منزلي \\
\hline-0.0046962 & -0.0017227 & 0.3945185 & 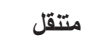 \\
\hline 0.0101299 & -0.3233376 & 0.350819 & أخرى \\
\hline
\end{tabular}


الثكل أا: سحب نقاط مؤشر جودة الوظيفة وتحليل العامل الخاص ب ACM

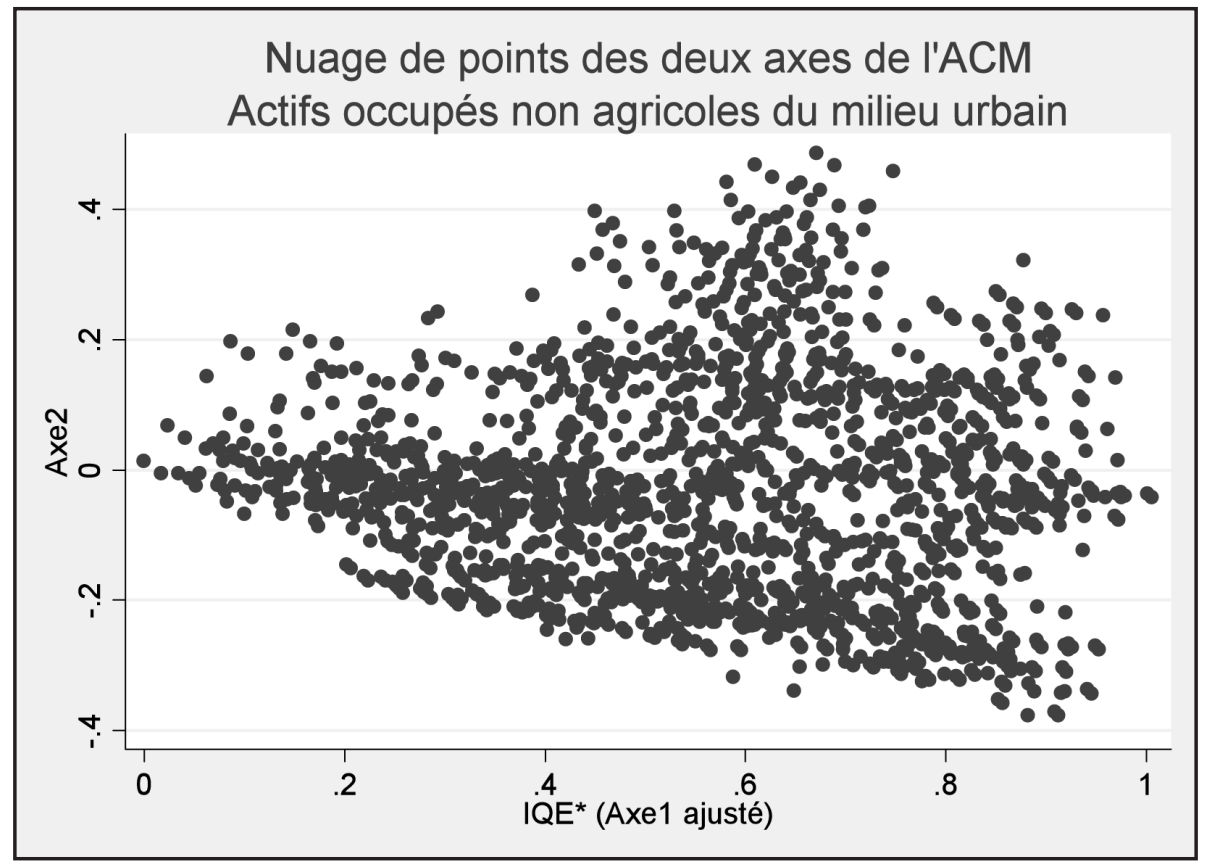

المصدر: إي إن إي 1999 
الثكل أب: شكل مستوى بعض المناطق والتصنيفات (ه مجموعات 9 الأفراد التي تثثل مناطق حضرية غير زراعية.

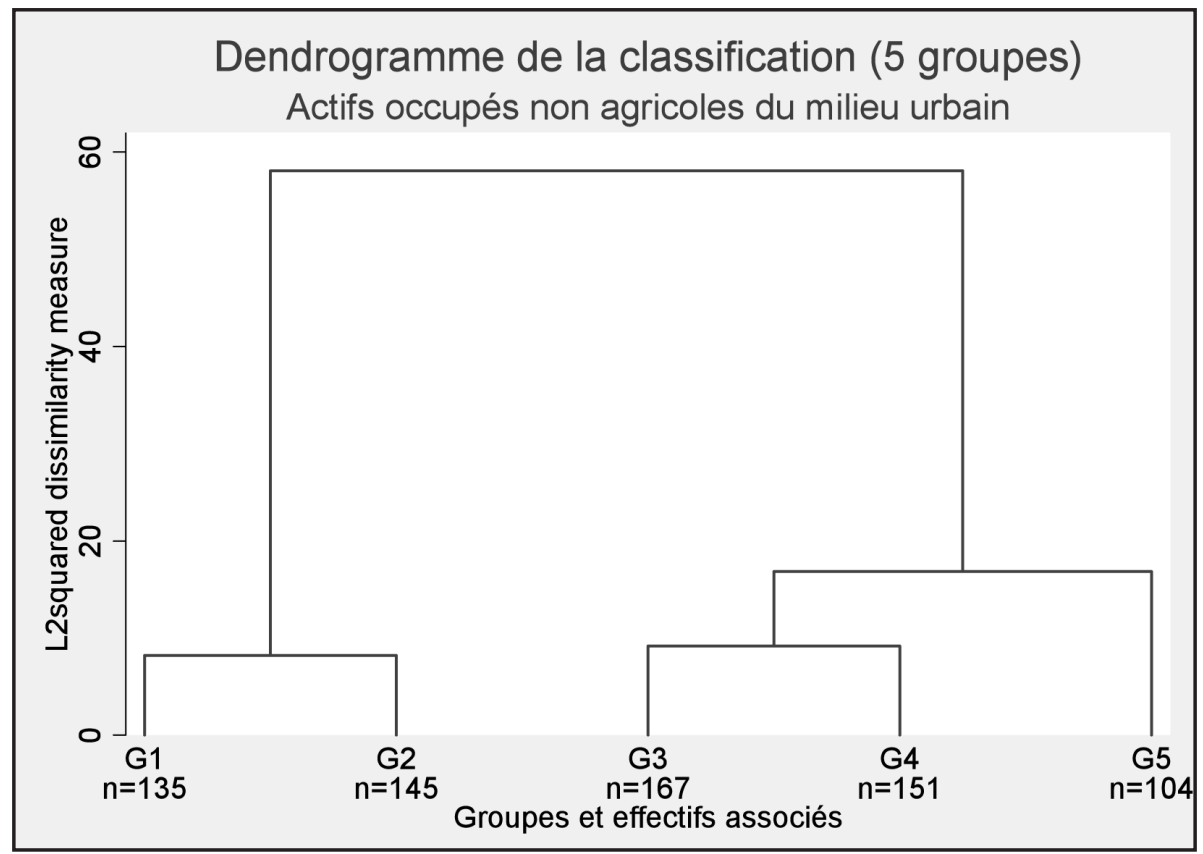


الثكل أب: شكل التصنيف (خمس مجموعات) الأفر اد اللأين يشظلون مناطق حضرية

غير زراعية.

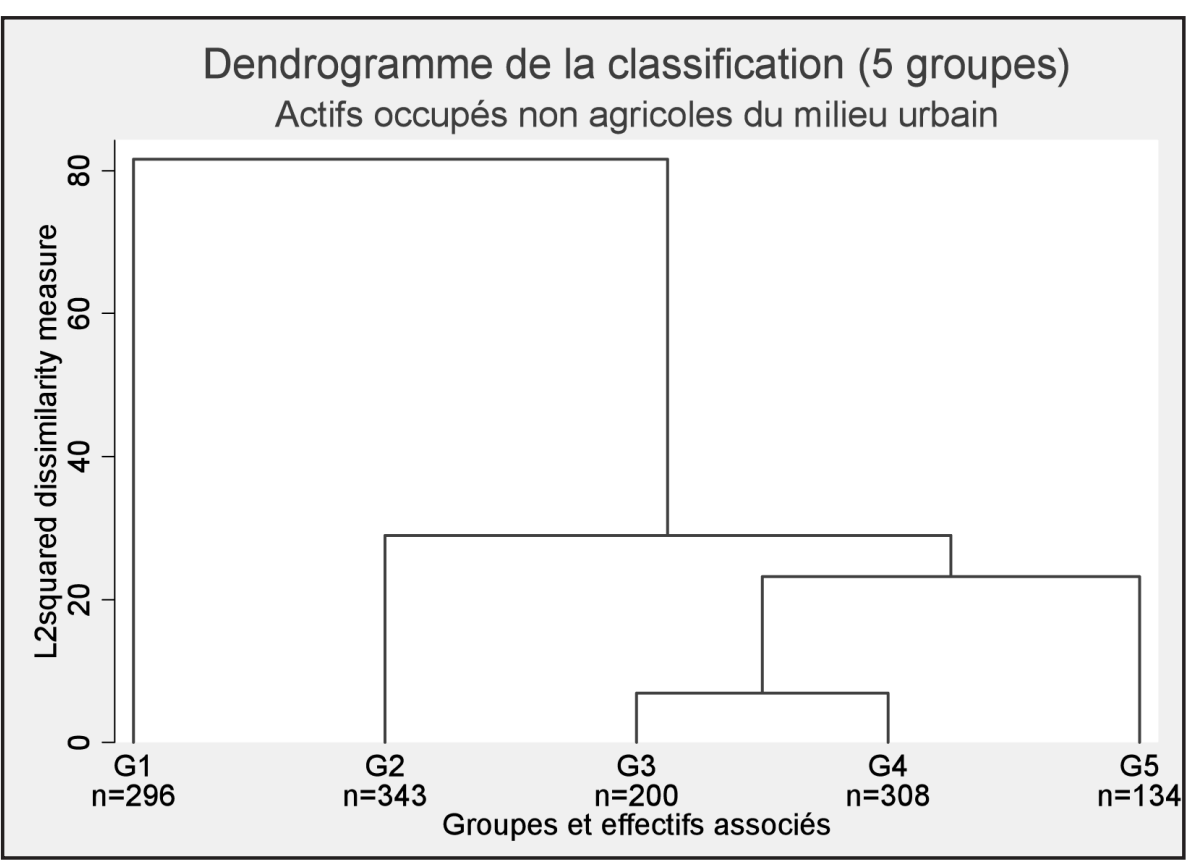

المصدر: إي إن إي 1999 
الثكل أ ؛: معدل مؤشر جودة الوظيفة على أساس المسئوليات والنوع معدل مؤشر

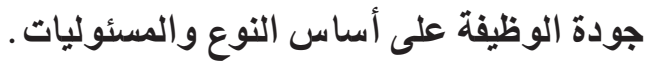

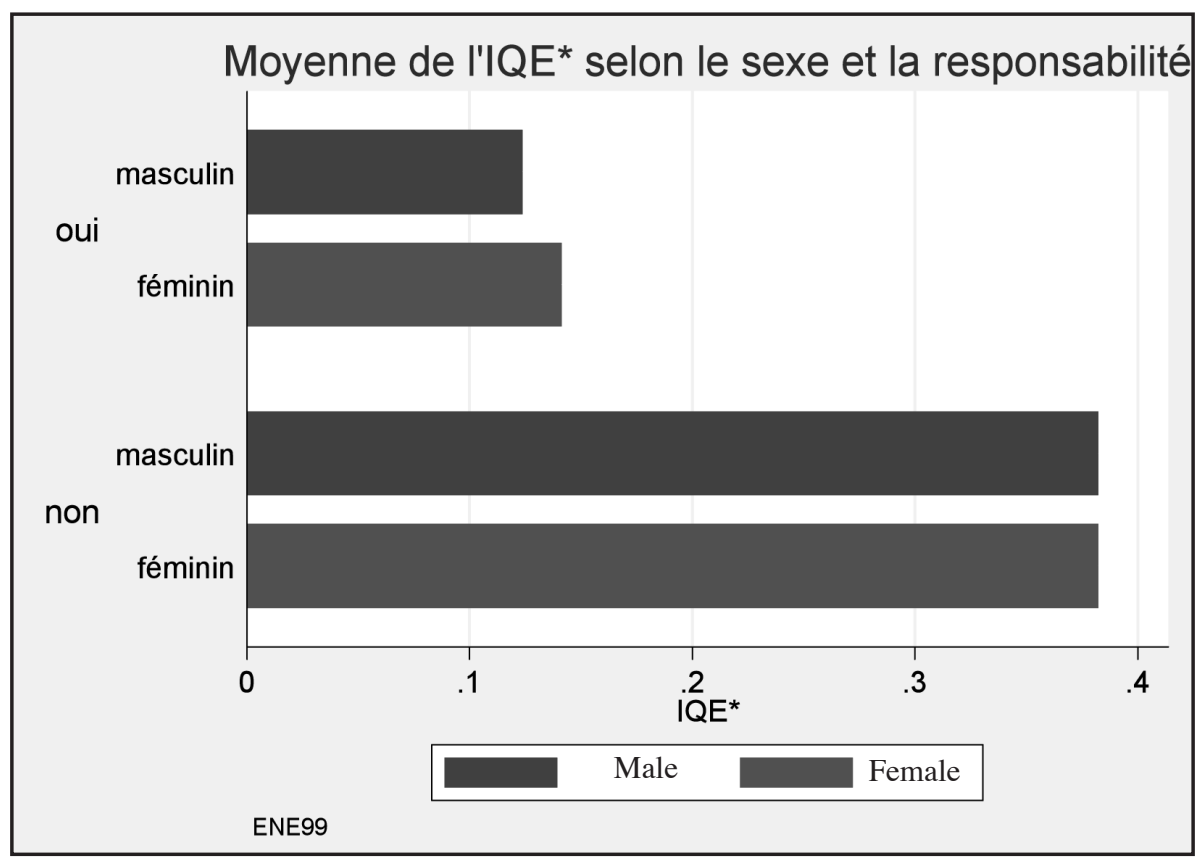

المصدر: إي إن إي 1999 


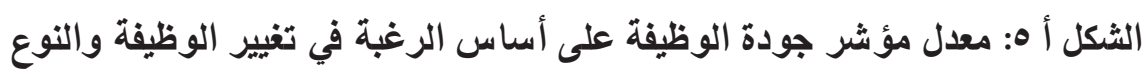
معدل مؤشر جودة الوظيفة على أساس النوع والرغبة في تغيير الوظيفة.

\section{Moyenne de l'IQE* selon le sexe et le désir de changer d'emploi}

masculin

oui

féminin

non

féminin

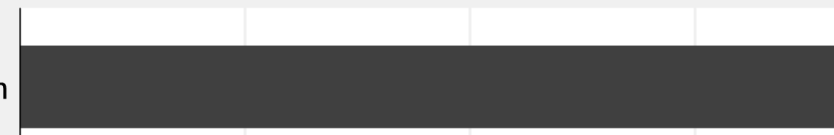

masculin

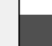

\section{(1)}

in
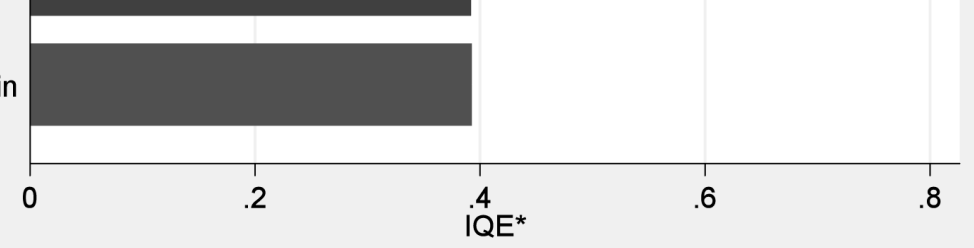

ENE99

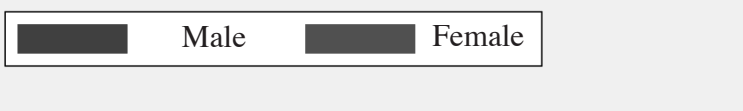

المصدر: إي إن إي 1999 


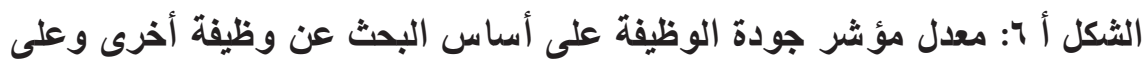

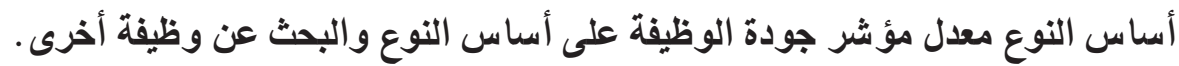

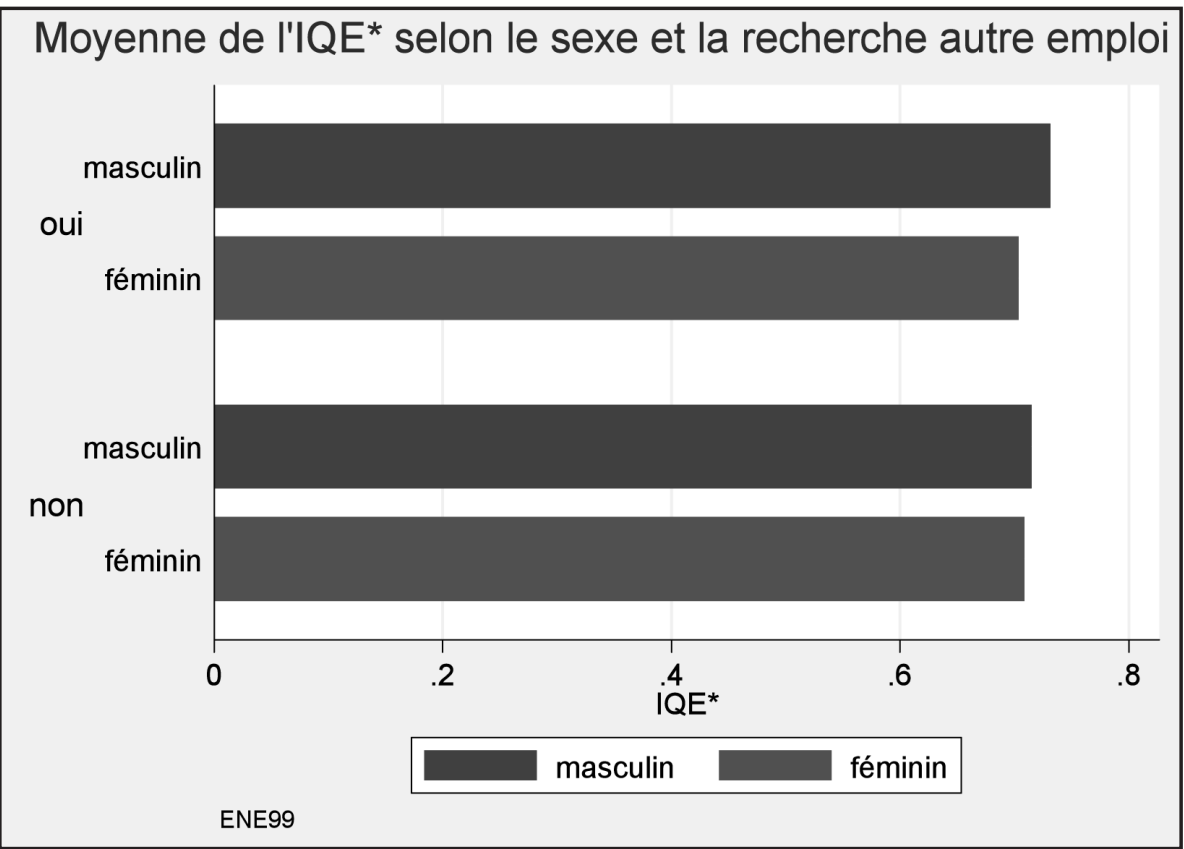

المصدر: إي إن إي 1999 
الثكل أ V: معدل مؤشرات جودة الوظيفة على أساس معدل المسئولية وعلى أساس

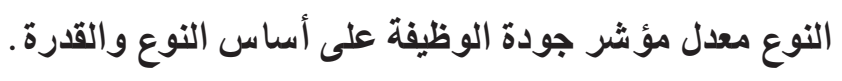

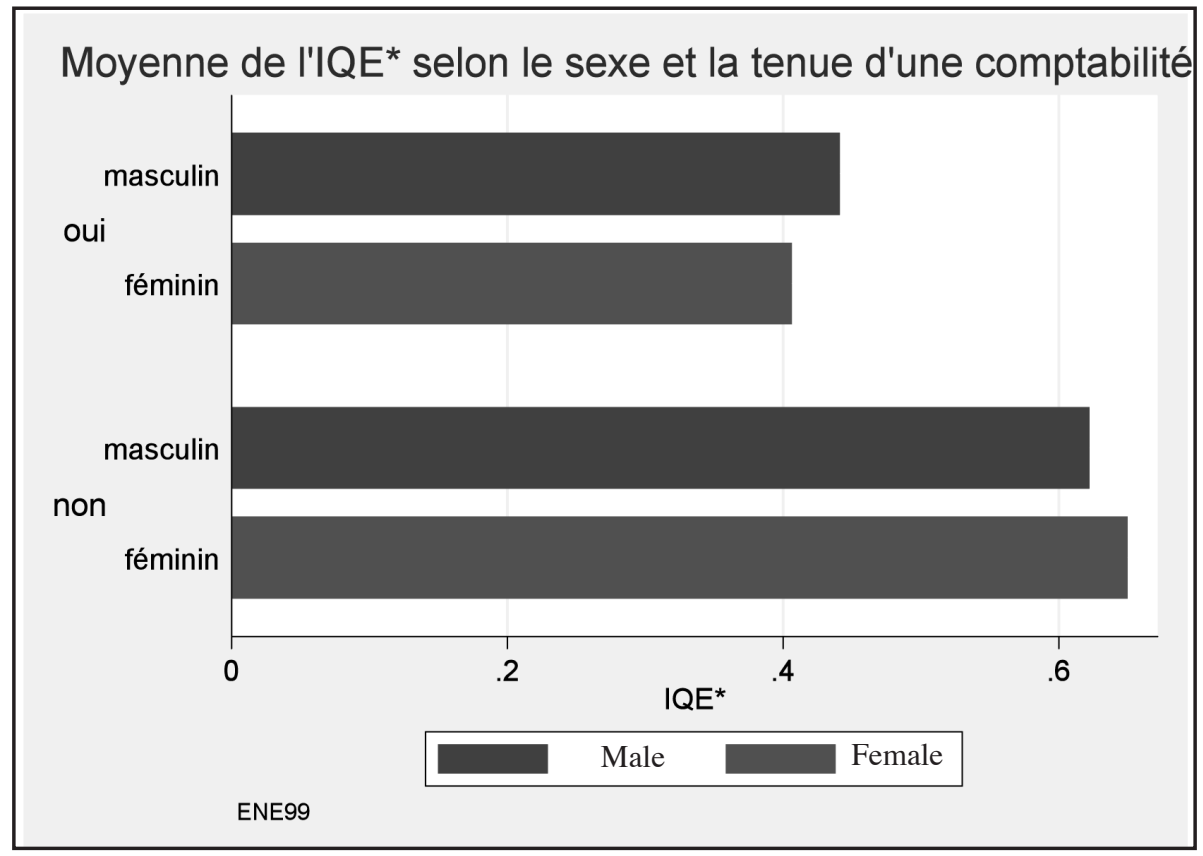

المصدر: إي إن إي 1999 
الثكل أه: معدل مؤشر جودة الوظيفة على أساس عدد الاحتمالات والنوع معدل

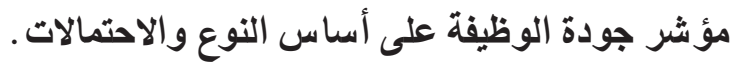

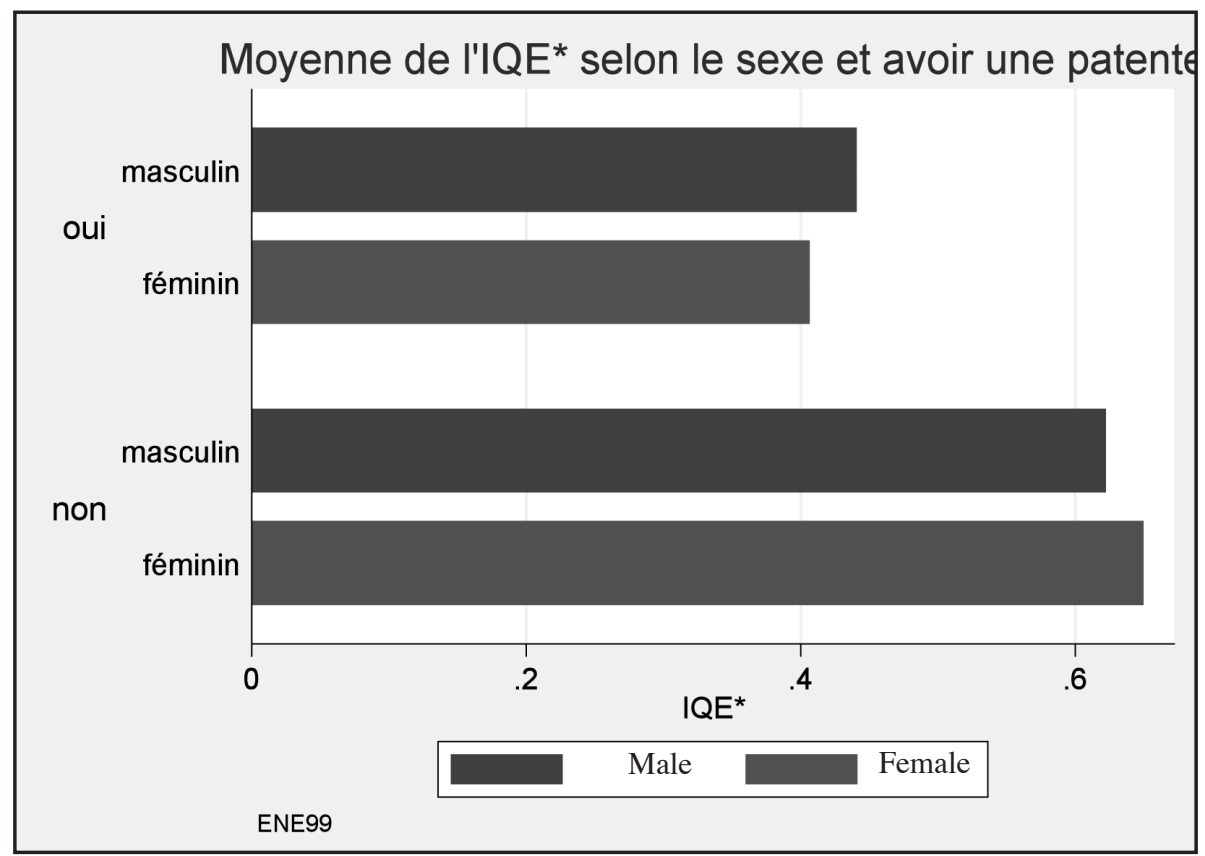

المصدر: إي إن إي 1999 
الثكل أ 9: معدل مؤشر جودة الوظيفة على أساس العصول على التأمين الاجتماعي

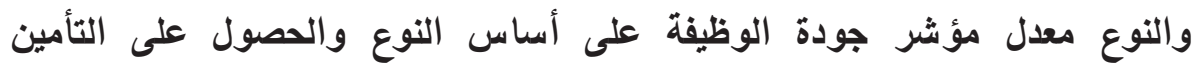
الاجتماعي.

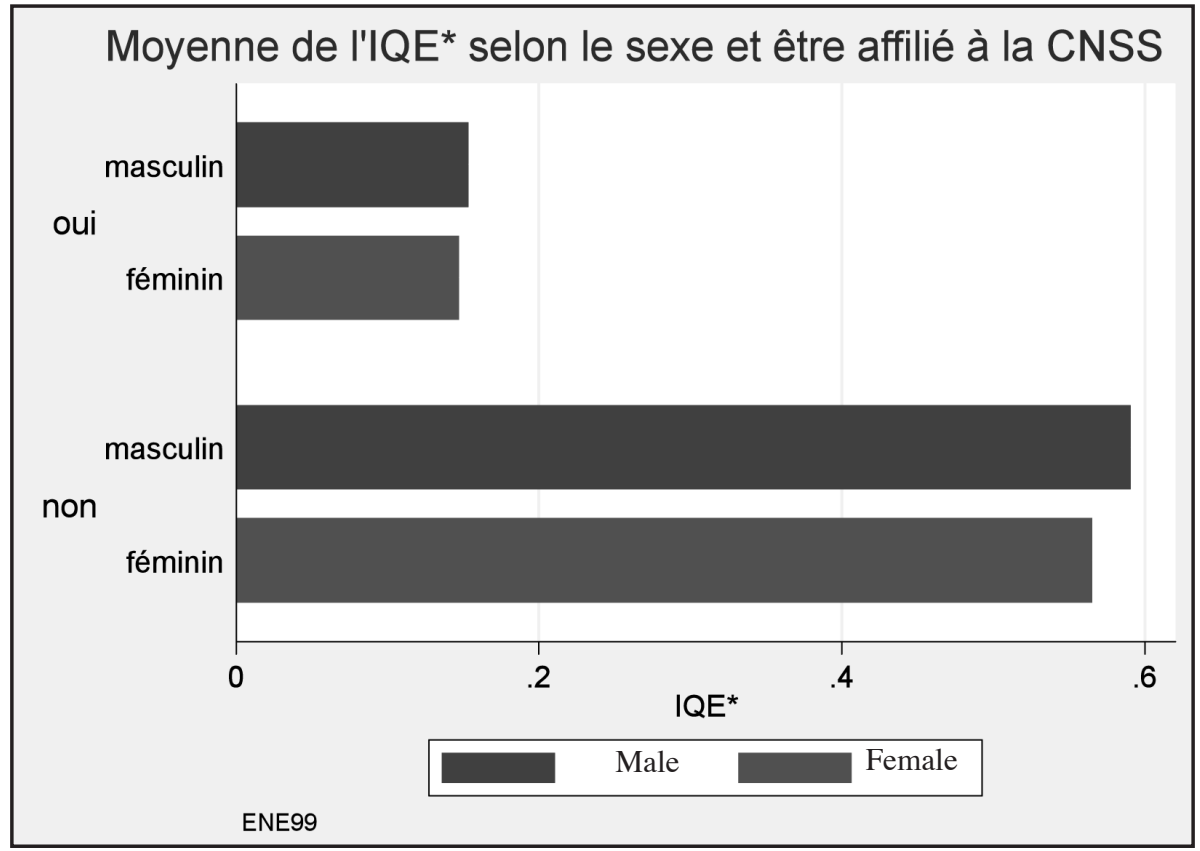

المصدر: إي إن إي 1999 
الثكل أ.1ا: معدل مؤشر جودة الوظيفة على أساس حجم المؤسسة وعلى أساس

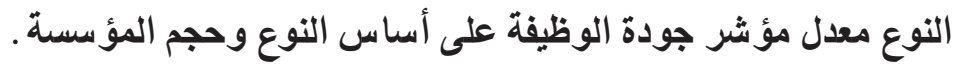
Moyenne de l'IQE* selon le sexe et la taille de l'établissement

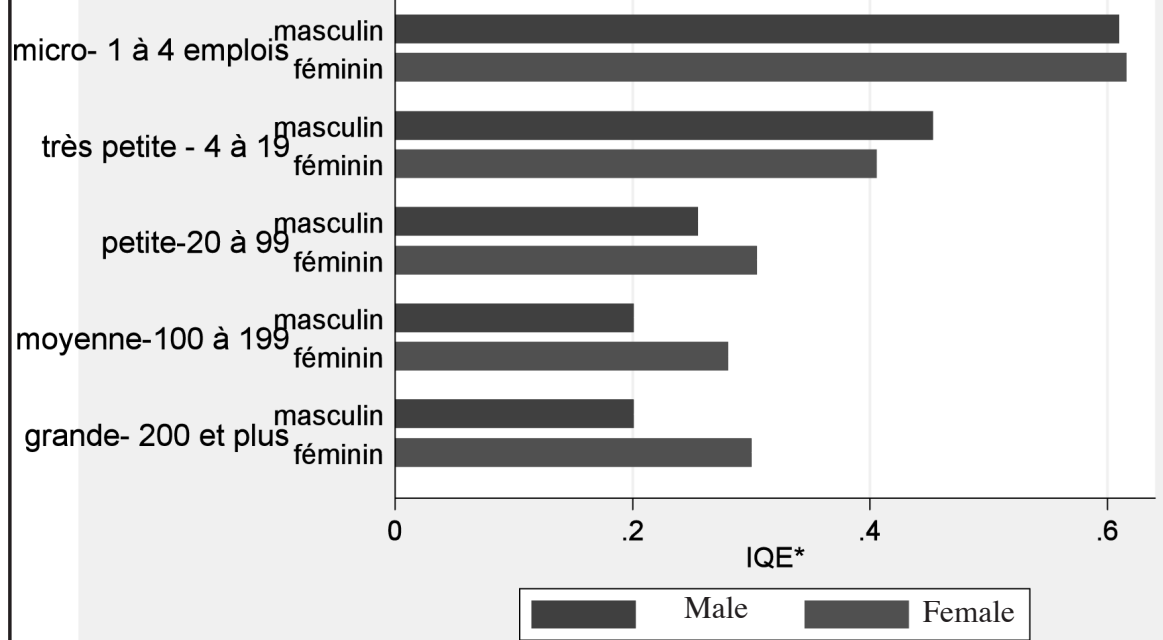

ENE99

المصدر: إي إن إي 1999 
